\title{
UC-NRLF
}

||||||||||||||||||||||||

+5 B 137 lat 



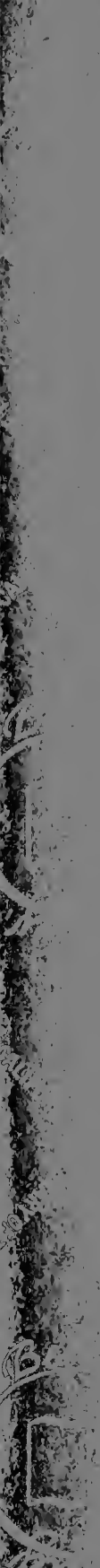





\title{
THE OLD NORSE ELEMENT IN SWEDISH ROMANTICISM
}

\author{
BY \\ ADOLPH BURNETT BENSON \\ SOMETIME FELLOW IN GERMAN, COLUMBIA UNIVERSITY
}

Submitted in Partial Fulfilment of the Requirements for the Degree of Doctor of Philosophy, in the Faculty of Philosophy, Columbia University

触战 侽ork

COLUMBIA UNIVERSITY PRESS

I9I4 
Copyright, I9I 4

By Columbia University Press

Printed from type, October, 1914

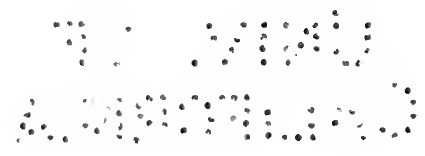


Approved for publication, on behalf of the Department of Germanic Languages and Literatures of Columbia University.

Calvin Thomas.

NeW YORK, October, 1914 
Digitized by the Internet Archive in 2007 with funding from Microsoft Corporation 
TO

\section{MY MOTHER}

WHOSE SACRIFICE AND ENCOURAGEMENT

HAS MADE MY EDUCATION POSSIBLE 



\section{PREFACE}

Enthusiasm for the Norse saga during the Swedish Romantic period was not confined to the members of the so-called Gothic School. The interest in the Viking age spread also to other groups of poets as well as to some individuals who, like Stagnelius, were not identified with any school. As we shall see, however, they were all, in the ordinary, broad sense, Romantic. This review, therefore, purports to deal with a number of heterogeneous writers, often belonging to entirely different literary confessions, but all bound together, for us, by a bond of common interest in Scandinavian antiquity.

The purpose of this study is fourfold: (I) to show clearly that a genuine interest in Scandinavian antiquity was present from the beginning in both the new literary tendencies of the time, (2) to characterize this interest, (3) to collect and examine all the important literary monuments from I8Io to about 1825 that make use of Scandinavian saga, and (4) to record conservative opposition to Norse mythology in Sweden during that period.

The well-known literary chiefs, Tegnér, Geijer, and Ling, will be treated only incidentally in this study, in connection with specific problems. The present investigation intends to emphasize the work of the minor "Goths" and of such other Romanticists as are not ordinarily. mentioned in connection with the Old Norse element. Among the latter are the Fosforists.

An appendix has been added, containing brief biographical data of the most important writers connected with Swedish Romanticism.

Lastly, I wish to express my gratitude to all those who have contributed in any way to make this investigation possible.

To Professor Calvin Thomas, first of all, I owe a deep debt for substantial encouragement and for ever-ready assistance, especially in connection with the final proof-reading. 
To Professor Robert Herndon Fife, Jr., of Wesleyan University, who introduced me to the study of Romanticism; to the late Professor Rudolf Tombo, Jr., to Professor Louis Auguste Loiseaux, and especially to Professor Arthur F. J. Remy, I owe more than a pupil's debt to a teacher.

To George Frederick Hummel, A.M., of Brooklyn, N. Y., I am indebted for a valuable suggestion in connection with the Introduction; Professor Fletcher Briggs of the Iowa State College of Agriculture and Mechanic Arts has furnished a useful hint; Fröken Elna Bengtson of Borås, Sweden, has provided a list of books for my bibliography; and Andrew Thomas Weaver, A.M., of Northwestern Academy, Hannah Senior Nicholson, B.A., and Marion E. Morton, B.A., recently of the Hanover (New Hampshire) High School, have assisted in correcting the manuscript.

I beg to acknowledge also my indebtedness to the Yale University library, where I obtained many of my most valuable sources.

July, I914.

A. B. B. 


\section{CONTENTS}

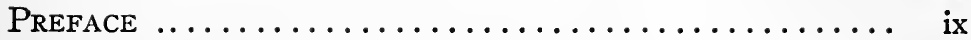

INTRODUCTION $\ldots \ldots \ldots \ldots \ldots \ldots \ldots \ldots \ldots \ldots \ldots \ldots \ldots \ldots$ I

Fosforism and Gothism.

The beginnings of interest in the Old Norse element.

The Northern renaissance in England, Germany, France, and

Denmark up to 18 ro, with list of important publications. The

Norse renaissance in Sweden during the seventeenth and eighteenth centuries.

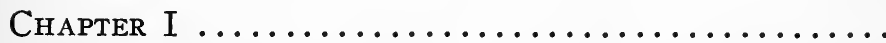

The interest of the Fosforists in Scandinavian Antiquity.

Atterbom: His Gothic contributions to Svensk LitteraturTidning.

The Fosforists in literary criticism.

Fosforos, Poetisk Kalender. Later interest in the saga.

Hammarskjöld: His attitude toward Norse myths, and interest in folklore.

Livijn: Early interest in Norse mythology.

The interest of various minor writers.

Chapter II

Non-Romantic interest in the Norse saga.

Granberg: "Jorund."

Charlotta Eleonora d'Albedyhll: "Gefion."

Chapter III

The theoretical problem of introducing Norse mythology into

Swedish art and poetry.

Foreign treatises on Norse mythology versus the Greek. Gräter,

Herder and Oehlenschläger.

Lectures on art by Hammarskjöld and Ling.

"Eddornas Sinnebildslära." Character of opposition to Norse myths.

Geijer warns against exaggeration in the use of Norse themes.

The exhibition of national art, 1818 . Tegnér's views.

xi 
Chapter IV ........................ 125

Erik Johan Stagnelius: The Old Norse element as a vehicle for Romanticism.

The Norse element in the epic "Blenda."

The mythical poem "Gunlög." The tragedies "Wisbur" and "Sigurd Ring." The fragment "Svegder."

Chapter V ......................... I 44

Nicander and Beskow, with special reference to the age of transition from Norse heathenism to Christianity, as reflected in the Romantic dramas of these two men.

"Runesvärdet." The Old Norse element in Oldur Silfverskägg. Influence of Fouqué and Oehlenschläger. Specific saga sources in "Runor af Norna-Gest."

Beskow "Hildegard," its Christian and pre-Christian elements. Comparison with "Runesvärdet." The viking type in "Hildegard."

Conclusion $\ldots \ldots \ldots \ldots \ldots \ldots \ldots \ldots \ldots \ldots \ldots \ldots \ldots \ldots$

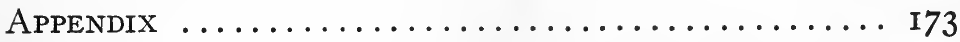

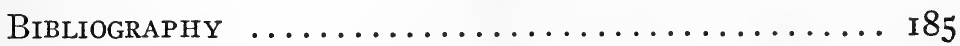

(1) For this study in particular. (2) For Swedish Romanticism in general. 


\section{INTRODUCTION}

\section{FosForism AND GOTHISM}

Den nordiska renässansen har lika djupa rötter som all annan europeisk romantik. Anton Blanck: "Den nordiska renässansen."

The term "Romanticism," in its broadest sense, is as vague in Sweden as elsewhere, and as a literary movement it is impossible to fix its boundary in time or to outline its program with any absolute precision. Nevertheless, beginning about I8Io, we can easily detect two main tendencies in Swedish Romanticism; one was called Fosforism, after the literary organ Fosforos, and the other we may call Gothism. The former looked to Greek, Spanish, Italian, and more especially to German models, while the so-called Gothic School aimed to have a more exclusively Scandinavian, i. e., "Gothic" character.

Both schools were, in a sense, national; both strove for originality and independence, opposed the correct, Gustavian, Academicians, and looked forward toward a new era in Swedish letters. The Fosforists lauded the work of their Swedish, as well as of their German, progenitors and brought many a hitherto obscure name into greater prominence. Of course the policies of both schools were reactionary; Fosforists and Goths alike were dissatisfied with existing conditions and pined for something new. But what they had in mind turned out to be the old-the medieval or the primitive. As in Germany and England, then, Swedish Romanticism was retrospective; but in Sweden medievalism was merely incidental or second-hand; more often the new pathfinders in Sweden went beyond the Middle Ages and studied early Oriental religion and philosophy; they sought for new interpretations of the ancient classics, or, like the Goths, they limited their attention to the Scandinavian countries and studied Norse mythology.

The principles of Fosforism had been in the making for at least a quarter of a century before they finally burst out into 
an open revolution about I8Io. The most obvious manifestations of the approaching storm were: an increasing interest in German and English literature, a growing hostility toward French models and frequent emphasis on feeling, originality, and imagination. The preceding century had been the age of enlightenment in Sweden and the dominating tone had been entirely French. The Academy of Belles-Lettres (VitterhetsAkademien), which had been founded by Queen Louise Ulrika in 1753 , had been reorganized and enlarged in I786 by Gustavus III., and was modeled after the French Academy. The Swedish capital, therefore, under the dictatorship of the Swedish Academy, continued to mold literature according to French rhetorical systems. In so doing, it undoubtedly performed a noble and necessary mission; it gave Swedish literature both style and form. But with the end of the French Revolution and the death of Gustavus III. in I792, many patriots began to feel that the French style had prevailed long enough; that it was getting a bit abstract, mechanical, and monotonous, and, therefore, undesirable.

One of the first to break with the French taste and to prepare the way for a new literary movement was Thomas Thorild (I759-1808). He was no creative artist, but an original thinker, who had a keen appreciation of life and art. In his controversy with the Academicians Leopold and Kellgren he gradually disabled the adherents of the Old School and anticipated the New by stirring up enthusiasm for Klopstock and Ossian. As a pupil of Rousseau, Thorild worshipped in him a "Romantic" favorite, who had escaped the fate of the other Frenchmen. Bengt Lidner (I757-1793), an irregular, Byronic type of poet, had already shown his skill in depicting strong passion and unbridled sentimental feeling. With marked ardency of expression and richness of invention he described the half-despairing sufferings of the human soul. ${ }^{1}$ Another of the eighteenth century poets, and the greatest of them all, to receive special recognition by the Romantic School was Karl Michael Bellman (I740-I795). He was thoroughly original, popular, and national. His bachanalian poetry showed great genius

1 Cf. L. Hammarskjöld: "Svenska vitterheten," 2d ed., pp. 402-3. 
and depth, and Hammarskjöld believed that this "Swedish Anacreon" had grasped the very essence of the Swedish national life. ${ }^{1}$

In the meantime, German and English authors were being read more and more, both in the original and in translation. An acquaintance with Gellert, Haller, Hagedorn, Hölty, Bürger, Jean Paul, Goethe or Schiller led to the study of Tieck, Novalis and the brothers Schlegel. "Werther" was translated into Swedish as early as I786; Klopstock's "Messias," I789-I792; Ossian, 1789-1794; translations of Young and Sterne had appeared by I790, and during the next two decades the German philosophers Kant, Fichte, and, more particularly, Schelling, rose rapidly in favor along with the younger group of German Romanticists. Calderon, Ariosto, Petrarch, Tasso, Dante, Rousseau, and Shakespeare receive considerable attention and the otherwise satirical and unfeeling Clas Livijn was moved to tears at the reading of "Wilhelm Meister." W. F. Palmblad, one of the charter members of the new school, likewise melted into tears at reading Lafontaine's novels and Kotzebue's dramas. $^{3}$

On October 7, 1807, a number of congenial souls, saturated with enthusiasm for German philosophy and the new German Romanticism, met in Uppsala and formed the society Musis Amici. It was really a "new edition" of a similar organization that had existed from I803-I806 called "Vitterhetens Vänner" or "Friends of Belles Lettres," and its leader was the seventeenyear-old Atterbom, of whom we shall have occasion to speak later. The following year the name of the society was changed to "Auroraförbundet" (a name which explains itself) and, as the members believed, a more definite outline of its program was drawn.up. The purpose of the Förbund was:

"in accordance with firm and eternal principles, gathered from Greek and German models, first to ennoble and develop the strength [of the Förbund], then to work energetically against the depraved taste [of the time], and finally, at least with a bright ray in the sky

1 Ibid., p. 342.

2 Cf. G. Frunck: Nya skolans förberedelser och första utveckling, p. I4.

3 Ibid., p. 39. 
of Swedish literature, to indicate the path of the approach of the sun."1

From now on we have a militant organization of Romanticists. With a sincere purpose, but in a somewhat vainglorious style, and often the most unscrupulous polemics, the new group set out to overthrow the old systems and to infuse the new Schelling-Tieck-Novalis spirit into Swedish letters.

Beginning with I8Io, for about a decade, there raged a feud between the literary conservatives and radicals, of such intensity and recklessness that it probably outstripped its German model in this respect. The Academicians, led by P. A. Wallmark, voiced their sentiments in the Journal för Litteraturen och Teatern (after 1813 called Allmänna Journalen) and the principal organs of the Auroraförbund were, in the order of their first appearance: Polyfem (from Polyphemus, the oneeyed giant who looks straight ahead); Fosforos (originally spelled "Phosphoros"); Poctisk Kalender; and Svensk Litteratur-Tidning. Much has been written on this interesting controversy. Suffice it to say here that, in aspiration, the radicals, now called Fosforists, were generally right; that both sides expended a wealth of energy and exhibited great wit in their polemics, but were often bitter and unjust in their method. Naturally the battle was most violent at the beginning, as in Polyfem; Fosforos adopted a less aggressive policy and aimed to show in original poems and reviews what Polyfem did in polemics. The chief characteristic of the Polyfem policy was a satirical, merciless attack on everything French and on everybody of French sympathies. Hence, the old, rationalistic school, the Swedish Academy, and its protégé, "the dry Boileau" Leopold, were criticized beyond all reason. No little talent was displayed in this struggle, however, and everyone will find that, for the most part, the polemics of the Fosforists are far more fascinating than their poems. ${ }^{2}$

Toward the end of the feud Tegnér, the sponsor of clearness,

1 Ibid., p. 32.

2 Rudolf Hjärne, in "Götiska förbundet," page 230, calls attention to the temporary confusion in the literary camp, brought about by the "blind self-confidence" of the Fosforists, and adds that their poetry "hovered between heaven and earth without belonging to either." 
attacked the vagueness of the Romantic theories, so that after I820 the Fosforistic S'chool had practically ceased to exist as a militant institution. But its ideas lived on in its efficient leader Atterbom, who, during the following decade, was destined to produce the work par excellence of this phase of Swedish Romanticism, namely, "The Isle of Bliss" (Lycksalighetens $\ddot{O})$. This poem was a long but splendid treatment, in dramatic form, of a Celtic fairy-tale; it was not free from satirical references to contemporary conditions in art and society, but it teemed with beautiful lyric passages and contained the philosophical ideas of the movement. But what had the Fosforists as a body really accomplished, and what had been the character of their creative achievements?

In spite of strenuous opposition the Fosforists had returned from the battlefield with a victory for Swedish culture. And it was natural that they should; they had nothing to lose and everything to gain. By their zealous encouragement of German literature and philosophy a wholesome spirit, more akin to the Scandinavian temperament, had been infused. Some members of the Old School, to be sure, had known the German classics before the Romantic School was born; but, barring a few translations, they seem to have kept their knowledge mostly to themselves. The Fosforists, on the other hand, stirred up things by publicly proclaiming the value of the new gospel. Fosforism, like many aspects of Romanticism in Germany, stood for a deeper meaning and spirituality in life and letters; it stood for the irrational, for the eternal and infinite, for the identity of nature and spirit, for the divinity of art and poetry, for mystical longing, for freedom and religiosity. Sweden is indebted to Fosforism for a profound, healthy, quickening impulse to both her literature and her literary criticism, and for inaugurating the serious study of esthetics.

The failings of the Fosforists were numerous and serious, and an impartial critic must often deal, therefore, with theoretical aspirations rather than with actual, positive accomplishments. No original masterpiece was produced within Fosforistic circles until several years after the polemic storm had passed away; that is, not until Fosforism, in its more restricted 
sense, had disappeared. Here and there, indeed, a lyrical gem made its appearance. Hedborn had a gift for the picturesque and wrote some choice hymns, the consumptive Per Elgström was an excellent colorist, and his poems revealed an elegiac, melancholy, or mystic style; but these were not great poets. Neither did Hammarskjöld, the law-giving Friedrich Schlegel of Swedish Romanticism, exhibit any marked creative ability. He was too busy mapping out programs, ridiculing French taste, and attacking Alexandrines to do anything really original, and Palmblad's literary contributions were mostly reviews and translations. Atterbom, the life-long leader and the greatest of the Fosforists, was the most prolific writer, but his poetry was often obscure and his best work, mentioned above, did not appear until he was a middle-aged man. We see, then, that Fosforistic activity was largely polemic and negative in its character; beyond this it was imitative, critical, and metaphysical.

To what extent the Fosforists, and other poets who actively sympathized with them, were influenced by German Romanticism, may best be seen by calling attention to a few additional features of the Swedish movement. The Schlegels, Tieck, Novalis, and the classical German authors are lauded to the skies and quoted as authorities at every opportunity. The atmosphere is full of Stimmungspoesie with constant reference to the invisible or infinite. Oändlighet (Unendlichkeit) is the prevailing keynote in the Romantic poetry of Sweden. As in Germany, much of it was unintelligible, and this is particularly noticeable in the earliest poems of Atterbom, as in some strophes of the Prolog to Fosforos. Moonlight, twilight, darkness, and night appealed also to the Uppsala youngsters, and rich coloring was a common phenomenon. Johan David Valerius ( $\left.1776-185^{2}\right)$ was criticized for moralizing his drinking songs, showing a tendency toward the "Lucinde" system of morality; and here and there we discover a strong poetic sympathy for the Holy Virgin and Catholicism. Spanish and Italian authors were studied and translated, and this led to experimentation in all kinds of Southern verse-forms. The terza-rima and canzone were introduced in the spirit of opposition to Alexandrines, and sonnets were written by the score. 
The November number of Fosforos for I8Io opens with twenty sonnets by Atterbom.

In their hostility to French forms, the Fosforists often went to the other extreme, and they have been severely criticized for being literary slaves of Germany. There proved to be no ultimate danger in this relation, however, for, in the first place, the Fosforists did not succeed in fulfilling all their most radical promises. Then, too, there are differences between the German parent and its Swedish offspring showing a certain independence, and that some of the foreign Romantic seed had fallen by the wayside, so far as absolute imitation was concerned. Original productions among the younger Swedish Romanticists were almost exclusively lyrical, not only in content but also in form. "Wilhelm Meister" was hailed with joy in S'weden as well as in Germany, but it produced no imitation of its genre in Sweden. Sweden had no formless Romanpoesie in the narrow sense of the term; though Swedish poetry teemed with apotheoses of its own art, we find no enthusiast like Ofterdingen and no peripatetic and almost fanatic "knight of the moon" like Franz Sternbald. In some of these respects, it seems to me, Swedish Romanticism became more sober and sensible than that of Germany, though it may have been due to a lack of genius that this type of the novel was not developed. As already observed, Swedish Romanticists were not theoretically opposed to a freer morality, but practically they led as regular lives as other people and had no such domestic troubles as some of their German masters. Elgström died young through no fault of his own, but Atterbom and Hedborn lived long and happy lives in wedlock. None of the Fosforists joined the Catholic Church, though Hammarskjöld and Atterbom were both much impressed by it.

Interest in Scandinavian antiquity formed only one part of the pretentious Fosforistic program and, as this review is intended to show, this was often subjective and allegorical. The Goths, however, confined themselves to this one part and aimed to make it objective, a fresh and living phenomenon in Swedish culture. It will be in order, therefore, to describe briefly the history and characteristics of the Gothic School. 
The Gothic School (Götiska Förbundet) was founded in the beginning of the year I8II. The members of this brotherhood met and adopted a constitution on February I6. "A morally patriotic thought," or spirit, was to be the kernel of the Society, and paragraph 3 of the statutes provided that every Brother should consider himself "absolutely in duty bound to investigate the sagas and chronicles of the old Goths," meaning by the "Goths," the old Norse ancestors; hence the name of the movement. ${ }^{1}$ Its leader was the chancery-clerk Jakob Adlerbeth, trained in love for his fatherland from early youth. Men of any profession, possessing some striking "Gothic" qualification, were eligible to membership, though authors and artists were especially desired. Eventually new members were elected to the number of one hundred. As in the case of the Fosforists, the enthusiasm was greatest at the start; the year I8I I is both the beginning and the culmination of the general interest in the society. Sixteen meetings were held the first year, thirteen the second, but after 1825 no more than five meetings were ever held in any one year. But the activity continued with considerable force for about a dozen years after the founding of the Förbund, and during this time ten volumes of its literary organ, Iduna, appeared. After the formal dissolution of the society in 1844 there appeared an eleventh and last number in $\mathrm{I} 845$.

The "Gothomania," as it was sometimes called at first, was characterized, like Fosforism, by one-sidedness and exaggeration. Scandinavian antiquity was to be resuscitated, not only in art and poetry, but, to a certain extent, in life; not only was Icelandic literature to be studied, but, whenever possible, the viking customs were to be revived. Naturally the Goths took the initiative at their regular meetings. Each Gothic Brother first adopted the name of some heathen forefather, and was supposed, within three months after his election to membership, to give a discourse on his ancestral namesake to the members of the society. This pagan name was used in address, both at the meetings and in private correspondence among the members. Thus Tegnér became Bodvar Bjarke; J. P. Lefrén,

1 See Hjärne: Götiska förbundet, pp. II and 15. 
Guttorm; D. Nordin, Sigfried; P. H. Ling, Bosi ; Adlerbeth, Rolf ; J. H. Wallman, Helge; and Geijer, Einar Tambaskjälver. Tremendous enthusiasm, not to say boisterousness, prevailed at all gatherings, and the character, courage, manliness of the original inhabitants of Sweden were constantly emphasized. The members drank mead, both out of individual horns and out of a common vessel called "Bragebägaren" (the Bragecup) and saluted each other in appropriate heroic terms. Sometimes the meetings were held out of doors; then stones were carried together and placed in a circle to represent a primitive Norse Thing or court. At the reading of poems with national or patriotic themes, or upon hearing the results of investigations in the Swedish past, the Brothers gave unbounded applause. At times they waxed sentimental; it is said that Geijer in reading Tegnér's "Nore" had to stop for tears. ${ }^{1}$

The literary leaders of the Gothic movement were Tegnér, Ling, and Geijer. The first two took an active part in the management of the society, but after a time Ling resigned his membership for reasons which will be discussed later. But in his research work Ling continued to be the very personification of an exaggerated Gothism, and his poems continued to receive applause in Gothic circles. Strangely enough, Ling contributed but one article to Iduna. This was published in $18 \mathrm{I} 4$, and the subject was "Gymnastics." In the interim this periodical had already contained some of the best poems ever composed in the Swedish language. Geijer, the real chief in I8I I, published "The Viking" (Vikingen), "The Last Skald" (Den siste skalden), and "The Last Combatant" (Den siste kämpen), in the first number, and later, at the beginning of the third decade, when fragments of "Frithiof's Saga" appeared, they were published in the Iduna. The fourth great Goth was A. A. Afzelius (1785-I87I), a clergyman and author of the popular "The Reel of the Water-Sprite" (Näckens polska). He eventually translated the Elder Edda but did his best work in Swedish folklore. Together with Geijer he published, in I8I4-I6, a large collection of Swedish folksongs ("Svenska folkvisor") in three volumes.

1 See Hjärne: Götiska förbundet, p. 2 I. 
The Gothic movement in Sweden was merely one way of expressing the spirit of independence and nationality that arose all over Europe, as a protest against rationalism, cosmopolitanism, and Napoleonic oppression. After I806 the Swedes were involved in the continental wars, through their German possessions. Then came the loss of Finland and the Swedish revolution of I809. No wonder, then, that national disasters should help prepare the soil for patriotic utterances of any sort. Now, as Hjärne ${ }^{1}$ rightly contends, the best method to reawaken a national self-consciousness is to revive the memory of what has produced a great people in the past. The Gothic School, therefore, was enthusiastically welcomed, especially by the young, even if some old and prejudiced conservatives looked with fear and suspicion on the re-introduction of a pagan system of mythology. The Goths did a tremendous amount of good by stimulating interest in the Scandinavian saga-age in general, and Swedish antiquity in particular. Every true patriot wanted to know something about the Asa-doctrines, the Eddas, and the life of the viking ancestors. Runes were deciphered and heathen relics collected. Though unsuccessful in his attempt, the consistent, militant manager of the society, Adlerbeth, tried to have a learned Icelander imported to give instruction in Old Norse. Manuscript treasures were opened up and gradually the vehemence of youth gave way to a calm, scientific spirit of investigation. For instance, Afzelius published in the third volume of Iduna, both text and translation of "Voluspá" from the Elder Edda, after they had both been inspected by the Danish philologist Rask. Snorre Sturleson's "Heimskringla" was published by men outside of the society and was probably influenced by it. $^{2}$

We have seen that in the case of the Fosforists the main foreign influence was German; with the Gothic School it was Danish. Anton Blanck, in his excellent dissertation on "The Northern Renaissance" (see bibliography), has shown the increasing popularity of Northern themes in French, English, German, and Danish literature during the eighteenth century.

1 Götiska förbundet, p. 9.

2 Ibid., pp. 38-9. 
Indirectly, all these foreign tendencies converge toward the Gothic movement in Sweden, but directly, and mostly through the literary work of Oehlenschläger during the first decade of the nineteenth century, outside influence came from Denmark. We shall return to this topic in connection with the chapter on art.

In Denmark the new German Romanticism and the national movement were fused in one person, Oehlenschläger, with the balance of power decidedly in favor of the national element. In Sweden these two tendencies, to be sure, were centered in two literary factions, but their propagandists often combined forces, and at times we find, as in Denmark, both Gothic and Fosforistic ideas in the same poet. The Goth, Ling, was a Romanticist in spite of himself; Geijer, after the first patriotic ecstacy had subsided, was more of a Fosforist than a Goth; Afzelius contributed to both Fosforos and Poetisk Kalender, and, in turn, Atterbom and Hammarskjöld contributed to Iduna. Nicander, an active member of the Gothic School, had a genuine Romantic longing for the South, and hostile critics when they attacked one movement generally attacked the other. Often the two worked sympathetically side by side, or they felt at liberty to make friendly encroachments upon each other's territory. Both were prompted by ardent search for "det ursprungliga."

The work of the Swedish Romanticists in the field of Scandinavian antiquity was not one of discovery; it was a revival movement. It was an enthusiastic attempt to crush any spirit of indifference that prevailed toward the culture of the preChristian ages in Scandinavia, and to rekindle a spirit of pride in the past. What the Romanticists sought, was to arouse a more general and permanent popularity in Old Norse themes among their countrymen and to make a more thorough study of the original sources. An interest in Norse mythology and history had existed, however, in various parts of Europe, for nearly a century and a half before the "Goths" took up the subject. To be sure, it was spasmodic, the conceptions now and then were based on misunderstanding, and the conclusions were often speculative in the extreme; but the evidence of a 
Gothic inclination was there, and it will repay us to review briefly this evidence before we proceed to the revival in Sweden during the Romantic period. ${ }^{1}$

During the decade $1750-1760$, when so many Romantic tendencies began to assert themselves in Europe, we begin to detect an interest in Norse antiquity. In fact, northern barbarian literature by virtue of its wildness and power becomes one of the most effective weapons in the struggle against classicism. ${ }^{2}$ Paul-Henri Mallet, a Swiss, gave the impulse for the study of the Scandinavian ${ }^{3}$ past when he published in 1755 his "Introduction a l'histoire de Danemarc." In addition, Mallet made several translations from the Eddas and showed a love for the Old Norse religion. He made the mistake, however, of regarding the Scandinavian as a branch of the Celtic family.

In England, Percy's interest in Old Norse was due to Mallet's book, which was translated by Percy in 1770 . In the meantime Percy had published in London ( 1763 ) "Five Pieces of Runic Poetry," translated from the Icelandic. "The Bard" (I754-I757), by Gray, had likewise a Norse as well as a Celtic element. Gray himself states that he borrowed from the Norse 4 and he made two translations,- " The Fatal Sisters" and "The Descent of Odin." The Ossianic poems teem with viking elements, and Blanck asserts that Macpherson obtained "the apparatus" for his Celtic epic from Gray and Mason. ${ }^{5}$ Frank Sayers (I763-1817) published in 1790 "Dramatic Sketches of Northern Mythology," containing three minor dramatic efforts, all localized on Celtic or Northern territory. ${ }^{6}$ A translation from a Latin version of the poetic Edda by Amos Cottles appeared in Bristol in 1797..$^{7}$ William Herbert,

1 A part of this introduction is based on Anton Blanck's “ Den nordiska renässansen," Uppsala, $19 \mathrm{II}$, and is, in a sense, a review of the most important data of this work. Blanck's investigation covers 433 pages, plus an extensive bibliography. I am much indebted to Blanck for that part of the history which precedes the year 1810. His results and references have, of course, been verified whenevet possible.

2 See Blanck, p. 39.

3 "Scandinavia" throughout this study is to be taken in the old, broad sense, naturally, including Denmark and Iceland.

4 Cf. Blanck, p. 84.

5 Ibid., p. II 2.

6 Ibid., p. I 19.

7 Ibid., pp. I 2 Iff. 
who had mastered the Scandinavian languages and could use the Icelandic sources, was the first Englishman to take advantage of this knowledge, and published in 1804-1806, in his "Miscellaneous Poetry," some selections entitled "Select Icelandic Poetry." According to Lockhart, Scott studied Scandinavian mythology and wrote essays and read papers on the subject as early as 1792 ; but all thus far, with the exception of Herbert, had followed in Gray's footsteps and used only secondary sources.

Fr. David Gräter (see below), in his "Nordische Blumen," refers on page xi to a free English translation of "LodbrockarQvida" by the Reverend James Johnstone, A.M., published in I782. Blanck does not mention Johnstone at all, but from an article in the "Dictionary of National Biography," Vol. XXX, p. 78, by Thompson Cooper, we obtain the following information:

James Johnstone (d. I798), a "Scandinavian antiquary, was a Master of Arts, though of what university is not stated, and a clergyman of the established church. For several years he was chaplain to the English envoy extraordinary in Denmark." $\mathrm{He}$ was afterwards rector in Ireland. From 1780-1786 he published in Copenhagen, London, or Edinburgh, six different works on Scandinavian, Celtic, and Celto-Norman literature and antiquity, consisting both of originals and translations. The translation to which Gräter refers contained also "a literal Latin version, and an Icelando-Latino Glossary and Notes." Johnstone's first work, which appeared in I780 in Copenhagen, bore the title "Anecdotes of Olave the Black, King of Man, and the Hebredian Princes of the Somerled Family. To which are added Eighteen Eulogies on Haco, King of Norway; by Snorre Sturleson, poet to the monarch; now first published in the original Icelandic; from the Flateyan and other Manuscripts; with a literal version and Notes." I have not seen these editions myself.

Independent of any impulse from England there arose a northern renaissance in Germany, where Gottfried Schütze (I719-1784) became an important pioneer mediator between the old school and the new. He was a pupil of Joh. Georg 
Keyssler, the author of "Antiquitates selectae septentrionales et celtae" (I720), was a well-read scholar, and published in German a popular exposition of Norse mythology. Schütze made no distinction between the Celts and the Germans; even the old Norsemen, according to him, had both druids and bards, and this mistake was no doubt responsible for much of the later confusion in this field. Schütze's real importance was as teacher of Gerstenberg, whose "Gedicht eines Skalden" (I766) marks the beginning of a new literary genre in Germany. Blanck devotes several pages to a discussion of Gerstenberg's work.

German interest in the North is closely connected with the worship of Ossian, and this is well illustrated in Gerstenberg's pupil, Klopstock. His "Hermannschlacht" ( 1769 ) is a mixture of the antique, Ossian, and the North. But Klopstock had no sense for the historic or the characteristic and his Norse divinities are, for the most part, mere names. ${ }^{1}$ Michael Denis translated some Icelandic poems, such as "Voluspá" and "Vegtamskvida." The so-called "Bards," such as Karl Friedrich Kretschmann, ${ }^{2}$ and the "Gottinger Hain" worked along the same lines as Klopstock, but with both groups of poets the Ossianic element predominates. This is likewise the case with Herder $^{3}$ who, in "Von deutscher Art und Kunst" (I773), published "Über Ossian und die Lieder alter Völker." But in Herder's famous cosmopolitan collection of folksongs, "Stimmen der Völker," as it was called in the second edition of 1785 , we find some of distinctly Norse origin, and indeed some from Greenland. It was Herder who in Strassburg called Goethe's attention to the Eddaic poems and gave him a copy of Resenius's Edda. ${ }^{4}$ Herder distinguished himself from his predecessors by using more scientific material and adopting an historical

1 Cf. ibid., p. 158 .

2 Ibid., pp. $x 6$ Iff.

3 For Herder see ibid., pp. 164-179.

4 See " Dichtung und Wahrheit," Weimar edition, Vol. 28, p. 143. In the same passage we learn that Goethe was much interested in saga material, and that he was already acquainted with Mallet. The Edda mentioned was an edition by the Dane Per Resenius (1625-88) of Copenhagen. It contained the original of the Snorre Edda together with a Latin and Danish translation by two other scholars. Resenius published in 1683 a Lexicon islandicum by the Icelander Gudmundus Andreae (d. 1654). Cf. article on Resenius by Weiss in Bibliographie Universelle, Nouvelle edition, Vol. 35. 
method of study. He exhibited much independence of thought even if, as Blanck believes, ${ }^{1}$ Mallet was his main reliance.

Herder's originality of thought becomes of special interest when we compare his views on Norse mythology with those of the cautious and classic Scandinavian critics at the beginning of the Romantic period. In "Iduna oder der Apfel der Verjüngung," published in 1796 in Die Horen, Herder states the objections to the coarse and grotesque in the new mythology, but sees several motives worthy of artistic treatment. The Northern characteristics, he finds, are deeds and strength of soul. But the Norse gods should not have greater prominence than other poetic systems. Greek mythology was not to lose its incontestable rank, but Herder pleads for a recognition of the Norse system proportional to its importance. The raw and barbarian element must be sacrificed. This same idea is embodied in "Zutritt der nordischen Mythologie zur neueren Dichtkunst" (Adrastea $\mathrm{X} \mathrm{I} 8 \mathrm{0} 3$ ). It will be essential to remember Herder's views when we discuss the new mythology and art.

Friedrich David Gräter (I768-I830) ${ }^{2}$ was something more than a dilettant in Norse subjects and did some work of real scientific importance. He acquired a good philological training; he studied Danish and Old Norse and his "Nordische Blumen" of 1789 contained translations from the 1787 edition of the Edda published by the Arne-Magnussen Foundation. Although the character of the original is rather sparsely preserved the translations show very conscientious work. In I79I-I8I2 appeared his organ Bragur, Ein literarisches Magazin der deutschen und nordischen Vorzeit, in eight numbers, but it contained little of value for the North. This was followed by Idunna und Hermode (1812-16), which contained, as did Bragur, reviews, translations, and minor articles. ${ }^{3}$ Kose-

1 Blanck, p. 176.

2 Ibid., pp. 179 ff.

3 According to Herder, Gräter's "Northern Flowers" were received with an "almost unreasonable" frigidity. Cf. "Zutritt der nordischen Mythologie zur neueren Dichtkunst" in "Sämmtliche Werke" (Suphan edition), Vol. 24, pp. 312-313. In a footnote on page 312 , Herder refers, among others, to a Karl von Münchhausen, who had distinguished himself in the new mythology. 
garten (I758-1818), in his “Gedichte" (I788), published a part of Ragnar Lodbrok's death-song, and Fouqués “ Sigurd der Schlangentödter," the first part of a trilogy "Der Held des Nordens," appeared in 1808 . In the meantime the Edda-translation of the brothers Grimm was being advertised and the period of German dilettantism in Norse mythology was over. ${ }^{1}$

The North does not play a very large rôle in French literature of the eighteenth century. In fact, up to 1800 , when Madame de Stael's "De la littérature" appeared, the "cold and distant north" remained in a hazy gloom and the interest in it was merely one of curiosity. ${ }^{2}$ Nevertheless, the influence of Mallet's work is noticeable in France also. In the didactic novel "L'Arcadie" by Bernardin de Saint-Pierre, Norse mythology is introduced, but the work was of little consequence. Comte de Tressan, in I782, published an Icelandic novel: "Histoire de Rigda et de Regner Lodbrog, Roi de Danemarc," being the fourth part of "Corps d'extraits de romans de chevallerie." Madame de Stael was really the first to give the French an idea of the Norse spirit, and her main authority was Mallet. But she believed religiously in the genuineness of Ossian and held that Ossianic and Icelandic literature greatly resembled each other. Hence there came about a nebulousness of conception similar to, if not worse than, the initial conception in Germany. Among the dii minores that followed in this field "Norse" and "Ossianic" must have been taken often as synonymous terms. ${ }^{3}$ It may seem strange that the impulse to revivify the Old

1 In the Harvard University library there is a volume on the Edda with the following title: "Abhandlung abgefasst in einem Schreiben an einen Gelehrten von der alten Isländischen Edda." It was published in Halle and Leipzig, and the date, written in lead pencil, is 1774 . The name of the author, likewise written with lead pencil, is given as Jakob Schimmelmann. I have been unable to find any reference to such a student of Icelandic literature. Blanck does not mention him. The work deals with questions of the genuineness of the Eddas and manuscripts in Uppsala and Copenhagen. It also raises the query whether the German edition promised from Stettin may be expected soon. It is of special interest, since it contains sketches of Thor, Odin, and Frigga.

2 Cf. Blanck, p. 185.

3 In addition to Blanck, the subject of the North in French literature has been investigated by Gunnar Castrén in "Norden i den franska litteraturen," Hälsingfors, 1910. 
Norse element in Denmark should have come from a foreigner; but such seems to have been the case, for it was the sojourn of Klopstock in Copenhagen that became the immediate incentive for the Norse poetry of Johannes Ewald (1743I78I). In a way, as Blanck points out, ${ }^{1}$ this was but a loan, for the Dane, O. F. Müller, had previously furnished the hint for Gerstenberg's "Gedicht eines Skalden" and Klopstock was a pupil of Gerstenberg. But the fact remains that the effective influence at the time came from Germany, and "Rolf Krage" (I769) by Ewald exhibits unmistakable similarities to Klopstock's productions. The Celtic influence is very marked; Ossian plays a large sentimental rôle and the whole is unhistorical. Whereas Oehlenschläger three decades later used Danish, Norwegian, and Icelandic subjects, Ewald limits himself to Danish, using Saxo as his main source. His knowledge of Norse antiquity was very superficial; he confused myth and saga and like his model made no clear differentiation between the Celtic and the Norse. The same nebulous northern tone reigns in "Balder's Death" (Balder's D $\phi \mathrm{d}$ ), r773. Blanck has also detected an influence of Shakespeare on Ewald.

After the death of Ewald, Denmark produced no great poet until we come to Oehlenschläger. Between these two was a reactionary, classical period of didacticism and satire, and during the decade beginning 1780 the rationalistic tendency, under the leadership of the Norwegian Society, ${ }^{2}$ gained the ascendancy. Some interest in Norse literature still prevailed, however, though the method of treatment as well as the general attitude toward the saga had become different. P. F. Suhm (I728-r798), a contemporary of Ewald, and famous for his exhaustive work in the early history of Denmark, ${ }^{3}$ created the novelette with northern theme, but his style is entirely unromantic with hardly any trace of Ossian. ${ }^{4}$ Pram, inspired by

1 Cf. Blanck, pp. 136ff, and p. 200.

2 So called because its chief, Johan Herman Wessel (b. 1742), was a Norwegian.

3 His history of Denmark contains fourteen volumes, though it extends only to the year 1400 .

4 Ibid., p. 220. With respect to Suhm's work, Dr. Horn says: "The most remarkable are his Norse tales, which made a certain sensation, not only because they were new, but also on account of their sentimental style, 
Wieland, published (I785) "Staerkodder, et digt i femten sange," which was the most important creation in the Norse field during the rationalistic period. ${ }^{1}$ Even satire pounced upon northern subjects and Jens Baggesen's famous "The Origin of Poetry" (Poesiens oprindelse) is a mythological parody based on Wieland's “ Komische Erzählungen.” Blanck points out that Baggesen's picture of Gunlöde influenced all successors, and especially Ling in Sweden. ${ }^{2}$ O. J. Sams $\varnothing \mathrm{e}$ (I759-1796) wrote three novelettes with Norse themes, of which the first, "Frithiof," written in the decade beginning I780, was based on the Icelandic Frithiof-saga.

It will be remembered that the Danes did much work during the last quarter of the century in Old Scandinavian history and philology. And this is but natural; Icelanders had to come to Copenhagen to study, a fact which in itself was an incentive to keep up ancient traditions. Manuscripts were deciphered with great zeal and profit, and the Arne-Magnussen Foundation furnished financial support. The latter published its renowned editio princeps of the Edda in I787, Shфning's edition of the "Heimskringla" had appeared in I777, Rasmus Nyerup's "Review of the most Ancient Poetry and Literature of the North" (Udsigt over nordens aeldste poesi og des litteratur), I79I, the "Snorre Edda," by Nyerup and Rask, I808, not to mention the influential literary work of Oehlenschläger, which begins along with the new century. We shall have occasion to return to Oehlenschläger later.

Swedish interest in the saga element can be traced back to the seventeenth century; a century which, in many respects, was the golden age of Sweden. During the beginning of the Stjernhjelm period (I640-I740), Stjernhjelm (I598-I672) himself had attempted Icelandic as a basis for a prose style but was not very successful. ${ }^{3}$ The significant fact, however, was which was anything but genuine Norse, but they happened to satisfy the taste of that period." ("History of the Literature of the Scandinavian North," p. 203.)

1 Ibid., p. 223.

2 Ibid., p. 230.

3 Cf. Schück: in Introduction to "Svensk national-litteratur" (Sv. N. L.), Vol. VI, p. 5 . 
the actual discovery of the Icelandic literature about this time, and as common property of the North it was called "Gothic" (Götisk). Schück writes :

"A multitude of Icelandic sagas, mostly from the period of decline in Icelandic literature, were then translated into Swedish, although only a small number were printed, and one needs only to read the catalogs of several of the libraries of the nobility to find how immensely popular these Icelandic sagas were at the close of the seventeenth century and at the beginning of the eighteenth." 1

In fact, S'chück goes so far as to say that inasmuch as most of the novel literature during this period circulated in manuscript form, and time for making copies was inexpensive in the country, one might claim without exaggeration that the Icelandic saga was the novel of the Swedish Carolingian age. ${ }^{2}$ But the popularity of the saga, at least among investigators, was pseudohistorical rather than literary or critical, and the "Golden Age" produced no literary expression of its sympathies for the Norse element. We may assert that, both among ordinary readers and among the more educated classes, this sympathy was prompted by an indefinite and patriotic feeling of curiosity for an unknown, fabulous antiquity. This feeling, as is well known, had been aroused during the last quarter of the seventeenth century by a group of men, antiquarian in their intentions, and of whom the most important was the fantastic polyhistor Olof Rudbeck the Elder (I630-1702), in whose Atlantica $(1675-1702)^{3}$ fabulous historiography was carried to its climax. The spirit of Rudbeckianism that followed reigned up to about $1760,{ }^{4}$ i. e., for almost a century. This spirit of "Rudbeckianism," or unbounded patriotism and faith in Sweden as the cradle of all civilization, must be understood if we are to comprehend a second form of it during the Swedish Romantic period. The foremost Romanticist, Atterbom, a "Fosforist" and not a formal "Goth," had great admiration

1 H. Schück: "Den götiska skolan” in "Ur gamla papper." Sjette serien, p. 218.

2 Ibid., p. 218.

'3 Rudbeck's specialty was medicine and at twenty-two he discovered the system of lymphatic vessels. Bartholin, a Danish scholar, claimed the same honor at about the same time.

4 Blanck, p. 316. 
for Rudbeck's efforts and devotes 244 pages of his "Biographies and Lectures" ${ }_{1}$ to an appreciation of Rudbeck's unscientific but fascinating investigations. ${ }^{2}$

But there was a well-marked Norse tendency before Rudbeck. A royal decree of November 23, 1666, provided for the preservation of antiquities, including saga material and viking songs ("Kämpa-och historie-visor,"). ${ }^{3}$ Among the pioneers in this line was Verelius (I6I8-1682), who published the

1 P. D. A. Atterbom: “Minnesteckingar och tal.” Förra bandet: “ Minne af Olof Rudbeck den äldre.” Örebro, 1869.

2 For the benefit of readers who may not be acquainted with Rudbeck's "Atlantica," a brief word of elucidation, based on Atterbom's characterization, may be in order. First, as to the name. While engaged in historical investigation Rudbeck discovered a similarity in names between those in Plato's mythical "Atlantis," the seat of his ideal republic, and those of certain localities in Sweden (cf. Horn, History of the Literature of the Scand. North, p. 340). Immediately Rudbeck conceived the idea that Paradise had been located in Sweden and (undoubtedly influenced by an earlier Johannes Magnus, who tried to make similar deductions) that Noah's grandson Magog had founded the Magogian, i. e., Gothic kingdom in Sweden and from there the whole world had been populated. In other words, all culture came from Sweden and was then transmitted to the Greeks by the Phenicians. The whole work teemed with ingenious etymologies and there is said to be a remarkable coincidence in names between Rudbeck's sources and the Norse terms. Rudbeck tries to identify classic and Norse myths by the linguistic method. He even attempts to connect the Swedish word "Necken" (a musical, male water-sprite) with "Noach" (Noah), both being lords of the water. But even if his imaginations ran wild at times, Rudbeck's effort was a most serious one, and his work shows some desultory knowledge about the Edda, Norse mythology and history, and about Icelandic scholars, such as Sämund Frode and Brynjolf Svenson. The work was too gigantic and was never finished; it appeared in four immense parts, of which the last is a fragment. Part I alone had $89 \mathrm{r}$ pages with tables and drawings. As it was, the enthusiastic author was unable to carry his history farther than to Abraham. Rudbeck's "Atlantica," naturally, created a tremendous excitement all over Europe. Many believed in it, others doubted, and again others regarded it as colossal foolishness, while the more credulous and superpatriotic Swedes felt proud and delighted. But indirectly, the "Atlantica" had an historical value, for it prompted further research, and Atterbom (Lefnadsteckningar och tal. Förra bandet, p. $7 I$ ) gives Rudbeck credit for inaugurating a new epoch in the investigation of antiquity. Through the suggestion of Rudbeck many Icelandic sagas were printed between 1673I 700, some at his own expense (ibid., p. I7I). For the details of this interesting work I refer to Atterbom's review. I believe Atterbom to have many qualities in common with Rudbeck; a matter which we shall take up in the first chapter.

3 Cf. Atterbom: Minnesteckningar och tal., pp. $83 \mathrm{ff}$. 
"Hervarar Saga" in 1672, and it was from him that Rudbeck received the impulse for his work. Atterbom believed Verelius to be "a most thorough interpreter of the runes and the newly discovered Icelandic literature." ${ }^{1}$ Johan Perinskjöld (1654-I720) published the editio princeps of Snorre's "Heimskringla," and Johan Hadorph collected rune-stone material. Rudbeck's attempt to prove that classic mythology was nothing but a distorted Swedish system served to heighten the national feeling, even if the fundamental facts in the attempt were spurious. As a consequence, a super-heated patriotism lived on, and with it an interest in Norse literature. J. H. Mörk (I7I4-I763), a Rudbeckian, and Sweden's first novelist, wrote, in I742-1745, "Adalrik and Göthilda," an original novel with an heroic national motive from Northern antiquity. Björner's "Tales of Combat" (Kämpadater) had appeared in I737, and Göranson published Snorre's Edda in 1746 and Voluspá in 1750. As Schück points out, Mörk's novel, Verelius's "Hervarar Saga," and Björner's "Tales of Combat" were read with pleasure in the country districts as late as the beginning of the nineteenth century, and both Tegnér and Atterbom got their first impressions from them. "Here was a channel, then, which connected Rudbeck's time with that of Geijer."2 After I750 the rise of a critical school, led by such men as Dalin, was rapidly putting an end to speculation and a decade later Rudbeckianism had practically disappeared.

Now, for a number of years, there was no fruitful experimentation with saga elements. Then comes Olof Rudbeck, (I750-I777), the great-grandson of Rudbeck the Elder, who, "during his last days," devoted himself to "the zealous study of Old Norse literature." 3 Uno von Troil, Archbishop of Uppsala (d. 1803), had won a reputation in a series of letters (Uppsala, I777) about Iceland which were later translated

1 Ibid., p. 89.

2 "Den götiska skolan," pp. 218-19. On page 219, also, Schück recalls the movement in Germany that was parallel to Rudbeckianism in Sweden, namely, the fanatic Schwärmerei for German antiquity aroused by Tacitus's "Germania." Then Lohenstein, the Edda and Ossian, all served to intensify this enthusiasm and, finally, all were united in the poetry of Klopstock.

3 L. Hammarskjöld: Svenska vitterheten, 2d edition, p. 292. 
into both German and French. ${ }^{1}$ Finally, a temporary impulse for a resuscitation of "Gothic" material came directly after I777, when Ossian was translated into Swedish. The influence of Ossian ${ }^{2}$ and Rousseau were to be prominent characteristics of the Gothic tendency thereafter.

G. G. Adlerbeth (I75I-I8i8), the father of the leader of the Gothic School, translated Eyvindr Skaldaspiller's "Hakonarmál" in I783, which was printed in Stockholms-Posten in 1790. Adlerbeth detects an intimate relationship between the Ossianic and the Icelandic songs of combat, and in the northern literature he sees the "strong and bold natural features" of primitive man. ${ }^{3}$ The first serious effort to employ Norse myths in modern Swedish poetry was in Clewberg-Edelcrantz's "Ode to the Swedish people" (Ode till svenska folket; Stockholm, 1786). Clewberg was influenced by Gray, ${ }^{4}$ but it is not known with certainty what his sources were. $\mathrm{He}$ was but poorly acquainted with Norse mythology, for he confuses Odin and Thor. ${ }^{5}$ Johan Gabriel Oxenstjerna (I750-1818), in his "The Harvests" (Skördarne), ${ }^{6}$ glorifies, in true Rousseau style, the "Scythians" (Skyterna) as the first inhabitants of Sweden and as founders of Swedish agriculture. Both Oxenstjerna and Adlerbeth tried to depict the prototype of the Swedish farmer. The imagination of Thomas Thorild (I759-1808), a disciple of Ossian, must have been influenced by Rudbeck's "patriarchal conception of the farmers." To this glorification of the primitive agriculturist the Swedish poets were incited by the Norwegian Society, ${ }^{8}$ which had introduced the farmertype into Norwegian popular poetry. And with less difficulty than in Sweden: for the free Norwegian tiller of the soil en-

1 Cf. Hermes, Leipzig, I823, Nr. XVII, p. 242 (Kritisch-historische Uebersicht des Zustandes der schwedischen Literatur seit dem Anfange dieses Jahrhunderts, by Hammarskjöld.)

2 Cf. Blanck, p. 316.

3 Ibid., p. 319.

4 Ibid., p. 329.

5 Ibid., p. 33 I.

6 For an outline of the history of this Alexandrine poem, see Blanck, p. 34Iff. The first version was written in Vienna in $1772-3$, though not printed until 1796.

7 Ibid., p. 4 10.

8 Cf. above, note 2, p. 17 . 
joyed a greater prestige, comparatively; he came nearer the embodiment of the Rousseau ideal, and the exaltation of him gained favor more rapidly than in a country governed by the nobility. ${ }^{1}$ The Rousseau spirit is very striking in an important and interesting article entitled "The Golden Age of Sweden during the Reign of the Lodbrok Dynasty in the Tenth, Eleventh, and Twelfth Centuries," which appeared in Vol. 4 of "Publications of the Society for the Popularization of General Knowledge" (I794-I798). ${ }^{2}$ Here three pagan centuries are represented as an enviable, paradisian age, with the detrimental results of civilization lacking. ${ }^{3}$ There was no poverty, no class distinction, not too many officials, and all the rudiments of a true religion, though heathen, were present. The fact that such a laudatory exposition of the viking period received considerable attention is not surprising. ${ }^{4}$

Even the correct Gustavians employed the Norse saga element in a superficial way. The king himself did not meddle seriously with Norse themes, but representations of Swedish antiquity were to be included in the national repertoire of the theater. But all such representations proved utterly devoid of historical truth or local color, and the King's " erotic bagatel" "Frigga" (I783) is nothing but the imitation of a classic where the name of Jupiter has been changed to Odin. ${ }^{5}$ Several dramatists of the king's coterie adopted Norse themes, but with the same result. ${ }^{6}$ The most important one of these was Gustaf af Leopold's tragedy "Oden," which made its début at the Royal Theater in I790. There is nothing historical in it except the pretended journey of the Asa-tribe from the Black Sea to Scandinavia, at the time of Pompey. The scene

$1 \mathrm{Cf}$. ibid., pp. 416 and $418 \mathrm{ff}$.

2 Swedish name of periodical : Skrifter af sällskapet for allmänne medborgerlige kunskaper," and that of the article: "Sveriges lyckliga tidhvarf under Lodbrokiske konungaättens regering uti 9:de, ro:de, och I I : te århundraden."

3 Cf. G. Ljunggren : Svenska vitterhetens häfder, Del III, pp. 394-5.

4 Blanck states very significantly that the Gothic School in Sweden was the most complete expression "of this national Rousseauism," p. 428 .

5 Blanck, p. 35 I.

6 Ibid., p. 355 .

7 Cf. Appendix : Notes on Leopold. 
is laid in Asia and Pompey himself is introduced into the drama. "Oden" was written according to the French style in Alexandrines, and so, in spite of its name, it gained but little sympathy from the Romanticists. The last of the Gustavian efforts in this line was Adlerbeth's "Ingiall Illråda" (I799); and it was not much of an improvement over its literary patterns in the same genre, but it did have a tendency toward local color.

For the sake of a certain completeness there remains to be mentioned, in this connection, a few names of miscellaneous character. Thorild, to whom we referred a moment ago, should be remembered as a precursor of the "Goths" through his work on local folksongs (I805-I806). ${ }^{1}$ Hammarskjöld mentions a Matthias Bjugg, who was "nourished by love for Norse antiquity." 2 At the close of the century A. E. Afzelius urged the use of Norse mythology in modern poetry, and ventured to compare the classic myths and the new. ${ }^{3}$ He praised Dalin, Fru Nordenflycht, Gyllenborg, ${ }^{4}$ and Leopold for experiments along this line. Peter Tham and Magnus Adlerstam were two dilettants in the investigation of the saga. The former was really a pupil of the remote Rudbeck with no definite remarkable work to his credit, but a man who acquired a name by his originality and enthusiasm for Swedish antiquity. Tham was finally elected to membership in the Gothic Förbund. $^{5}$ Jakob Fredrik Neikter, in I785 librarian and professor of literature at the University of Uppsala, published in I793-I799 a very romantic-sounding Latin treatise, "De gente antiqua Troll," in six parts, showing a scientific interest in the primitive man himself. The "Trolls" were supposed to be the oldest inhabitants of Scandinavia, who had been forced to recede to the innermost parts of the forests by the

1 "Götamannasånger eller dalvisor." They were published in Geijer's edition of folksongs, 1819. See p. 404 and note 2 on same page.

2 Svenska vitterheten, 2 d ed., p. 420.

3 Cf. Blanck, pp. 298 ff.

4 The Norsism of these three had no more intrinsic value than that of Leopold.

5 Tham had a quarrel later with Ling about the location of the ash-tree Yggdrasil, the Tree of Time in Norse mythology, whose branches extend over the whole world. Tham claimed it was located near Dagsnäs, Tham's home. The quarrel was symbolic of the time. 
coming of the Asas. ${ }^{1}$ Neikter also published a number of geographico-historical treatises (179I-1800), all in Latin, about the early history of Scandinavia and Iceland in general, and about Sweden in particular. Blanck thinks it possible that Geijer learned some of his Icelandic from Neikter. ${ }^{2}$ Nils Henrik Sjöborg, professor of history at the University of Lund, did much for the study of Icelandic in the southern part of Sweden. His "Introduction to a Knowledge of the Antiquities of the Fatherland,"3 a valuable book for its time, appeared in 1797 , and his Icelandic grammar in $1804-1806 .{ }^{4}$

It might appear at first from the above compilation that an actual "revival" of the saga element was unecessary. But at close range it becomes evident that much of the activity thus far had lacked the essentials of permanency. Something had been done in Old Norse philology and history, but much of it was superficial and unscientific, and examples of original "Gothic" poetry with any positive value were extremely rare. 'After all, the number of connoisseurs and champions of the indigenous, legendary material was small, and, unlike other subjects, the cult of the saga had not attained a place in literature, or among the Swedish people, commensurable with its value. Sjöborg had tried to keep up Norse traditions at Lund, and Neikter at Uppsala, and both must have had some influence on their younger contemporaries, but Blanck declares (in speaking of the condition at Uppsala) that the "knowledge of Icelandic during the first decade of the nineteenth century had almost died out." What had been accomplished before I8Io in Sweden, then, could, at the most, serve only as an introduction for the more intensive and general work of the next generation. It was left for the Romanticists to introduce the local color, life, vitality, and spirit that would give the saga element an undisputed place in Swedish literature.

1 Blanck, pp. 252-3.

2 Ibid., p. 297.

3 "Inledning till kännedom af fäderneslandets antiquiteter."

4 "Grammaticae islandicae electa." Other publications of Sjöborg were : “Rigsmal” (1801) ; “Lodbrokar-Qvida” (1802), translated and edited with glosses; "Gautamal lingua antiqua scandinaviae" (I8II).

5 Blanck, p. 297. 


\section{CHAPTER I}

\section{The Interest of the Fosforists in Scandinavian Antiquity}

Vår nya skola egde emellertid i sig sjelf ett så starkt nationelt element, att den vid sidan af den romantiska dikten förstod att uppsöka det fält, som för den skandinaviska norden eger en så stor betydelse och för densamma är särskildt utmärkande, nämligen det fornnordiska lifvets verk och anda. Äfven deruti hade den nya skolan ett stort utmärkande drag och, ehuru bestridd dess förtjenst i detta fall är, våga vi dock påstå, att man äfven mycket från det hållet får taga den $\mathrm{i}$ betraktande. Börje Norling: "Nya skolan bedömd i literaturhistorien."

The so-called Fosforists have never been given full credit for what they accomplished in anything, and certainly not for what they did in familiarizing their countrymen with Scandinavian antiquity. Since their interest in Norse antiquity, folklore and early Scandinavian literature was only one number on their program, it has been an easy matter for hostile and uninformed critics to cover up this tendency with a savage invective against their hobbies and faults, such as German philosophy, Catholicism, and obscurantism. That any good could come from a Fosforist is a matter of skepticism even to-day in Scandinavia, and in the past literary critics have usually assumed that no beneficial impulses or influences of any kind could ever emanate from such a source. Especially is this true with respect to the Fosforists' interest in "Gothic" material, which has been either ignored, treated superficially, or misrepresented. This is illustrated in Malmström's "Grunddragen af svenska vitterhetens historia" (IV and V), and in the bitter antiFosforist Fryxell's "Bidrag till Sveriges litteraturhistoria." The former $(\mathrm{V}, 24)$ gives all the credit to the influence of the Gothic School upon Fosforists. "To be sure," says Malmström, "we can discover certain sympathies in the writings of 
the [New] School for our northern song and saga before [the existence of the Gothic Society] but only scattered traces." But he did not stop to characterize these traces and took for granted that they were of no consequence. Fryxell goes even further and answers "Atterbom's legitimate claim to some honor for his work in folklore" with ridicule ${ }^{1}$ and a charge of unimportance.

Literary historians, also, have imagined an impassable chasm between the Fosforists and the Goths; that their doctrines were irreconcilable, that activity in one of these circles excluded, for the most part, any activity in the other, and that anything of value was accomplished by the Goths only. We know this to be false; if anything, the converse is true. With respect to an interest in national treasures, the Fosforists and Goths were twin brothers, with the birthright in favor of the Fosforist. Against the prevalent misconception in the matter there came a vigorous protest in 1880 from Börje Norling, whose views are summed up in the quotation at the head of this chapter. In the last part of the second chapter of "The New School" (Nya skolan), Norling calls attention to the customary exaggeration of differences between the two new tendencies, and points out how these tendencies often dovetailed into one another, and how their standard-bearers contributed gladly to each others' periodicals. Unfortunately, however, Norling devotes only about nine pages to this large topic and his commendable crticism could serve only as an indicator and not as a permanent demonstration of the misconception. A more recent protest against the same injustice has been filed by Henrik Schück in his brief and popular article on "The Gothic School" (Den götiska skolan). ${ }^{2}$ Schück goes a step further than Norling: he cannot deny the existence of a formally organized Förbund, but questions radically the existence of a Gothic School in any real literary sense. Tegnér, Geijer, and

1 "Bidrag," p. 78. Atterbom had rather incautiously called himself the savior of "The Harp of the North" (Nordmansharpan). This was the name of a collection of folksongs published in 1816 in Poetisk Kalender by Atterbom.

2 Ur gamla papper. Stockholm, 1904, pp. 208-220. It will be observed that this article, like that of Norling, is very brief. 
Ling do not count in his estimation; they were too great, too independent, and too different from each other to assume joint leadership of any one faction. There were some minor literary men, technically enrolled as "Goths," but "from a literary viewpoint the (Gothic) Förbund was of no importance, and the majority of the members were illiterate." ${ }^{2}$ This is a severe charge which certainly cannot be made against the majority of the Fosforists, who could follow a discussion on "Gothic" topics with some intelligence. And so, Schück goes on to say, "The New Romanticists (meaning primarily the Fosforists) were not opposed at all to the idea of revivifying the Old Norse poetry and saw in Iduna, the organ of the Goths, only a companion in arms." 3 It is unhistorical to imagine an antagonism between "New-Romanticism" and enthusiasm for Scandinavian antiquity; the former includes, and is, in a sense, the parent of the latter.

Norling and Schück, we see, have anticipated the justice which must came sooner or later to the ill-reputed Fosforists. What was the extent and nature, then, of the Fosforists' interest in the Old Norse element? First about the leader Atterbom.

From his earliest infancy, saga literature was a favorite reading of Atterbom. "At the early age of six years the boy lay before the fireside with Sturleson, the Vilkina Saga, or Pufendorf's Universalgeschichte beside him."' But what here concerns us most is Atterbom's national tendency as a militant Romanticist as it appears in the literary publications of the new movement. Now, in the very first number of Fosforos, there is undeniable evidence of this tendency. In Atterbom's review of Elgström's ${ }^{5}$ pamphlet, "A Great, Patriotic Way of Thinking” (Om ett stort, ett patriotiskt tänkesätt), which is as much an "esthetic program for the New School as a review of Elgström's pamphlet," 6 we find a Rousseau-like apotheosis

1 Cf. Chap. V of this review, about Nicander and Beskow.

2 "Den götiska skolan," p. 2 12.

3 Ibid., p. 21 3.

4 Johan Erik Thomander: "Inträdes-Tal (öfver Atterbom) i svenska akademien." Svenska akademiens handlingar ifrån år 1796. No. 29, p. 179.

5 This minor Fosforist did not live long enough to accomplish much. Cf. Appendix, note on Elgström.

6 Cf. Gudmund Frunck: "Bidrag till kännedom om nya skolans förberedelser och första utveckling," p. 7 I. 
of early Swedish literature. It is written in characteristic Atterbomian language-notice the epithet "the nectar of genius"-and bears the stamp of conviction and enthusiasm. He writes:

"We are reminded, namely, of an age when Sweden was still the kingdom of the Swedes (Sviars) and, if no more, we wish at least to revive its old memories. We know that Sweden at that time possessed a literature, not for fun, or as a plaything for fullgrown children, not as an agglomeration of contending masses, produced by opportunity and generated by intellectual need; but a real serious literature, fostered by the nectar of genius and preserved by the victories of thorough investigation, an organic example of the ennobling of a powerful nation. ... Philology flourished, and ancient monuments of our forefathers were brought to light with a religious zeal which the modern fashionable smallmindedness has tried in vain to ridicule."1

This tone is, obviously, not one of hostility toward primitive Sweden. On the contrary, it leads us to expect encouragement from the pioneer investigator of S'wedish antiquity.

To Atterbom this meant more often Scandinavian antiquity, for he believed the Edda to be just as much a parent of Swedish literature as of any other Scandinavian poetry. According to Atterbom, the history of Swedish literature does not begin in the middle of the fourteenth century, but with the Eddas, and thorough understanding of the spirit of the Eddas is indispensable to an understanding of early Swedish literature. ${ }^{2}$ Atterbom's interest in strictly indigenous material, then, goes hand in hand with his interest in the Scandinavian saga-age and its literary monuments, and was prompted also, no doubt, by the Romantic search for "det ursprungliga." In his significant comments on Oehlenschläger's works in the November number of Fosforos, I8Io, the tone is even more explicit. A national Swedish poetry, based on Scandinavian mythology, is advocated:

1 "Fosforos" for I 810 , pp. 4 Iff. This quotation is crystal-clear as compared with some of Atterbom's early prose, but even here we can detect a tendency toward a bombastic, hazy phraseology. Of course, an allowance must be made for translation.

2 Cf. "Inledning till svenska siare och skalder," Chap. 2, "Samlade skrifter i obunden stil." Fjerde Delen. Örebro, I864, p. 58. Hammarskjöld differed with Atterbom on these points. 
"We fail to see where it is criminal to restore our fathers" majestic mythology as poetic symbolism. If one should ever consider seriously an individual Scandinavian art of poetry, this would be the only course to take. Whatever this mythology lacks in plasticity, able geniuses, turning their sole attention to these matters, will complete and beautify gradually. Could not those readers who are not acquainted with the demi-sagas of the Edda, be instructed by good manuals dealing with essential phases, and does not sacred popular belief (folktron), at least in certain remote places in the last retreats of Norse Naturpoesie, still cling to several such myths? Does not Thor, that monarch of the lightning, still ride and destroy trolls with his bolts? Do not those mounds blaze in the night, where the giants, whose habitations are shown, sleep beneath their swords? Do not the artful dwarfs laugh within their rocks, and do not monstrous forms converse on moonlit winter-nights around ancestral death-cliffs (ättestupor)? And during the beautiful summer evenings, when the evil-minded fairies of the woods do not venture out of their gloomy dwellings, do not the very elves, those little spirits of light, dressed in a silvery web, still dance beneath leafy trees to the ringing notes of the water-sprite, from out of the aspen-grove on the bank of the river? Those Swedish readers in whom such and other sagas do not re-echo from childhood up are unworthy and incapable of enjoying any kind of poetry. ${ }^{1}$

This strong plea for the Old Northern saga, myth, and superstition is followed by a favorable recension of Ling's "Gylfe," a short allegorical poem in Old Norse dress, on the loss of Finland, which had just appeared in Hammarskjöld's $L y$ ceum. $^{2}$ Here we have a national poem (by an author who later turned out to be the most red-hot radical of the Goths) published in an organ of a Fosforist, Hammarskjöld, and reviewed conjointly by two more, Palmblad and Atterbom, in the organ of the new movement. He hails Ling as the "northern bard," and proceeds enthusiastically as follows:

"That which charms us so irresistibly in this allegory on the fates and hopes of Sweden is something higher than the effeminate and butterfly-like fancy of the ordinary artist. It is Swedish patriotism (nationlighet), or in different words, love of fatherland,

1 Fosforos for 1810, pp. 313-14.

2 For a review see ibid., pp. 376-7. Cf. Chap. III, p. 103 and note 5. 
ardor for freedom, ambition and heroic power. The Scandinavian saga-dress offers willingly its gloomy and colossal splendor to each and every soul who, in rescuing what is most sacred of its character from a tuneless contemporary age, gladly continues to use it [in literary treatments] of his better forefathers, in order to enjoy it among memories and graves." ...

It will not escape notice that in the last two quotations there is both a general reprimand for all those who do not sympathize with the saga and a definite complaint about a "tuneless contemporary age."

An important trait of Fosforos is its sympathetic attitude toward contemporary publications of saga literature in Denmark. The December number for $18 \mathrm{IO}^{1}$ contains an announcement of the publication of the Nial Saga (Historia Niali et Filiorum. Kiobenhavn, I809) and makes a brief but intelligent comparison of this saga with the works of Snorre Sturleson and Saemund Frode. The annual for $18 \mathrm{II}^{2}$ announces, again, a "worthy" complement to the Nial Saga in the Egil Saga in Latin translation, published with notes and chronologies by the same famous Arne-Magnussen Foundation. The editor believes the Egil Saga to be a real contribution to the history of Sweden, Denmark, England, and Norway, and the fact that the hero was both "skald" and "berserk" appeals to him particularly. Then we obtain an idea of the customs of the olden time, its art and commerce, its laws and administration of justice. In short, he finds a "remarkable amount of culture" in the Egil Saga, the events of which took place in the tenth and eleventh centuries. ${ }^{3}$ Then, with a sincere effort for philological accuracy and style, the editor goes on to give information about codices and to name forerunners in the field. Lastly, he ventures the hypothesis that the manuscript is from the thirteenth or fourteenth centuries, "when Ore Frode, Snorre Sturleson, and Sturle Thurdsen constituted the golden age of Icelandic literature."4 The beginning of a critical study of

\footnotetext{
1 Ibid., pp. 380-r.

2 Ibid., pp. 69-70.

3 Ibid., p. 69.

4 Ibid., p. 70.
} 
the sagas makes its appearance also at this time in Fosforos. Concerning the above mentioned monuments, published in Denmark, Carl C. Gjörwell sent a contribution to Fosforos dated in Stockholm, January IO, I8I I, ${ }^{1}$ which consisted of a few biographical and historical data about Egil and Nial. Gjörwell takes a broad and thoughtful view of the sagas; there must be sympathy for them as literature, he believes, and the historical facts must be taken cautiously. Yet we must attach some historical importance to these tales. All Norse sagas are "not merely ballads to amuse simple-minded people. ${ }^{2}$

To come back to Atterbom. The leading Romanticists paid tribute to the saga element in creative poetry as well as in literary criticism. Atterbom writes to Hammarskjöld, January I4, I8I I : I have now read Oehlenschläger's "Digte," first edition, and a few of his romances have strengthened my opinion still more that a national (egen) Scandinavian poetry is possible. Perhaps you will soon see your friend attempt this new path. Later on I should like to write a text-book on mythology like Moritz's, but I shall not be able to devote myself to Icelandic literature diligently for a couple of years to come. More about this may appear in print."3 The public did not have to wait long for something in print on Norse mythology from Atterbom's pen. In the very Prolog to Fosforos, in that strophe which is addressed to his fatherland, Atterbom calls his countrymen "sons of Thor,"4 and Fosforos for I8I I is introduced by "Skaldarmal,", a direct creative

1 Ibid., pp. $157 \mathrm{ff}$.

2 Ibid., p. 160.

3 Frunck: "Bref rörande den nya skolans historia," IV, p. 217. Ochlenschläger's "Digte" had appeared in 1807 . Moritz was Karl Philip Moritz (1757-1793), Professor in Berlin, and author of "Götterlehre." In a letter to Hammarskjöld, dated February 4, I8II, Atterbom again refers to his intended work on Norse Mythology: "I have not yet touched my intended Norse Mythology. I cannot hope for a realization of this plan before I get time to devote a couple of years exclusively to this work." See Frunck: "Bref," IV, p. 229. On the other hand, Palmblad does not believe that Atterbom's Norse Mythology will ever see daylight unless "God deigns to prolong his life by eighty years." .Frunck: “Bref," IV, p. 235.

4 Cf. the last two lines of the strophe:

"Och Thor än sina söners berg bestrålar,

Der skalden dina nya under målar!"

5 Fosforos for I8II, pp. 3-8, followed, pp. 8-14, by explanatory notes. 
tribute to Scandinavian mythology. The mere existence of this poem is well known, but the exact nature of its contents or importance is generally ignored. It is a Romantic plea for a national poetry on the basis of indigenous saga-material. It is at once a glorification of poetry and of the saga age which the poet is to bring back, and a pessimistic characterization of the present era. The poet deplores the existing lack of interest in the runes and complains that feeling is silent in "our desolate days." "What will ye do, ye old rune-tones (runoljud) with a people who have no sense of honor, or with a world which has no God?"1 The poet regrets that the harp which Brage played in days of yore at wedding feasts sounds no more in Northern forests. ${ }^{2}$ And so he sings of battle, Valkyr, and Valhalla; of the viking and the skald; of Thor and the giants, of Frigga and Balder; in short, of the age when "beauty embraced strength."3 Allusions to the weird norns and the bewitching song of the water-sprite (necken) help to complete the picture. There is great enthusiasm for skaldic poets or, to use Atterbom's own term, "bragar," and their art. "The heart was given for the fatherland, and if you but love the dead as we do, you will lure them back with the magic of song." "Skaldarmal" is written in strophes, in tetrameters, interspersed in the second and fourth lines with trimeters, and with the rime-formula: $a b a b c c$.

"Skaldarmal" is followed immediately by what is more important than the poem itself: namely, by notes on the Norse mythology employed, and these notes, it seems to me, fix pretty definitely Atterbom's temporary position relative to Old Norse literature. The notes betray a knowledge of what had been done before in this line, and reveal a conscientious study of the myths; they are illuminating and, for the most part, correct. And they must have been accepted by the public as unusually trustworthy interpretations, not only then, when everybody was more or less ignorant of the subject, but later, when poets and scholars were better acquainted with Scandi-

1 Ibid., p. 3.
2 Ibid., p. 5.
3 Ibid., p. 5.
4 Ibid., p. 7 . 
navian mythology. When, in I8I5, four years after the Goths had appeared above the horizon, a dictionary of Norse mythology was published in Nyköping, several of Atterbom's notes to "Skaldarmal" in Fosforos, even the incorrect ones, were copied word for word in it. ${ }^{1}$ It stands to reason, then, that Atterbom acquired some reputation by his genuinely national poem and its accompanying notes; that some ${ }^{2}$ influence must have been exerted on his contemporaries, even if he cannot be given credit for inaugurating the Gothic Society or its publication, Iduna. ${ }^{3}$ That this Fosforist tried to arouse enthusiasm for the saga element, however, before the actual organization of the Gothic Förbund or the appearance of its literary organ, cannot be denied, and the influence at first, if any, went from Fosforist to Goth and not vice versa. To say unconditionally that the impulse for the historical "revival in Swedish culture, was given by the Gothic Förbund" ${ }^{4}$ is incorrect.

But, to leave the matter of influence and chronology, let us examine the notes themselves more in detail. Atterbom's remarks are to serve, not only as a guide to his poem but also to indicate, by way of anticipation, the spirit in which a perfected Edda, possessing a symbolism of its own, could be produced for Norse art. ${ }^{5}$ Atterbom declares emphatically that the demi-sagas of the Edda are not a positive evil, the product of a stupid imagination. ${ }^{6}$ Then he waxes enthusiastic again and

1 See Svensk Litteratur-Tidning for I8th of May, 1816 (No. 20), p. 313.

2 Cf. below, first paragraph of Chapter III.

3 In the recension of the first number of Iduna, in Forforos $181 \mathrm{I}, \mathrm{p}$. $177 \mathrm{ff}$., Atterbom rather proudly assumes credit for having given the impulse for such a publication. (Cf. below, p. 40.) This has given rise to many useless attacks by his enemies. The dispute is pretty well settled, and it would not be very important if it were not. Norling ("Nya skolan," p. 67) has given the most sensible opinion about this matter: "Of course, Iduna would have been born without Atterbom's exhortations, but it would be just as wrong to deny this, as to assert that the Fosforists' love for the fatherland received its first right trend from the latter" (Iduna). The fact that the January-February number of Fosforos for I8II, which contained "Skaldarmal," appeared a little late (see p. 96 of Fosforos 1811), makes no appreciable difference of chronology.

4 Vedel : "Svensk romantik," p. 25 I.

5 Fosforos, I 811 , p. 9.

6 Ibid., p. 12. 
queries whether the "ideal principle of poetry had not appeared with greater force in Sweden (Svithiod) than in Hellas," whether "our ancestors' wisdom and poetic art, bred under the same sky as we and upon the unchangeable foundation of the same North," did not stand closer to us than a foreign Southern art. In fact, Atterbom takes a concrete example, finds that "the wonderful teachings about creation and its final destruction" are, "from a philosophical view-point, most important in the Edda." In other words, not only the Scandinavian patriot, but the philosopher, had better go to early Scandinavian literature for his fundamentals.

Atterbom is a thorough Romanticist all through his notes. At times he seems verbose and misty, as in his interpretation of creation, but, above all, he is philosophical and symbolic, and compares briefly the characters from Norse mythology with those from Greek, Latin and Oriental myths. The influence of Tieck and Novalis is also noticeable. Atterbom describes Freya, the goddess of beauty, as follows: She was "the symbol of love and hope, a composition of infinite music and ardent longing, and, like Aphrodite of the Greeks, she had sprung from the water." Freya was the daughter of Necken, the genius of music, who was said to live in the water, and of Skadi, the symbol of disturbance in the elements. Necken under the name of Ägir (Neptune) and Niord (Eolus) were worshipped as the rulers of water and wind respectively. ${ }^{2}$ Idun (Iduna), the goddess of youth, wife of Brage, the god of fine arts, becomes to Atterbom the embodiment of poetry, the symbol of immortality, and corresponds to Hebe of the Greeks. ${ }^{3}$ Balder, the god of innocence, piety and light, becomes furthermore a "symbol of virtue in its original form." $\mathrm{He}$ is killed by Loke, the personification of the "original evil," and corresponds in some particulars to Apollo. ${ }^{4}$ Frey, the god of fertility on earth, becomes to Atterbom the "symbol of enjoyment (Bacchus), who loves man and gives abundance to nature." ${ }_{5}$ Thor

1 Ibid., p. 13.

2 Ibid., p. 12.

3 Ibid., p. 10.

4 Ibid., p. II.

5 Ibid., p. I2. 
represents the sun, and is a "symbol of the masculine principle of the Deity, light, or reason, which fertilizes the natureelement (Naturgrund) or the original imagination, unites (as in marriage) the form and content and thereby becomes the origin of the real creation." $1 \mathrm{He}$ is the god in human form, the mediator between man and God, the redeemer among our forefathers and corresponds to Vishnu and Christ. He occupies the highest throne in Uppsala temple and has assumed greater prominence than Odin, for he (Thor) is visible. Similarly, Frigga or Disa represents the moon and is a symbol of the feminine principle of the Deity, materia. She is the wife of Allfather, Odin, and represents the Fate which is united to Providence, the motherly in the universe, and necessity in nature. She corresponds to the Egyptian Isis, to the Ephesian Diana, and to Mary in the Christian religion. She is a symbol, also, of the divinity of the earth as Mother-of-all, hence like the German Hertha. ${ }^{2}$

We have stated above that Atterbom's notes were, for the most part, correct. Yet, the characteristic lingo, such as we found in the note on Thor, is not always as clear as it might be, and it is therefore difficult to determine whether they are correct or incorrect. That some of them were actually incorrect was discovered by the reviewer of the dictionary of Norse mythology in $1815 .^{3}$ But it is a strange fact that the more Atterbom's interpretations are studied the more the modern student will agree with him, and the more Atterbom's ideas seem to fit into an intellectual system. As far as the symbolism goes, we feel that Atterbom has at least a justification for his own Romantic point of view. Yet it is doubtful whether Frey, as the god of productiveness, of rain, and sunshine, and as the patron of all crops, ${ }^{4}$ is the Norse analog of Bacchus, who was the "symbol of enjoyment" in a more specific sense. Again, Atterbom makes Necken identical with Njord. But Njord is one of the fourteen full-fledged Asa-gods, mentioned in Snorre's Edda (Gylfaginning), whereas Necken is a lower

1 Ibid., pp. 9 ff.

2 Ibid., p. 9.

3 Cf. above, note I, p. 34, and text on pp. 34-35.

4 Cf. Sundén: "Översikt av nordiska mytologien," Femte upplagan, p. 8 o. 
spirit, an elf-like water-sprite of the smaller bodies of water, and is more the product of popular superstition. In his commentary on Thor, Atterbom assumes that other Norse gods were invisible and lacked human form. But to all of the genuine Asa-gods, human form was attributed: "To them (Asadivinities) are attributed human form and human conduct, but all on a higher and nobler level.",

But it must be added to Atterbom's credit that he tried to be self-critical in his analysis of Norse myths, became conscious later of his youthful shortcomings, acknowledged his mistakes, and was ready to rectify them. He writes to Tegnér, July 20, I8II: "In the notes to the above-mentioned poem ("Skaldarmal'), I made a couple of historical mistakes, which will be corrected in my next experiment in this line."'2 Atterbom sought modestly to approach Tegnér by means of his first "experiment." He sent the first number of Fosforos for I8I I to his more distinguished colleague and wrote: "I have there (in the beginning of the first number) ventured the first outline of a revival of the extinct myths of Sweden, and am certain that this new idea will interest you, ${ }^{3}$ whose muse long ago began to charm us with Northern delight. I considered it unworthy that we should ignore our own forefathers' sacred remains, in a journal which is intended to embrace the most important objects for the culture of a growing literature. Whether any clear pictures can be developed from my shadowy lines, is a problem which can be solved only by you and your peers." 4 Tegnér, who believed in Atterbom's poetic ability, ${ }^{5}$ received his "Skaldarmal" favorably. Atterbom writes: "Your (Tegnér's) estimate of $\mathrm{my}$ 'Skaldarmal' has pleased me heartily

1 Ibid., p. 19.

2 "Ur Esaias Tegnérs papper," p. 39. He does not state the precise nature of the mistake, however.

$3 \mathrm{~A}$ free translation. Atterbom addresses Tegnér in the third person with "Tit." "title," implying a repetition of all titles every time he addresses him. For the sake of simplicity I have rendered this "Tit." by "you."

4 See letter of April 19, 1811. "Ur Esaias Tegnérs papper," p. 38. As it happened, Atterbom here addressed, prophetically, the very poet who, fourteen years later, was to solve the problem in "Frithiofs Saga."

5 Cf. Letter to Geijer of February 17, 1811. Jubelfestupplaga. V, p. 65. 
and has, together with the approval of my friends and many of my enemies, encouraged me to make further attempts later in the same style and tone." ${ }^{1}$ But Tegnér, who hated anything philosophical, had evidently objected to the Fosforistic interpretation of the myths, for Atterbom continues in the same letter:

"À propos of your view of my method of interpretation of Norse mythology and my Schellingization ${ }^{2}$ of the same, I venture only to recall that the fundamental principles of nature-philosophy ${ }^{2}$ gleam forth, though enveloped in a more or less perfect mythical dress, through all the mythologies (guda-systemer) which betray an evident relation to the Hindu mysteries, and this in a stronger or weaker degree, according to their distance from the maternal source. Take the eternal element of the Trinity; do we not find it in any mythology which has the least claim to speculative importance or deep religiosity? But with all this, I by no means have the presumption to force upon you the conception of an unripe youth; on the contrary, I am willing to admit that the doctrine of nature-philosophy still needs development in several points."

It is clear that, although Atterbom expressed his intention to correct objective historical mistakes in his notes, he clung to his independent, philosophical interpretations with persistent tenacity. To Atterbom the Norse myths are often, not so much a living religion or the symbolism of a living people, as our ancestors thought them to be, but rather an indigenous source for a new, national poetry, where the spirit and philosophy of the myth are more important than the objective divinities. This explains some of the freedom which Atterbom took with his objective facts. In a letter dated April 23, I8Ir, Atterbom first declares to Hammarskjöld that he has read the Edda, and then answers an evident criticism of his own notes to "Skaldarmal" by the Danish philologist Grundtvig:

"In spite of what Grundtvig may say to the contrary, I do not believe that he possesses a very clear vision for the inner structure

1 Letter of July 20, I8II. “Ur Esaias Tegnérs papper," p. 39. Nothing more followed, though, in exactly that "style and tone."

2 Cf. above: Thor represents the sun; Frigga the moon and the necessity in nature, etc. 
of hyperboreism, ${ }^{1}$ if he does not believe that Thor is the genius of the sun. I have made (in my notes) many other bold combinations, for example between the water-sprite and Freya. ${ }^{2}$ I do not aim at a dead correctness to the letter; my purpose is to discover the lost fantasy of the North." 3

And listen to the following:

"That Thor, without the knowledge of the Gothic populace, represented the supporting and mediating power, whose glory we imagine most beautiful in the form of the element of light, does not seem to be refuted by the story of Skinfaxe and the daughter of Mundelfare. ${ }^{4}$ The meaning is not that Thor had his seat in the sun, but that the sun in certain Beziehungen ${ }^{5}$ was an image of his majesty;-In other particulars, you look at my treatment of Norse mythology from my point of view: namely, not from the antiquarian (view-point) but from the poetic. ${ }^{6}$ For me it is not a question of how the people in this or that age looked upon their dogmas-it is very likely that they did not reflect much about their meaning and continuity - but how a complete whole in Northern Geist ${ }^{5}$ may be formed out of this crude mass; how this united whole may become a fitting costume for a living national poetry, which is not only sung from the chamber of one literateur into that of another, but can seize the Swedish heart with Swedish songs."?

1 "Hyperboreism" seems to have been a septentrionalized system of nature worship in which Atterbom dabbled to a considerable extent. The sun seems to have been the emanating center of this system. To me, it is a good illustration of some of Atterbom's so-called explanations.

2 Cf. above, p. 35 .

3 Cf. Frunck: “Bref," IV, p. 285. Atterbom's purpose is, indeed, ambitious and pretentious.

4 Skinfaxe (Icelandic, Skinfaxi) was the horse of Dag (Icelandic, dagr), whose mane illuminates air and earth. Here was apparently a contradiction to Atterbom's view that Thor was the genius of light, and attention had been called to it. The daughter of Mundelfare (Icl. Mundelfoeri) was Sol (Sōl). Having been placed in the sky, she drove the steeds which pulled the chariot of the sun. Cf. Sundén: Översikt av nordiska mytologien, pp. 8 and 9. Here was a discrepancy in gender, for Sol is a feminine character in Norse mythology. Could Thor, then, be the symbol of the sun? Note the explanation of Atterbom.

5 The German words are in the Swedish original.

6 We get a glimpse here of Hammarskjöld's temporary attitude towards Norse myths, but we shall see later that Hammarskjöld had a very conservative idea about introducing it into Swedish art and poetry.

7 Letter by Atterbom to Hammarskjöld, dated "Uppsala am Walpurgisabend I8I1." Frunck: “Bref," IV, pp. 29 I-2. 
The success of "Skaldarmal" and the justified reputation acquired by its unique notes gave the author a feeling of what came dangerously close to presumption. Consequently, when the first number of Iduna appeared, there followed an enthusiastic review in Fosforos by Atterbom, in which the honor of incentive goes to "Skaldarmal." At least, I do not see how there can be another plausible interpretation, and, undoubtedly, critics have had some justification for attacking the insinuation in the following extract from the review:

"That prophecy which resounded in our 'Skaldarmal,' concerning the return of Norse life to thought and song, and that appeal to the geniuses of Sweden which was expressed there and in several places in this periodical, is no longer a happy dream, it has not been made in vain." ${ }^{1}$

But Atterbom's pleasure and enthusiasm were not entirely selfish; he was happy for the sake of Sweden that the Gothic organ had appeared. He sees great hopes now for Swedish art and investigation of antiquity. In Geijer's immortal lyrics, such as "The Last Skald " (Den siste skalden) and "The Last Warrior" (Den siste kämpen), he detects the character of "Swedish magnanimity," a pious love for the heroic age of Sweden and-as a Romanticist-the holy aspect of art which through imagination is the highest herald of religion and ethics. "The Viking" (Vikingen) is "a Gothic romance," a masterpiece wherein we find the reflection of a simple honesty, a genuine expression of the true, original (ursprunglig) Norse nature; it is not dead antiquarian learning. "The Last Warrior," the reviewer finds, has a commendable ancient rhythm, and the bard improvises in "The Last Skald" in verse which is closely akin to Icelandic. Geijer had made frequent use of new imperfects, such as "klungo" for "klingade" and "svang" (Ger. schwang) for "svingade." This appealed to Atterbom, not only because Geijer here stood on German feet, but because the new forms were old. Atterbom adopts his customary method and compares, briefly, the Norse myths with those of

1 Fosforos, I8I r, p. 177. Cf. above, note 3, p. 34. For whole review, see pp. I $77 \mathrm{ff}$. 
India and Greece. He looks at his Scandinavian ancestors here from an historical, political and ethical standpoint also. His forefathers were fighters because fighting was, historically, a part of their moral and religious conviction; the old Goths had a "restless fighting virtue and faith in warlike gods." And, he avers in his spirit of a Rousseauite, if the (political) states are to become what they once were, the age of mythology must return. ${ }^{2}$ In the recension of the Swedish translation of Nyerup's Edda, ${ }^{3}$ Atterbom says he has been "pleasantly" superseded by Iduna and lauds the thorough description in it of the relation between superstition, myth and religion. Here, however, our Fosforist has a tendency again to become philosophical and obscure. In regard to translations from the Icelandic he is sensible and self-critical; he admits willingly his own linguistic limitations. He says very little about these for he confesses too great a weakness in Icelandic to compare them intelligently with the original, ${ }^{4}$ and this in itself is a feature of Atterbom's interest which points in the right direction.

We have described the nature of the interest in the saga element in Fosforos, as it was exemplified in the leader of the Fosforists, Atterbom. It consisted (I) of enthusiastic reviews of modern Scandinavian literature based in any way on Scandinavian antiquity, (2) of sympathetic announcements of saga literature which had appeared in Denmark, and (3) of an original poem by Atterbom, accompanied by a detailed and philosophic commentary on Norse mythology. Henceforth the last of these three drops out; i. e., there is no more original "Gothic" poetry by a genuine Fosforist. In 1813 Forsforos died and was replaced by another annual, Svensk Litteratur-

1 Fosforos, 1811 , p. 183.

2 Ibid., p. 183.

3 Nyerup's Edda had appeared in Copenhagen in 1808 . It was translated into Swedish by Jakob Adlerbeth and published in Stockholm, 1811. In regard to Nyerup's Edda, Atterbom writes to Hammarskjöld, February 4, 1811 : "If Nyerup's Edda is for sale in Stockholm, buy a copy for me à tout prix." See Frunck: "Bref," IV, p. 229. And, again, on May 5, I8I I, to the same friend: "It pleases me beyond description that Adlerbeth's Edda has appeared. Would to God that it were only here." Frunck: "Bref," IV, p. 301. There is no lukewarmness about such expressions.

4 Fosforos, 1811 , p. 182 . 
Tidning. In this organ the interest in the saga age is limited to announcements and reviews. That Atterbom did not write another "Skaldarmal," as he had intended to do," must be due, in part, to his activities along other lines of his cult, and to the appearance of other literary men and women, most of them members of the Gothic Society, who now sought to cover this national part of the field. And so, for the present, the future historian of Swedish literature began to lay the foundation for his "Swedish Seers and Skalds" (Svenska siare och skalder) by a systematic study of old Scandinavian monuments, the fruits of which could only appear very much later. He fostered the Gothic movement, temporarily, by a consistently expressed sympathy and by the writing and editing of occasional reviews.

As an illustration of the "consistently expressed sympathy," I need only cite the Fosforists' abiding attitude toward Iduna, as we find it in Svensk Litteratur-Tidning, and for which Atterbom and Palmblad are jointly responsible. And it was not a lukewarm, polite formality, for politeness in literary matters at the time was out of fashion, but it was a real interest. The same policy adopted by Fosforos was continued in its successor. The review of the fourth number of Iduna, for instance, is extremely favorable: "With warm and hearty joy the reviewer announces a new number of this excellent periodical, which has contributed so much to awaken a love among our countrymen for our ancestors' hardy era, and has called attention to the only means whereby it might return with higher potency." Then the Gothic organ is eulogized for its "manly enthusiasm" for all that is good and beautiful, and is criticized intelligently at great length. When the second edition of Iduna for I8I I had appeared, Svensk Litteratur-Tidning came out at once ${ }^{3}$ with a retrospect of Iduna's work. The former numbers, we are told, had had better original poetry, but the more recent ones more valuable results of antiquarian investigations. Eulogistic adjectives like excellent (förträfflig) and superb

1 Cf. above, pp. 37-38, and note $I$.

2 Svensk Litteratur-Tidning for October 23, I813, No. 42.

3 November 13, 1813, No. 45. 
(ypperlig) are plentiful and give the tone of the résumé. The fifth number of Iduna is hailed by the Fosforists' organ as a "precious gift" which has again been given to the public," and the sixth number ${ }^{2}$ as a "useful" contribution. In the same organ for $18 \mathrm{Ig}^{3}$ Iduna is mentioned as one of the periodicals of the New School, and the eighth number ${ }^{4}$ is characterized as the "clearest celestial signs" which appear on the contemporary horizon of Swedish letters; the reviewer is afraid he cannot find anything blameworthy in the "Fragments of 'Frithiofs Saga' which now appeared in Iduna."

And not only Iduna but all of the important Gothic productions received an almost disproportionately large amount of attention in Svensk Litteratur-Tidning. It is this generosity of space devoted to reviews of national poetry that I wish to emphasize. The review of Ling's "Gylfe" (edition of I8I2, Lund) runs through three numbers (No. 8 of February 27; No. Io, March I5; No. I2, March 27, I8I3), and that of "Gefion," by Fru d'Albedyhll, two numbers (numbers 23 and 24 for June II and I8, I8I4). Granberg's "Jorund" is lashed for maltreatment of saga sources through two numbers (numbers 20 and 21,1814 ), and Geijer and Afzelius get two numbers full of commendation for their folksongs in 1815 (numbers 45,46 , for II th and I8th November). Count v. Skjöldebrand gets due attention for an heroic poem in ten songs, entitled "Odin." Rask's review of Hammarskjöld's publication of the Jomsvikinga Saga appears in number 14 (April 5) for I8I7, the number for May 3 (No. I8) of the same year contains a review of eight songs of Ling's "Asarne" by the same eminent Dane, and Ling's "Eddornas sinnebildslära" is honored with $3^{1}$ pages (pp. 545-575, numbers 35 and 36 ) in 1820 . The editors are very generous, also, in the space allotted to announcements of books on Icelandic topics, or to translations

1 October I, 1814 , No. 39.

2 July 6, I 816 , No. 27.

3 P. 44I.

4 Reviewed in Svensk Litteratur-Tidning for 1820 , pp. $769 \mathrm{ff} ., 785 \mathrm{ff}$. , $80 \mathrm{Iff}$. and $8 \mathrm{I} 7 \mathrm{ff}$.

5 Stockholm, 1816. Reviewed in Svensk Litteratur-Tidning, No. 48, for November 30 , 1816 . 
from Old Norse. ${ }^{1}$ Finally, in 1824, four numbers (57-60) are devoted to the recent dramatic works of Ling. ${ }^{2}$

It would be futile to give a review of all these recensions; the fact that they are there in conspicuous length is what is important for our purpose. It will be seen, however, that after about 1813 the nature of the study of ancient Scandinavian culture necessarily changed, even for the Fosforists. What had appeared in print before that time had been more a study and eulogy of Norse mythology in general and a rather indefinitely focused enthusiasm for all former ages; now, when individual sagas began to be translated or employed as the basis for poetic experimentations, the attention of the critic had to be concentrated on specific mythical or heroic sagas. The reviews, therefore, become scrupulously critical and exhaustive. For example, in Atterbom's somewhat prejudiced criticism of Granberg's "Jorund" (which we shall treat in detail in the next chapter) a great deal of the unmerciful attack is directed pointedly against the distortion of the historical Jorund as described in the original source: the Ynglinga Saga by Sturleson. This called for specific information. But we shall see that Atterbom had more than kept up with his contemporaries, was well prepared to review any saga-product that might appear, and certainly knew more about the individual sagas than some of those who used them in their poetry. And so his criticisms become real, erudite supplements to the original, and in some cases he adds valuable material which has no direct bearing upon the specific topic treated. This is the case with his abovementioned recension of "Gefion" by Charlotta d'Albedyhll, which tells us as much, if not more, about Atterbom than it does about the authoress of the original poem. ${ }^{3}$

1 Cf. review of Afzelius's translation of "Edda Saemundar hinns Froda," pp. $65 \mathrm{ff}$., 97ff. Review of G. G. Liljegren's edition of "Svenska fornåldrens hjeltesagor," pp. 1 29, 209, 24I, 593, and (3) review of "Svenska folksagor," edited by $\mathrm{H}$ (ammarskjöl)d and I(mmeliu)s, Stockholm, 1819, pp. 449ff. All these in annual for I8rg.

2 "Blot-Sven," "Injalld Illråda," "Wisburs Söner" and "Styrbjörn Starke."

3 Cf. next chapter, where analysis of "Gefion" is given. 
This review, ${ }^{1}$ which I shall take as an illustration, is prefaced by an exposition of the transition from Scandinavian literature in general to the beginning of Swedish literature in particular. It is the preface that I desire to mention here, as showing Atterbom's progress in his studies of early Scandinavian literature and history. As in "Skaldarmal" the tone of regret for a contemporary lack of interest in primitive Sweden is present here also, but it is a regret in the light of historical development. The original "Norräna-language" was preserved among the "republican and historically-minded Icelanders of Iceland," while Christian sentiment destroyed almost all traces of heathenism in Sweden. ${ }^{2}$ The old letters disappeared probably before the language, yet the sound of "Gothic drapa" (drapa, a song of praise for a king) did not cease to vibrate in Sweden until after the middle of the fourteenth century, when Birger Jarl and his son, Magnus Ladulas, reigned, and when their courtskald Sturle Thordarson lived. ${ }^{3}$ But from now on the old language was not understood. Swedish had become isolated and independent, no more skalds appeared in Sweden, and Icelanders stayed away for the very reason that they could not be well understood. The Ynglinga-dynasty died out in Norway in 1319 , and then after the passing of the Norräna-Skald the knowledge of the Old Norse sagas in Sweden became hazy. The Danes had Saxo, who wrote an invaluable historical work in Latin, which, in spite of its faults, is as accurate as we can expect from a Catholic clergyman. ${ }^{4}$ But the Swedes had no Saxo to collect material where such was to be had, and so it was not until the middle of the seventeenth century that they knew anything about their ancestors' life and art, except that they were "blind heathens and worshipped three idols, whose names were Thor, Odin, and Frigga." Then Atterbom criticizes previous historians; Lagerbring was really the "father

1 Printed also in Atterbom: “Litterära karakteristiker," Örebro, 1870, pp. II5-135. References will be made to this edition, which is more accessible.

2 Cf. ibid., p. 115.

3 Ibid., p. I 6.

4 Ibid., p. I 18.

5 Ibid., p. I 19. 
of Swedish history," but had no sense for mythology and poetry; Von Dalin was superficial, misunderstood these, and soon led others astray, so that antiquarian and fantastic pedant became synonymous terms. ${ }^{1}$ In this same preface Atterbom pays tribute to the work of Verelius and Rudbeck the Elder, of the seventeenth century, showing that he had already commenced the foundation for his later exhaustive characterization of these men. ${ }^{2}$

But Atterbom is still a typical Fosforist and after seven pages of history there follows an introductory eulogy ${ }^{3}$ of the authoress of "Gefion" and her art, in a language which in spirit reminds one strongly of the Prolog in Fosforos. It is a mixture of Fosforism and Gothism. There is talk of the "heavenly ability of poetry" and the idea is set forth that the sanctum sanctorum of man, the "pure feeling of the eternal, is expressed in the genius of music." Therefore, why should not daughters of these [ancestral] heroines follow the example of their mothers when "maternal sound of harps has returned to their mountainous region" (fjellbygd). We must cope with Germany and Denmark unless we wish to feel ashamed of ourselves. Iduna (the goddess of eternal youth; wife of Brage, god of poetry) had returned to Sweden, "the golden shimmer of her rejuvenating apples has begun already to beautify the new dawn of Sweden's internal independence." 4 The spirits of the Norräna-song descend into their former sacrificial groves, "and so it ought not to astonish (us) if the women of the North share the flame which $\mathrm{Urda}^{5}$ has lit in the hearts of Northmen. They have not forgotten that their mother Freya was generated by the element of yearning ${ }^{6}$ or that her relatives, the maidens of the sea, praised the blissful secrets of the wave with string-instrument and song." Then after mention of Brynhilda, Aslaug, and Gudruna, he finally gets to the criticism.

1 Ibid., p. 12 r.

2 Cf. pp. 19-20 of Introduction.

3 Ibid., pp. 1 2 I-2.

4 Ibid., p. 121.

5 Urda generally conceived as the Norn of the Past. But see Sundén: Översikt av nordiska mytologien, p. 22.

6 See above in characterization of notes to "Skaldarmal," p. 35. 
In true scientific style Atterbom gives first the complete original of the Gefion Saga, ${ }^{1}$ and gives it correctly. He makes now a sharp distinction between pure mythology and saga, and pronounces "Gefion" more allegorical than historical. He calls attention to the mistake of confusing Allfather with Odin. Odin was the son and instrument of Allfather and was limited in time and space. He was the product of Fjolner (the concealed) and Fimbultyr (the incomprehensible divinity). ${ }^{2}$ Much, again, is made of the myth of Freya; she is the allegory of Northern love, and then the Romantic idea is set forth that poets are chosen as interpreters of "inner models of love." The tone of the whole review is extremely flattering; Atterbom lauds the fervor of the authoress for arousing interest in the Asa-myths in Sweden, and praises the first song of "Gefion" as a complete masterpiece, consisting of scenes and groups which together "form the most beautiful picture that Swedish poetry up to this time has given of Northern mythology." 4 It is interesting to note that Atterbom defends the superabundance of kings and nobles in the poem. Most of us would like to claim counts and kings as ancestors, is the frank opinion of Atterbom, and he has little respect for those that would not. ${ }^{5}$

One evidence of Atterbom's interest in the saga element is his increasing study of Fouque and enthusiasm for his "Sigurd der Schlangentödter" (1808). This evidence we find in Atterbom's reviews in Svensk Litteratur-Tidning. In connection with the form of "Gefion," Atterbom adds: "Fouque has by mighty efforts already proved the possibility of fulfilling the requirements of Icelandic verse-structure. Its wonderful rhythms, assonances, and alliterations possess a bewitching power which now resembles the Dwarf-mal (mal, song) of mild valleys, now the roar of storms and mountain torrents, mingled with the clang of swords against the shields of Val-

1 See Ynglinga Saga by Sturleson, Chap. 5.

2 Sundén gives the meaning of Fimbultyr as equivalent to God of the runes and attributes this quality to Odin himself. See "Översikt," p. 30. 3 " Karakteristiker," p. I 35.

4 Ibid., p. 127.

5 Ibid., pp. I30-I. 
kyrs." ${ }_{1}$ In another review, ${ }^{2}$ Atterbom compares the French classical tragedies of Corneille and Racine with the treatment of Norse sagas by Fouqué: "What can that kind of tragedies and epopées, of which the French boast so much, furnish to the Scandinavians, who possess a primeval antiquity which has descended from gods, and who possess heroic sagas with such a wealth of tragic depth and inner beauty in their composition, that no race on earth can show anything comparable? Take all such works as those of Corneille (Corneillerier) and Racine (Racineader) put together: What are they in comparison with a single Völsunga-and-Niflunga Saga, treated by Fouqué!"3 Again, in connection with his recension of the eighth number of Iduna; "Why is this heroic drama (hjeltespel, meaning 'Sigurd der Schlangentödter'), the most powerful and most beautiful of all Fouqué's works, still so little known among the youth of Sweden? Neither this nor its Urtext, such as it is found in the Völsunga Saga in Björner's 'Norse Tales of Combat' (Nordiska kämpadater), should be missing on the book-shelf of anyone who claims to have a spark of love for Northern literature and poetry."

In the annual Poetisk Kalender (1812-1822), edited chiefly by Atterbom, there are several poems of strictly national character, but not many which deal with the Scandinavian sagaage. The viking element is incidental, and is general rather than specific. No individual Icelandic sagas are dealt with, but motifs are often taken from indigenous popular tradition or saga and assume, then, a ballad-like character. Such is Afzelius's metrical romance "Var-Ulfven," the story of a lover who must pass fifteen years in the "dark forest" as a wolf $\left(\right.$ ulf $\left.^{5}\right)$, and is based on a folk-saga from Southern Sweden.

1 Ibid., p. 133. Atterbom refers, of course, to such imitations of the highly diversified Icelandic verse-structure, as are found interspersed in "Sigurd."

2 Review of "Svenska akademiens handlingar ifrån år 1796. Femte delen."

3 " Karakteristiker," p. 198.

4 Ibid., p. 266, and note. The modern critic, I think, would hardly agree with Atterbom that Fouqués "Sigurd" is more beautiful than "Undine." The exaggeration speaks for itself.

5 Poetisk Kalender for 1813 , pp. $37 \mathrm{ff}$. 
Atterbom sings of a proud mermaid who captures a sweetheart of the shore, ${ }^{1}$ Julia Nyberg (Euphrosyne) invents a historical romantic ballad on the basis of an inscription upon a newly discovered runestone, ${ }^{2}$ and in "The Viking Maid" (Vikingstärnan) the heroine sees from the shore her lover Ivar find a grave in the waves and then joins him. ${ }^{3}$ Often the interest in antiquity takes the form of a poetic eulogy of those who have treated Old Norse material in some substantial way. The Kalender for $18 \mathrm{I}_{5}$ contains two sonnets; one is entitled "The Last Runestone" (Den siste runstenen) and, from what we are told in a note, ${ }^{4}$ is an indirect tribute to the Swedish antiquarian Rudbeck (the Elder) and Verelius; the other, "Gefion," is, of course, a direct recognition of the abovementioned Eleonora Charlotta d'Albedyhll. "The North" (Norden) from the German by Amalia v. Helvig, and put into Swedish by G(umaeliu)s, is steeped in northernism, Swedish superstition, and Norse mythology. ${ }^{6}$ In "Upon the Heights of Uppsala” (På Upsala högar), dated May I5, I816, Atterbom seizes the opportunity for a solemn poetic reflection upon old times, when the maiden "went up in flames hand in hand with her bethrothed." In some lyrics, terms from Norse mythology are employed merely for external ornamentation and color; such are "Freya's Spinningwheel" (Freyas rock), by Hammarskjöld, and "The Warrior in the Northern Forest" (Kämpen i nordanskog), by Inge-1-gre-n. ${ }^{8}$

1 "Hafsfrun" in Kalender for 1813 , pp. $69 \mathrm{ff}$.

2 Cf. "Skattgräfvaren och brudsmycket" in Kalender for 1820, pp. 89ff., and note, p. 89.

3 Kalender for 1821 , pp. $54 \mathrm{ff}$.

4 Andra upplagan, p. 69 . It is signed $\mathrm{S}^{++}$.

5 Ibid., p. 90 , signed H. R.

6 Kalender for $182 \mathrm{I}$, pp. $24 \mathrm{Iff}$.

7 Kalender for 1817 , p. 80; Poem, pp. 79-8r.

8 Kalender for 1812 . Tredje upplagan, pp. 58-59, and annual for 1813 . Tredje upplagan, pp. 65-67, respectively. "Freyas Rock." "Rock," apparently for "Spinnrock," is the name of the constellation Orion in southern Sweden. See note, annual for 1812 , p. 58. The last strophe of Hammarskjöld's poem is a good example of Norse dress :

Sant Bröder! Förstummad är Baldurs mun,

Och mer dricker Odin ej Mimers brunn

Och Valhallas murar de störtas i kras;

Men Freya hon spinner ännu. 
In an honest, straightforward, confessional preface to the second edition of Poetisk Kalender for I812-1813, dated June 9 , I8I6, we have further evidence of Norse sympathies. Atterbom himself is there speaking of his past encouragement from a small circle of literary sympathizers: "This circle existed, it expanded, and soon Iduna appeared, which showed even the more skeptical that the foundation for the re-birth of the new culture lies in the original Swedish sense of kinsmanship. ${ }^{1}$... The spirit of our pious, simple folksongs, as well as of our gigantic heathen monuments (urminnen), begin at last to be comprehensible, even to ourselves, since they have long been so to our kinsmen. ${ }^{2}$ Novalis, Tieck, Oehlenschläger, and Fouque have introduced us into their magic world of eternal love and unwithering youth, of loyal heroic power and victorious renunciation.",

In Poetisk Kalender for I8I7 we get an interesting glimpse of a somewhat different phase of Atterbom's Norse studies. This volume contains "The Songs of Selma" (Sångerna $i$ Selma), a "Fantasy from Ossian." They are not translations, but rather free adaptations in Swedish. These are followed immediately by twenty pages ${ }^{4}$ of remarks on the character and problems of Ossian, and deal briefly with the viking element in the Ossian poems. In so doing, he takes issue with Macpherson in a matter of chronology. According to AtterbomI am only giving his views-Fingal must have lived "at or shortly after, the days of Harald Fairhair" (863-936), ${ }^{5}$ and bases his claim upon chapters 20 and 22 of the Heimskringla by Sturleson. It was during the reign of Harald Fairhair that the many viking expeditions and emigrations to Iceland, Scotland, and the Orkney Islands took place. "Harald himself conquered the Orkney Islands, ravaged the coast of Scotland,"6 and went as far as the Isle of Man; and Sigurd, the Earl of the Orkneys, took possession of Caithness and Sutherland.

\footnotetext{
1 Poetisk Kalender for $1812-13$, Tredje upplagan, p. iv.

2 Ibid., p. xvii.

3 Ibid., pp. xvii-xviii.

4 Ibid., pp. 30-49, for I 817 .

5 Ibid., p. 43.

6 Ibid., p. 44.
} 
"One knows that these islands for a long time were under the dominion of Norway; but not until the reign of Harald Fairhair (see Saga, Chap. 20) were they discovered and settled, as was Iceland, by mighty emigrating races." 1 These are the historical facts as Atterbom gives them to us, and he follows Sturleson religiously. ${ }^{1}$ Now, in view of these facts, Atterbom reasons-and it must be admitted plausibly - that before this time (of Harald Fairhair) Fingal could not have lived; because the Orkney Islands and those islands situated between Scotland and Norway are in Ossian controlled by worshipers of Loduinn (Odin), who seem plainly to stand under the supreme rule of the kings of Scandinavia (Lochlin), or at least in immediate relation with Lochlin."'2

Atterbom took an interest in folklore. Following the example of Brentano and Arnim in "Des Knaben Wunderhorn," and encouraged by the examples of his fellow-countrymen, Geijer and Afzelius, whose folksongs had begun to appear in I8I4, Atterbom published a collection of folk-lore in Poetisk Kalender for 1816. The group of songs itself is, to be sure, not very remarkable and it is not a large group. The two divisions of ballad-like "romances" and those of a more distinctly lyrical character occupy only II 9 pages in a pocket-size volume. Nor are they very important for us, since the oldest romances are taken from the fifteenth century and the pure "songs" are, for the most part, from the comparatively modern period of Gustavus Vasa (I52I-I560) and his sons and from the seventeenth century. ${ }^{3}$ But, as we might expect from Atterbom's usual method, his collection is prefaced by a lengthy discourse on European and Scandinavian folklore, about the sources of his own songs, about the fundamental differences between Northern and Southern poetry, and about the perfectly natural

1 The exact time of Harald's western voyages, however, is not known, I think. Iceland was discovered in 863 , the date of Harald's ascension to the throne of Norway, and was being colonized eleven years later. Harald is said to have undertaken his expedition about 880 , or a little later. Cf. Hildebrand: Translation of "Heimskringla" (Konungasagor), p. 5, note 2 , and p. 63 , note 1 .

2 Kalender for 18 i 7, pp. 43-44.

3 See Förord (Preface) to Poetisk Kalender for 1816, p.x. This preface is dated December 20, 1815 . 
transition from Norse heathenism to Christianity in Scandinavia. The treatment of these songs often leads our enthusiasm back to primitive times. Then, almost imperceptibly, he makes digressions and tells us incidentally (I) of his early studies of the sagas, (2) of what we may call his Rudbeckianism, (3) of his later intentions along Gothic lines, (4) and of the forebodings of Christianity in Norse mythology. These indisputable testimonies from Atterbom himself need no discussion; I desire simply to present them here as such and I shall illustrate these four points by quotations in the order named.

(I) "The genius of skalds granted that my birth took place in a remote woodland. Here, from the very time I lay at my mother's breast, I grew up among sagas and songs, and from my third year, when the first book was put into my hand, to my tenth, when I for the first time left my parents' home, I seldom had any other company outside of them than those characters I got from Sturleson and Verelius, mingled with Corneille's heroes and the dreams with which I populated my horizon in great numbers." 1

(2) We see in the second paragraph of his preface that Atterbom likes to think, like Rudbeck the Elder, of "the polar regions, consequently Scandinavia also," as the "primitive home of all the inhabitants of the earth and the historical seat of the celebrated (allbesungna) golden age."2 Again, in speaking of the folksong:

"Among all the Gothic (i. e. Germanic) nations the consciousness finally awakened that they in origin, temperament, and language are only one people; that the North, the mother of all modern history, which from the beginning of the migrations to the present time, has created all that is great and eternal on earth, does not receive a foundation and a definite outline for her majestic ideal of a completed temple of art and literature, until she has bathed herself in the youthful spring of her primitive life," etc. ${ }^{3}$

This needs no further comment, either with respect to involved form or super-patriotic content, except that this Rud-

1 Ibid., p. xli.

2 Ibid., p. iii.

3 Ibid., pp. xxvi-xxvii. 
beckianism did not seem actually to mar Atterbom's critical estimates of literature or history in other respects.

(3) In order "that the readers of Sweden (male and female) may in a clear consciousness grasp the nature of the North's, of Sweden's original feeling (känslosätt), of the indestructible character of the race, I deliver this simple wreath of the Northern flowers (i. e. folksongs) into their hands. [And I do this] with the hope of being able soon to produce a richer collection from the Icelandic saga-world, and any favor for the sake of the holy couse, will encourage me and my friends upon our mountain-paths."1

This hope was realized later, at least in part, by his translations of Edda-songs which are incorporated in "Svenska siare och skalder."

But to turn (4) to a more important testimony in this preface. Atterbom's attitude toward Norse mythology here is neither superficial nor fanatic, but thorough and sensible. He sought the spirit and inner truths of these myths, and looked upon them as upon sacred forerunners of Catholicism. He wished, above all, to see their native spirit introduced into a national poetry and did not mean to introduce the external heathen culture bodily, as seemed to be the intention of some of the more radical Goths. "It is not my intention, as many seem to think, to re-introduce either the Asa-doctrines or Catholicism, either seriously or as external dress (uniformvis), as some of Sweden's recent poets employ our ancestors' myths and names of divinities."2 But Norse myths possess an intrinsic value, in Atterbom's opinion, which in sublimity surpasses other religious systems. Because of its Oriental origin and its development among the people of a powerful race, it "forbodes, most profoundly of them all, the coming and significance of the universal religion which descended to us from heaven in Christ."3 In what Atterbom calls the "night-of-

1 Ibid., p. xxxix.

2 Ibid., p. xxvii. This whole theoretical problem of introducing Norse mythology into Swedish poetry is discussed in Chap. III to which I refer.

3 Ibid., p. xxviii. The contemporary belief that the Asa-religion was Oriental in its origin would not prevent a Rudbeckian, it seems to me, from believing that Scandinavia was the cradle of civilization. Atterbom seems to have believed both, in modified form. But about four thousand years 
northern-lights" (norrskensnatten) of the Voluspá must be seen the "aurora of the days of the gospel," in order to see the wild beauty of Valhalla and not of the wildness alone. What is true of Norse mythology is also true of its history. The world of Christianity was developed from "this terrible warrior-strength" of the viking age, Balder was replaced by the person of Christ, Allfather took Odin's place, the vikingexpeditions became crusades, and Freya becomes not only the goddess of earthly love but the symbol of eternal goodness."1

Referring in particular to the glory of the Holy Virgin and her symbolic position in Catholicism, Atterbom writes:

"One must understand the scattered forebodings (aningar) of this glory in the sagas about Frigga and Freya, the latter of whom was represented as delivered over to demonic influences and vices, and constantly searching for her consort, i. e., as a burning and unsatisfied longing, in order to understand, even in this case, the transition from heathenism to Christianity, from the viking period to the age of chivalry."2

One must also-and this is significant of Atterbom's progress in the study of the genetic development of Swedish cultureunderstand these sagas in order to comprehend "how the Northman-spirit in all changes has been essentially the same, in every-day life, in religion, and in song, and how each change has taken place merely to prepare a higher development of this inborn unity."'s

Such was the character of Atterbom's interest in the Old Norse element during the Romantic period. To be sure, Atterbom did not carry out all his good Gothic intentions along creative lines, and sometimes his enthusiasm carried him too far in mere rhetorical praise of national material; but, after all, he made a conscientious effort to know and to further the knowledge of Scandinavian sagas. He knew more about the sagas than the majority of the Goths and was, therefore, a real elapsed between the traditional date of creation and the immigration of the Asas into Scandinavia, which is supposed to have taken place during the last century B. C.

1 Ibid., pp. xxviii-xxix.

2 Ibid., p. xxxi.

3 Ibid., p. xxxi. 
"Goth." He admitted shortcomings and mistakes in concrete facts, but clung stubbornly to his own esthetic interpretations. $\mathrm{He}$ was an antiquarian, but a poetic antiquarian and a philosopher. He was, primarily, a lover, interpreter, critic, and historian of Norse myths; not so much a creative artist. In his theoretical views of Scandinavian myths, Atterbom is in danger of exaggerating the value of their meaning, but his theory about their introduction into Swedish poetry is sensible. Their power, symbolism, and spirit are the essentials, and he is inclined to believe that these internal characteristics are even preferable to those of Greek mythology.

What we demand for Atterbom is not unwarranted eulogy, but honesty and justice; a realization that even his early interest in the sagas was something more than a mere prédilection $d$ ' artiste. Many of his contemporaries were loath to admit this at first, and so his work was underestimated and good influences were often lost sight of in the din of polemics. But after the literary battles of the Fosforists had been fought, a kind of peace declared, and the final reckoning came, some glory had to be awarded to Atterbom while he was yet alive. That his friends recognized his ability is natural. Palmblad, in his biography of Ling, refers to Atterbom as "a friend who was at home in Old Norse monuments and who was especially good in remembering them."1 Geijer ends his treatment of the Gothic society, in the last number of Iduna, with an expression of gratitude to Atterbom. And let us put Atterbom himself on the witnessstand again, taking the testimony of the defendant for what it is worth: Ling saw finally to his agreeable surprise that in Sweden he could hardly find anywhere "a more animated study (betraktelse), a warmer sympathy for the Northern saga-and-heroworld," than among those with whom he was once dissatisfied, i. e., among those who sympathized more with southern verseforms, i. e., the Fosforists. ${ }^{2}$

It is a curious irony of fate that the most radical Fosforist

1 See Biografiskt Lexikon, Vol. 8, Uppsala, r841, p. 274.

2 Cf. Atterbom: "Pehr Henrik Ling. Inträdes-Tal i Svenska Akademien den 29 Maj. 1840." Printed in "Minnesteckningar och tal." Senare bandet. Örebro, I869, p. 43. 
became the successor in the Swedish Academy to the most radical Goth, Ling, and, as such, became his biographer and critic. ${ }^{1}$ In Atterbom's inaugural address on Ling, we find a splendid proof that the early saga interest of Atterbom had been genuine: he has continued his Norse studies, he has actually read the colossal epic "Asarne" (918 pages)-most contemporaries did not-and now gives a final, mature estimate of Ling. But Atterbom is still, in I840, a Romanticist; a poetic esthete who looks up to Norse mythology with religious reverence. In this respect Ling could never have found a more worthy successor. Atterbom believes absolutely that our Norse forefathers' $W$ eltanschauung was founded on a religious principle which was belligerent in its essence. He observes that even war may be a religious meeting especially when waged against the powers of darkness. ${ }^{2}$ And he places the vikings under this category. They must often have appeared to him as celestial emissaries, and the tragedy of their lives was merely a mirror of the lives of the gods. ${ }^{3}$ Norse mythology is a "hero-religion."

"Throughout the heroic life there was a religious meaning infused. The same war which the Asas in the invisible world carried on against the giants and the trolls, was carried on by their human analogs (afbild), the inhabitants ... ruled by the Asas, against the uncivilized tribes who, in their savagery and in their gloomy wilderness, represented the palpable counterpart of the giants' home or Jotunheim."4

Atterbom, then, had retained practically the same theoretical view of Norse mythology for thirty years, ever since he began to edit the Fosforos, infusing into it an extraordinarily deep spirituality and meaning. The vikings then became the apostles of this extraordinary religion, and as such he thought that some of their bloody escapades might be excused. It is not our intention to describe further our Fosforist's activity in this line;

1 Every candidate upon election to membership in the Swedish Academy must prepare and, upon his official entrance, give a public address upon the life and works of his predecessor. Cf. preceding note.

2 Cf. "Inträdes-Tal," p. 45.

3 Cf. ibid., pp. $48 \mathrm{ff}$.

4 Cf. ibid., p. 48. 
what Atterbom did later as a mature historian of Swedish literature is well known. But let it be emphasized here that the introduction to "Swedish Seers and Skalds" contains fifteen chapters (2I7 pages) on the history of primitive Sweden, on Scandinavian myths and on the spirit, content, and metrics of Icelandic literature. Another chapter (Chap. I7) is devoted to folklore. And the foundation for it all had been laid while Atterbom was a militant Fosforist.

Atterbom was not the only Fosforist to be moved by the Norse spirit. As early as the fall of 1803 , seven years before Fosforos appeared and two years before Atterbom became identified with the new literary coterie, the Friends of Belles-Lettres $^{1}$ (Vitterhetens Vänner or V.V.) exhibited Gothic tendencies. At a meeting of these "Friends" in November 1803, Per Neurling (1783-I856), a student at Uppsala, gave a short address on the literature of the old Goths. "The main purpose (of this literature), according to the speaker, was to praise the deeds and battle-fire of the heroes, for which reason the skalds also were highly respected and important men who dwelt at the king's courts."2 Now, concerning Meurling's remarks we have a significant comment by Lorenzo Hammarskjöld, whose attitude toward Old Norse literature is next to be considered. Hammarskjöld, who was one of the charter-members of the V.V. and next to Atterbom the most prominent of the Fosforists, writes to Livijn, Nov. 22, I803: "Last Sunday we [the members of the V.V.] had a meeting. [After speeches by two other members there] came finally Meurling's address on the literature of the Goths, which I liked almost the best. The style in it was so manly.",

Again on March 2, I806, Hammarskjöld writes the same friend: "While I have been here (in Thomestorp, Östergötland) I have studied the Hervarar Saga and the saga of Har-

1 Cf. Introduction, p. 5. Atterbom became a member of this literary circle in the fall of 1805 . He was the last youngster to receive an election. Cf. Hjärne: “Dagen före drabbningen," pp. xx-xxi.

2 Cf. ibid., p. xlvi. Hjärne adds the comment that we obtain here "a glimpse of that spirit which fully developed gave life and character to the Gothic Society and its literary activity."

3 Cf. Hjärne : as above, p. 40. 
raud and Bose. The former especially is rather beautiful. Hjalmar's death-song is truly elegiac. ${ }^{1}$. . . Angantyr's discourse, after he has murdered his brother with the deadly sword Tirfing, is a masterpiece. It is comparable to the chorus in a Greek tragedy.",

As a matter of chronology, then, the bitter antagonist of the old school, Hammarskjöld, read Icelandic heroic sagas at least seven years before the Gothic Förbund was formed, and even before he was associated with Atterbom. In a review of Oehlenschläger, published in the Lyceum for I8Io, we again find traces of a national tendency. ${ }^{3}$ But this tendency in Hammarskjöld is, after all, conservative and limited. The sagas found favor with him, in part because they were little known and were not French. Busy with his Gallophobia Hammarskjöld was prone to superficiality and haste, so that his work in the saga-field is spasmodic and of questionable value. His publication of the Jomsvikinga Saga, ${ }^{4}$ in which Rask found several mistakes, and the collection of folk-sagas in I8r9 was of no great consequence. Tegnér had no sympathy for Hammarskjöld whatsoever, and not one iota of faith in his ability. In fact, Tegnér goes to the other extreme and in his estimate becomes severe and unjust. When the Gothic Förbund sought to import an Icelander to stimulate the interest and work in Old Norse, Tegnér expressed the hope to Adlerbeth that the sagas would not land in Hammarskjöld's hands, who understood neither Icelandic nor Swedish. ${ }^{5}$

A study of the letters in Frunck's collection throws some light on Hammarskjöld's early attitude toward Old Norse literature. It seems undecided and inconsistent. Hammarskjöld certainly did not possess that constant enthusiasm for the Gothic Danes

1 Hjalmar is killed in combat with Angantyr. See Chap. 5 of Hervarar Saga which contains also his death-song.

2 Cf. Hjärne: "Dagen före drabbningen," p. 232. The date of the letter is given there as 1804 , but this is a misprint corrected on the last page.

3 Cf. Malmström: "Svenska vitterhetens historia," IV, p. 370.

4 Cf. above, p. 43. For Rask's recension see Svensk Litteratur-Tidning for April 5 (No. 14), I817.

5 Cf. letter to Adlerbeth of April 19, I818. Tegnér: "Skrifter," Jubelfestupplaga, V, p. 150. 
that Atterbom possessed. He writes to Livijn, October I, I8IO: "In the meantime I took a trip to Copenhagen, but could not endure it more than a week. The Danes are undoubtedly the worst of all flesh-eaters (köttätande varelser) that God has created. They are absolutely nothing but imitators and their coarse Germanomania is tenfold more unsavory than the Gallomania of our own worthy countrymen." 1 From two letters by C. A. Agardh (r785-I859) to Hammarskjöld, we learn that the latter was interested in Norse mythology but objected to its use in modern poetry. ${ }^{2}$ And yet he thought it depended upon the method of treatment and upon who treated it. His friend $\mathrm{Li}$ vijn, who was contemplating a drama on Odin, is encouraged thus: "I cannot but wish you firmness in your decision and tenacity of purpose with respect to your 'Odin,' although I do not understand how you can obtain dramatic unity in this subject." 3 The national tendency of Atterbom is also, of course, applauded by Hammarskjöld. He writes to Livijn, September I2, I814: "You are right, Atterbom is the soul of the new sect and the one of all its members who has decidedly the truest calling. To be sure, he cannot become a Goethe or a Tieck for the simple reason that every genius must remain himself." . . . $\mathrm{He}$ is "too much of an ardent Christian to compete with Geijer for Brage's oak-leaf wreath, ${ }^{4}$ although, from my view-point, the dead Norse myth must be treated as in that truly beautiful 'Skaldarmal,' if anything of importance is to remain of the whole experiment." In another letter to Livijn, December I2,

1 Frunck: “Bref," III, p. 146.

2 Letters of December 6, I810 (III, p. I75), and February 2, I81 1 (IV, pp. 227-28). The precise nature of Hammarskjöld's answer must be based on a letter from Hammarskjöld to Agardh. This letter, however, is not published by Frunck and I have been unable, as yet, to learn whether this letter is in existence. The other occasion for Hammarskjöld's objections to the employment of Norse myths in poetry was his review of Oehlenschläger's "Poetiske skrifter" in the first number of Lyceum. I have been unable to obtain a copy of this short-lived paper. Only two numbers ever appeared, one in 1810 and another in the following year.

3 Letter of April 15, 18 1 I, IV, p. 278.

4 Referring, of course, to Geijer's bardic (or oak-leaf), Viking-Ossianic, national poems in the first number of Iduna.

5 Frunck: "Bref," V, p. 35 I. Hammarskjöld himself, though, had used the names of the Old Norse gods as a poetic dress. Cf. above, page 49, note 8 . 
I8I I, we see that Hammarskjöld kept well posted on plans for future publications in Gothic circles and welcomed their appearance. Very soon there was to appear "an excellent translation" of the Hervarar Saga (by A. A. Afzelius), a new number of Iduna, Ling's "Gylfe," etc. ${ }^{1}$

Hammarskjöld did some work for Iduna of a philological and historical character. In the second number there appeared a description of a manuscript of the prose Edda, dated November 5, I8II. Another article by Hammarskjöld, dated March 5, I8I4, appeared in the fifth number. This article is entitled "To the Editors of Iduna, Concerning Fr. Rühs's (of Germany) Recently Published Treatise on the Origin of Icelandic Poetry." Rühs ${ }^{2}$ had attacked the age and genuineness of the sagas; he had attempted to prove a Christian origin for Norse mythology, a wholesale borrowing from Greek and Roman myths, and held that Icelandic was, to a large extent, borrowed from the AngloSaxon. ${ }^{2}$ In answer to this contention, Hammarskjöld comes out with an unmerciful attack on Rühs and with a strong, patriotic and enthusiastic defense of the Norse myths. Hammarskjöld is wild with excitement to think that anyone should attempt to steal his own mythology. Shallow as it may seem, an extensive and thoughtfully evolved mythological system is sufficient proof to Hammarskjöld for the human origin and original development of the Scandinavian languages. ${ }^{3}$ And how could Norse literature have a Christian origin? Would a Christian monk furnish models for pagan poems? ? $^{4}$ ith great pride Hammarskjöld refers also to national manners and customs which originated in Norse mythology, points out that it is an integral part of the Volksglaube and not a later interpolation. Incidentally we notice some effort on the part of Hammarskjöld to master Icelandic at this time. He has had under his care

1 Frunck: “Bref,” V, p. 397.

2 Christian Friedrich Rühs (1781-1820). Rühs's article, which had appeared the year before (1813), bore the title: "Ueber den Ursprung der isländischen Poesie aus der angelsächsischen, nebst Bemerkungen über die nordische Dichtkunst und Methodologie, ein notwendiger Anhang zu den neuesten Untersuchungen."

3 Iduna, No. 5, p. Ior.

4 Ibid., p. 105. 
(in 18I4)-and this is important-“" Icelandic manuscripts from various ages " for eight years, ${ }^{1}$ but detects no similarity in letters between Icelandic and Anglo-Saxon, although he has had a manuscript, the Codex Aureus, in front of him.

Hammarskjöld was something of an antiquarian also. In the same number (5) of Iduna, we find in a note (p. 54) to an article on ancient "Funeral Mounds" by P. W. Tholander, that Hammarskjöld had in 1812 personally investigated or counted fourteen such funeral mounds near Tuna Sätesgård in Calmar Län.

Hammarskjöld's early attitude towards Norse antiquity seems, then, to be something as follows: he has a real interest in it, he welcomes publications of heroic sagas and studies them and their manuscripts, but is skeptical about the use of Norse myths in Swedish poetry. If they are to be employed at all the author should follow the channel designated by Atterbom in his "Skaldarmal," that is, the myths should be used merely as poetico-symbolic embellishments, or as a basis for reflection upon Scandinavian antiquity. But Hammarskjöld is a staunch, patriotic supporter of the genuineness of these myths. Let antiquity remain antiquity, however, do not attempt to recast it and reintroduce it bodily into modern literature. Contemporaries accused him of inaccuracy and dillettantism. In his judgments he is inclined to be prejudiced and influenced by the personal element of friendship or animosity. His theoretical views are rather conservative, a fact which is better illustrated in his attitude toward the introduction of Norse myths into plastic arts.

This attitude is found expressed in Hammarskjöld's last lecture on the history of art. $^{2}$ The classical conception of the universality of art is the predominating tone. A very injurious prejudice, according to Hammarskjöld, is the slavish imitation of the antique in order to obtain the beautiful.

"And yet," says Hammarskjöld, "on the other hand, I am just as violently opposed to the idea of those who advocate such a severe

1 Ibid., p. 9r. Hammarskjöld does not state, however, how much he has studied them.

2 Cf. below, p. 103 and note 3 . These lectures were given in the spring of 1814 and were repeated in the spring of the following year. 
nationalizing, that the commendable in Swedish art is restricted to that which a Swede only can understand. This is the right way to fall into mannerisms. Art is, on the contrary, like virtue, truth and faith, the property of all humanity, and its purpose is precisely to destroy all national and statistical boundaries and to unite the various kinds of peoples into one single race. And it is just as certain as the sun shines that the artist who has received the allpower of genius can make a Zeus or an Apollo ... without destroying the given type... just as Swedish as a Thor or a Blader."1

Whether we agree with Hammarskjöld in this particular or not makes little difference here. We cannot deny the universality of plastic art, but whether a Swedish Zeus would be as Swedish as a Thor or not is at least open to doubt. That a national art based on Norse myths, was possible (see Chap. III) was proved later. But the important point here is that Hammarskjöld warns diplomatically against exaggeration in either direction and thus anticipates, in one way, the attitude of Geijer in $1817 .^{2}$

Hammarskjöld's later interest in the national field does not differ materially from his early interest. There is seldom any of that consistent Atterbomian enthusiasm and the personal element and prejudice are still in evidence. But in Hammarskjöld's work as an historian of Swedish literature, there is discernible a greater friendliness toward the Goths and an effort for more thorough scholarship. His "Swedish Literature" (Svenska vitterheten), where he gives an account of the work that has been done in Old Norse literature, ${ }^{3}$ is, to be sure, prejudiced and unscientific yet he is not blind to shortcomings in translations and poor codices, which shows an effort toward correctness if not an actual accomplishment.

The articles on Swedish literature from I800-1828, which Hammarskjöld wrote in German for the Leipzig Hermes in

\footnotetext{
1 Hammarskjöld: "Utkast till de bildande konsternas historia." Stockholm, i817, p. 441 .

2 Geijer warned against exaggeration in the use of Norse myths in art in "Betraktelser med afseende på nordiska myternas användande i skön konst." Cf. below, Chap. III, pp. I 2 off.

3 See second edition by P. A. Sondén, pp. $178 \mathrm{ff}$.
} 
I823-I824, are unusually interesting and illuminating for our study of this phase of Hammarskjöld's activity. He lashes P. A'. Granberg for his "Jorund" as unmercifully as does Atterbom. He calls the criticism by the Swedish Academy, which had honored Granberg for his tragedy, "trite,"1 and believes that "Jorund" can serve as a model for the way a tragedy should not be written. ${ }^{2}$ The feeling against the Academicians, then, still prevails in this Fosforist, even if, as we shall see later, Granberg deserved some of the adverse criticism. Tegnér he calls rightly the most important author in Sweden, but thinks he may be praised too much and admonishes readers to remember that he is a product of his time. ${ }^{3}$ Later our historian speaks very favorably of Iduna; he calls "Frithiof" by Tegnér "excellent," recognizes the popularity of the Gothic organ, and terms its poems "glorious." " Afzelius is a special favorite of Hammarskjöld. After speaking of his work in the Eddas, Hammarskjöld says: "He has collected and edited the old, wonderful folk-romances with noble diligence and patience." Charlotta d'Albedyhll's "Gefion" does not get the same enthusiastic reception from Hammarskjöld as it did from Atterbom. $\mathrm{He}$ admits that the form is beautiful, but declares that " the character of the little epic is neither heroic, nor romantic, gnomic, religious, nor idyllic, but high-aristocratic, in order to eulogize the family of the authoress by a mythical origin."' The Goth Geijer gets the comparatively large space of four pages ${ }^{7}$ in Hammarskjöld's necessarily brief treatment, but the critic is interested mostly in Geijer's philosophy. The national "Agne" by Ling becomes a "fatalistic drama," written in the antique style, with a "large number of the most glorious songs in it," but "Eylif den Göthiske"s written by the same author after

1 Hermes, Leipzig, I823, No. XVII, p. 249.

2 Ibid., p. 250.

3 Ibid., pp. $255-56$.

4 Hermes for 1823 , No. XX, p. 355 .

5 Ibid., p. 305.

6 Ibid., p. 306.

7 Ibid., pp. $321-25$.

8 Both "Agne" and "Eylif den Göthiske" are now published in Vol. 2 of Ling's Samlade arbeten. Cf. below, Chap. III, note 5, p. Io3. 
the French style in Alexandrines, is "the worst." As a Romanticist Hammarskjöld hopes that Ling will soon finish his work on the symbolism of the Eddas (Eddornas sinnebildslära) ${ }^{1}$ and in his next article he lauds the system, thoroughness and deeper significance of the Eddas, which are now expounded in Ling's work. ${ }^{2}$ The comment on Count von Skjöldebrand's "Odin "3 presupposes some knowledge of the original source. Hammarskjöld has discovered that Skjöldebrand has followed the historical Saxo more closely than the Eddas, hence the characters are more men than gods and excite greater sympathy in the reader. On the other hand, this process-and notice the Romanticist here again-has drawn the author "from the charm of the wonderful.".4

Hammarskjöld had an unmistakable admiration for popular poetry and in his introduction to "Svenska vitterheten" he praises Afzelius, Geijer and Atterbom, who published collections of folksongs after models in Germany, England and Denmark..$^{5}$ Here is sympathy, then, for the genuinely national. But Hammarskjöld did some actual work in this line also. Geijer in a note to his article on "The Old Norse Folksong" (Den gamla nordiska folkvisan, I8I4) states that he has Hammarskjöld to thank for several notes on popular poetry. ${ }^{6}$ And in Svensk Litteratur-Tidning for March 27, 1813 (No. 12), we have an article by Hammarskjöld himself on old Swedish folksongs. He dwells on their importance for the study of the language and thought of the olden peoples, and for the development of the romantic art of poetry in the Scandinavian countries. He gives characteristics and titles of manuscripts of Swedish folksongs that have come under his observation. It is of some consequence to note-and this is the justification for this paragraph-that Hammarskjöld urges a collection of these

1 Hermes for 1823 , No. XX, pp. 330-31.

2 Hermes for 1824 , No. XXII, pp. 20I-2. Cf. below, Chap. III, p. 104. “Eddornas sinnebildslära" was published in 1819 . It remained a fragment.

3 See above, p. 43.

4 Hermes for 1824 , No. XXII, p. 212.

5 Cf. second edition, published by Sondén, p. I7.

6 E. G. Geijer: Samlade skrifter, Stockholm, I874-76, I, p. I49. 
folksongs a year before the Goths began the publication of them. Hammarskjöld writes: "It is about time that we follow the example of our kinsmen, the Englishmen, Germans, and Danes, and collect and publish these oldest relics of national poetry in which the primitive individuality is expressed so powerfully and often so beautifully."

From an historical and chronological standpoint there is no member of the New Romantic Movement who can serve as a better illustration for us than another charter member of V.V., a friend of Hammarskjöld, and later a leading contributor to Polyfem, Clas Livijn. The attitude of this young, interesting enthusiast toward the Norse saga is a natural one, and in many ways typical of his contemporaries, even among his own literary circle. It is the attitude of any would-be revolutionist toward a new movement. At first, it is not felt as decidedly patriotic, but as a poetic protest against French classicism and the Academicians. Then, later, when this tendency had assumed a more definitely national character, and was in danger of becoming ridiculously national, the shafts were often turned against the new Gothic mania. Not against the principles of the Gothic movement, be it noted, for the Fosforists were in sympathy with them, but against exaggerations in the practice of them. This was not done by Atterbom, but it was done by several of the other Romanticists. Hammarskjöld, as we have just seen, was opposed to an extreme nationalizing tendency, ${ }^{1}$ and later (see below, Chap. III.) Vitalis and Dahlgren poked fun at it. This is the case with Livijn. We detect from the first a genuine interest in the sagas, with ambitious plans for two dramas and two operas based on them, but in the middle of the second decade, when the Gothic Förbund began to assume an alarming character, Livijn ridiculed its extreme tendencies and especially its member Ling.

The period of Livijn's active interest in Old Norse material covers about a decade, beginning in 1803 . In an undated letter

1 Cf. above, pp. 61-62. Cf. also Sterner: Den nordiska mytens användning $\mathrm{i}$ bildande konst. Stockholm, 1881, p. 38. In Svensk Litteratur-Tidning for 1818 , No. 49, Hammarskjöld criticises severely recent plastic productions, both of the Old and the New School. 
from I803, Livijn writes to Hammarskjöld: "I have now made the plan for a drama, 'Gyritha.' The theme is from Saxo Grammaticus. I intend to send it in (to V.V.), although it is yet uncertain, since I have not written anything upon it." 1 In a following undated letter he sends the plan of his intended three-act play to Hammarskjöld. The drama, however, was never finished and only a part of the first act was ever written. In another undated letter, undoubtedly from the middle of December, $1803,{ }^{2}$ we learn that the first act was completed and that Livijn himself was pleased with it, but says that "Gyritha" has reverted to its darkness and will probably never receive a place in the learned world through me. ${ }^{3}$ In the same letter we learn that Livijn is reading English and Danish authors and is particularly interested in their Norse themes. He has not seen any "happier imitation of the Old Goths" than Gray's "The Bard" and "The Descent of Odin." Both, and particularly the former, possess a Pindaric loftiness and the strong, unbending character of the Northman. O, how charming is the bard's address to the king! You could imagine the sound of Ossian's harp calling down all misfortunes upon a wicked king and celebrating in song the fallen heroes! Ewald in the Valkyrs of his "Balder" has left us an imitation of his (Gray's) "Fatal Sisters," which is undoubtedly poorer than Gray's.4

A couple of years later, November 8, I805, Livijn has another plan in mind. Again he confides in his friend Hammarskjöld: "I am pondering a great deal over an opera, where I could introduce our Northern divinities, and where all ballets, changes, etc., should be produced by visions" called forth by witchcraft à la 'Macbeth.' Here it is Norse mythology and Shakespeare which hover in Livijn's mind simultaneously, and the prospective author is seeking an harmonious union of Old

$1 \mathrm{Hjärne:} \mathrm{Dagen} \mathrm{före} \mathrm{drabbningen,} \mathrm{p.} \mathrm{49.} \mathrm{Mortensen} \mathrm{puts} \mathrm{the} \mathrm{date} \mathrm{of}$ this letter December 1,1803 . See Clas Livijns dramatiska författarskap, p. 62 , note $\mathrm{I}$.

2 See Hjärne: Dagen före drabbningen, p. 59. (See note.)

3 Ibid., p. 62.

4 Ibid., p. 62.

5 Ibid., p. 202. 
Norse content with Shakespearean method. In the beginning of 1806 he seems to have found a subject for his intended opera. He is to study all possible Gothic sagas, because he has his "head full of plans for an opera"; " Balder's Death,' rimeless, and in the same meter that you find among Icelanders. As far as possible I want it Gothic and not Quinaultic. You know that the Goths sang in violent passion against one another. On this point see any one of the sagas." 1

Livijn considered the old Icelandic sagas an essential part of Swedish antiquity, in which respect he resembled Atterbom, and so, in answer to a letter from Hammarskjöld, ${ }^{2}$ Livijn commends his friend warmly for studying the old saga material: "That you have studied the old Gothic sagas pleases me so much the more, since that shall be my foremost study in time. I find it indefensible that our literary practitioners neglect entirely the ancient Swedish literature." ${ }_{3}$ There could be no saner or more national thought expressed anywhere than is expressed here in this champion of the Fosforists. A plan of Livijn to study the "Gothic" language (here Icelandic, of course) was soon to be realized, at least in part. His friend Hammarskjöld was an assistant at the Royal Library in Stockholm, and Livijn hoped through his help to gain access to the treasures of the library and acquire enough critical knowledge of Icelandic to be able to express his "thoughts clearly and in Swedish concerning the poetry of the Goths." "I have now commenced to study old Gothic," Livijn writes; "it is a divine language, but I see that I cannot acquire the perfection which is necessary to translate such products correctly, before midsummer." 4 In other words, Livijn planned translations from Icelandic poetry and expected to acquire the requisite proficiency in the language in about two months. It was a bold and commendable plan, even if not feasible.

As a Fosforist, Livijn took a sympathetic interest in Gothic publications, was acquainted with past editions of the Eddas,

1 See undated letter to Hammarskjöld, probably from February, I806, in Hjärne, pp. 226-27.

2 Letter of March 2, 1806.

3 Hjärne: Dagen före drabbningen, p. 233.

4 Ibid., p. 237. Letter written in April, 1806. 
and was very enthusiastic about the coming translations of the Edda by Adlerbeth. He writes to Hammarskjöld, February 23, I8II :

"You cannot imagine how pleased I am at Adl(erb)eth's enterprise, in which I wish him good luck with all my heart, because I am certain that his work will be good. What I wish is that he might have chosen Sturleson's Edda, and preferably the Uppsala copy of it, on account of its Skalda-Kenninga, which as far as I know do not exist anywhere else. The reason is that we possess already both a rather good translation and the original of the Saemund-Edda by the Arne-Magnussen Foundation. You will do me a real favor if you let me know which one of the Eddas he follows and if the original text is included. This work will certainly produce a kind of epoch in our literature, when it makes the public acquainted with the literary products of our antiquity."1

Then, in this same letter, Livijn anticipates the danger which might arise from an abuse of these literary products and expresses the hope that Academicians like Markall (Wallmark) and Struthio (Wallin) will not, for want of other originality, concoct out of them a sort of Swedism which, "beyond a doubt, would be more distasteful than our neighbors' Danism."

Livijn's estimate of Atterbom's "Skaldarmal" is a good example of Gothism plus that prejudiced eulogy which one Fosforist was wont sometimes to give another. The tone is that of youthful Schwärmerei, expressed in a realistic, not to say naturalistic, style:

"At last, after several attempts, I have obtained a copy of Fosforos. "Skaldarmal" is above all commendation. You can easily imagine what I feel from the description; I already know it by heart; I walk back and forth on the floor, spit and snap my fingers, and repeat one tirade after another in a loud voice." ${ }^{2}$

"Skaldarmal" represented, then, for the present, both to Hammarskjöld and to Livijn, the national poem, par excellence, where Old Norse content and modern form were in harmony.

1 Frunck: "Bref," IV, pp. 242-43.

2 See letter to Hammarskjöld of July 13, I8Ir. Frunck: "Bref," V, p. 317. Livijn refers, of course, to the January-February number of Fosforos for I8II. 
A month later (August I4, I8II) he has re-read his copy of Fosforos. He has found several poems which are "the product of a true inspiration" and of these "Skaldarmal" is mentioned first. He cannot praise it enough and believes the notes to "Skaldarmal" excellent. Atterbom's real purpose as a poet is not yet fully developed, though, Livijn believes, but "perhaps it will pass over into a striving for that primitive Norse spirit which is revealed in all Oehlenschläger's work." ...

In the same letter we get (I) a personal estimate of the Edda, (2) of Nyerup's edition of it, (3) additional commendation of Adlerbeth's undertaking, (4) the doctrine of Gothism as a cure for the contemporary insipidity in literature, (5) a warm welcome to Iduna, and, lastly, (6) some of Livijn's curious views on the influence of Christianity in Sweden. Livijn writes:

"In my opinion the old Edda has a kind of dark and solemn tone, combined with the simplicity which appears in Tieck's Volksmärchen but Nyerup has made this tone familiar instead of simple, and instead of being solemn it has a trite holiday-attire (helgdagsplatt). But, nevertheless, we owe Adlerbeth a large, yes, an almost enormous debt of gratitude for his enterprise which will certainly be worth while. All those who have been here (in Kongslena) have read it (Adlerbeth's Edda), all with a kind of astonishment, almost doubt, that anything of that kind could ever be written. If anyone, equipped with spirit and power, should arrive at this time and preach the old Sveogothism, I am certain that many, particularly of the younger generation, would take their position beneath the banner of power, against that dullness which has been so indefensibly preached by the Academic Journal (för Litteraturen och Teatern)." . . .

"The Lord is mighty! can be exclaimed with justification when one sees Iduna and learns [the name of] the author." . . .

" "The Viking' is a divine production, the first of its kind in Swedish. I am not so satisfied with the translations; Vegtams Kvitha, the only one I had the opportunity to compare with the original, is, I believe, slavishly faithful (to the text)."

"You ought to be all the more certain that I like "The Last Warrior" and "The Last Skald," since these strengthen my idea that Christianity has removed power and energy from Sweden."2

1 Letter to Hammarskjöld. Frunck: "Bref," V, p. 335.

2 For all quotations above, see ibid., pp. 336-37. In answer to this last 
This outburst of youthful enthusiasm needs no discussion; it cannot be taken very seriously, but it does serve as a striking illustration of a mixture of radical Gothism and Rousseauism.

In I8I I Livijn has another plan for a Norse drama. He writes to Hammarskjöld, April 2:

"What do you think about me? I intend to compete with Polyhistrio, ${ }^{1}$ and also produce an 'Odin.' The undertaking will, to be sure, be rather difficult, but if I am successful it will procure for me a double honor and decide the victory for us."

Hammarskjöld doubted the intrinsic unity of the subject ${ }^{3}$ and Livijn writes again, April 22, I8I I :

"You do not believe that I can possibly obtain unity in 'Odin'; I have almost the same opinion, but even if I am to drive my heroes together from Egypt, as Leopold (has done), they must come together. ... The contrast between the proud and arrogant but civilized Roman and the proud and arrogant but uncivilized barbarian will be the fundamental theme."4

As was often the case, Livijn's creative interest in Old Norse literature hardly went beyond the mere plan. It is a little difficult to decide just how much he actually accomplished in this line; some of his work was destroyed, what he did not destroy was mostly fragmentary, and very little of what survived was ever published. We have seen from his letters, however, that his early creative interest in the saga always suggested some dramatic scheme to his mind. It is quite certain, then, that beyond his ingenious attack on Gothic extravaganzas later,

contention of Livijn, Hammarskjöld writes: "If 'The Last Warrior' and 'The Last Skald' have strengthened your conviction that Christianity has injured our nation, then these poems must have produced an entirely different effect from the one intended by the author. . . . And besides, how much Christianity is there not in Icelandic mythology?" See letter to Livijn, September 12, I8I1. Frunck: “Bref," V, p. 353. Hammarskjöld agrees, then, with Atterbom that the spirit of Christianity existed in its embryonic state in Norse mythology.

1 The Fosforists' nickname for the Academician Gustaf af Leopold. See Appendix. He had written a drama on Odin in the French style. See Introduction, pp. 23-24.

2 Frunck: "Bref," IV, p. 268.

3 Cf. above, p. 67 , note 3 .

4 Frunck: "Bref," IV, pp. 283-84. 
Livijn's Norse plans revolved around, and were limited to, the drama "Gyritha" (I803), the opera "Balder" (I806), "Odin" (I8II), and the trilogy "Visbur" (I8I3). And we must notice in passing that the date of the first two is, in either case, several years before the Goths appeared, as such. Fortunately for us, the dramatic work of Livijn has lately been investigated by Mortensen, ${ }^{1}$ who has published the rough drafts of Livijn's Norse dramas that still exist among his papers. From these scanty remnants we can now obtain some idea of what Livijn intended to do in this field. I shall limit myself here to a very brief comment; for the details I refer to Mortensen's monograph.

Nothing has been found of either "Balder's Death" or "Odin." In all probability they never existed beyond the mere titles. ${ }^{2}$ But we do possess two small fragments of "Gyritha" and "Visbur." The theme of the former, the first of Livijn's dramatic attempts, is based on the saga found in Saxo, part I, book 7. Halfdan, Prince of Scania, has fallen in love with the proud and amazon-like princess Gyritha, the last of her race. He must win her by fame and bravery in war and for this purpose sets out for Russia, where he fights against the Swedish King Alver. A report is circulated that Halfdan is dead, and after many vicissitudes a Saxon, Sivard, is successful in winning the hand of Gyritha. Halfdan is notified, arrives just as the wedding is to be celebrated, kills the bridegroom and most of the guests, and obtains Gyritha. Livijn takes this story, adds in the French style a confidante, Afhilda, and a malicious rival and she-devil, Ulfhilda, both of whom are taken from a novel ${ }^{3}$ by the Dane Suhm, which is based on the same saga, and makes a plan for a three-act drama. The unity of action is strictly observed, the unity of time is indefinite, and that of place ignored. The fragment, a trifle more than five scenes of the first act, is written in rather commonplace prose, without dignity or eleva-

1 Mortensen: Clas Livijns dramatiska författarskap. Stockholm, I9II.

2 Cf. ibid., p. II9. Cf. also, p. 193. Mortensen suggests here the possibility that in case of "Odin," Livijn intended to write a regular drama à la Leopold to be a parody of the same.

3 "Gyrithe eller Danmarks Befrielse, Prisen For Kierlighed," I 774. 
tion, but has occasionally a certain power and interest. Ulfhilda is by far the strongest character in the fragment; she is a cunning intriguer, who, in strong, masculine language with feminine ingenuity, and under the pretense of patriotism, plans the abduction of Gyritha by Sivard to further her own loveinterests. She is a modern heroine as Livijn would have her. We have here the beginning of a drama, half French, half Romantic-historical. We can only regret that it was never completed, for it would have served as an excellent transitiontype. ${ }^{1}$

In I8I3 Livijn entertained a gigantic plan to write an opera in the form of a trilogy on Visbur. Snorre Sturleson's Ynglinga Saga (Chapters 16-18) tells the tragic tale of Vaulande, Visbur, and Domalde, grandfather, father and son, respectively. The old fate-idea, based on crime, hovers over the whole brief narrative by Snorre, though the main interest undoubtedly centers about Visbur. Vaulande has forsaken his wife Drifva and is finally strangled by a nightmare; Domalde was in time of famine sacrificed to the gods; and upon Visbur who, after desertion and remarriage, refuses to give up his former wife's bridal gift, the curse of his race had been placed. A part of the bridal gift, a neck-ring, was to be the death of the best of his kin, and racial murder should always prevail in the family. Using this saga and a Chronicon Finlandiae, Livijn made a brief outline in prose of "Visbur." It was to have three acts and was to be full of conjurations and witchcraft. It was to end in a general slaughter and suicide and Odin himself was to appear in the last act as a ghost; which gives Mortensen a good reason for believing that the plan of "Visbur" was modeled after Fouqué's trilogy "Der Held des Nordens."2 But our author never got beyond the fragmentary plan; the scheme was too colossal and, as Mortensen adds, ${ }^{3}$ it was left for Richard Wagner to write a trilogy on a primitive Germanic theme.

1 Mortensen : Clas Livijns dramatiska författarskap, p. 75. For detailed account of whole plan, fragment, and Suhm's influence, see pp. 62-75.

2 "Sigurd der Schlangentödter," Berlin, I 808: "Sigurds Rache"; "Aslauga," Berlin, i81o. Cf. Mortensen, as above, pp. 244-45.

3 Mortensen: Op. cit., p. 243. 
However ardent Livijn's love for the saga element was, he objected most strenuously to the abuse of it. When the "old Norse power" and Norse mythology became the objects of an empty, rhetorical idolatry, Livijn decided to give a signal of warning. The method of warning was similar to the attack made later upon Norse myths by the Academician Stjernstolpe ;" the Norse divinities of both sexes pay a visit to Mt. Olympus where they frighten everybody almost to death and put the Olympians to flight. But Livijn's ingenious ridiculing of the Gotho-mania was done in a friendly spirit and with the serious intention of bettering conditions, as is shown by his sober reflections on the Norse cult at the end of his article. The warning, in the prose-form of a dream, appeared in No. 3 of the short lived Life and Death (Lifvet och Döden), 1816, and is really a thrust at both mythologies. He finds the Olympians a rather triste company. "The old man Jupiter (Jofur) was recognized at once; he had seen him hoisted up and down on the opera, with flashing thunder-bolts in his hands. Minerva is studying economy and finance, Apollo stood with his hands in his pocket and pondered on the possibility of winning a prize on the 2oth of December, ${ }^{2}$ and the arrows of Cupid seemed so dull that they could be used only to pluck the strings of the lyre, etc. The whole company reminded one of yawning guests at some state-feast."3 But the Scandinavians arrive with a frightful noise and start a grand fight with the Olympians. Thor howls like all the wolves of the North put together, and when Brage sings, Apollo puts his fingers in his ears and flees. The rest follow. The new gods are to be lords of all Swedish poets hereafter, and to possess the sole right to appear in opera, ode, or elegy.

It is noteworthy that Livijn's ideas concerning the employment of Norse myths were fundamentally the same as those of Geijer concerning their use in the plastic arts. ${ }^{4}$ He implies that we must have sensuous form and definiteness in some way,

1 Cf. below, Chap. III, pp. I 5 ff.

2 The classical Swedish Academy awarded its prizes on this date.

3 Mila Hallman: Clas Livijn, p. 87.

4 See "Betraktelser $i$ afseende på de nordiska myternas användande i skön konst," I8I7. Cf. below, Chap. III, pp. I20ff. 
and we, who live in a new age when the gods in question are no longer worshipped, may employ the names from Norse myths only as poetical terms to give our ideas a certain sensuous definiteness. Nowadays the use of such terms, however, is often nothing more than a mere substitution of Norse names for Greek, and an affected pedantry is the result. On the other hand, if the scene of action is localized in that remote period when popular faith embraced Odin and Thor, and the atmosphere and costume are generally Norse, the names of the Old Norse gods are the most suitable. ${ }^{1}$ This is, in brief, the content of the serious part of Livijn's attack. It agrees, it seems to me, with Geijer's ideas: to obviate all danger, do not separate the Norse myths from their own age, and if you do, beware of excess.

The climax of Livijn's ridicule appeared in No. I9 of the above-mentioned Life and Death. It was a cruel parody on a solemn poem by Ling, entitled "In Memory of the Countess Hedvig Cronstedt" (Minne af grefvinnan H. C.), into which Ling had introduced the greater part of Norse mythology. Livijn calls his poem "In Memory of the Unwieldy Norse Power" (Minne af den obäkliga nordiska kraften), writes it in the same meter as his model, provides it with explanatory notes as Ling had done, and like Ling wants his poem set to music, and especially the explanatory notes. Ling's elegy adapted itself unusually well to irony and Livijn's parody is a masterpiece of its kind. The parody itself has true wit and the notes are excruciatingly funny. It caused bad blood, however, and the author felt constrained to make the explanation which appeared in the last number of Life and Death, in May, I8I6. For further details and examples in parallel columns of both model and parody I refer to Wirsén and Hallman, ${ }^{2}$ both of whom characterize the parody as "cruel." Incidentally, the character of the parody shows that Livijn must have been pretty well acquainted with Norse mythology in order to write it.

1 Cf. Wirsén: Clas Livijn, pp. 38-39. Contains quotations.

2 Cf. Wirsén: Op. cit., pp. 39-41. Cf. Mila Hallman: Clas Livijn, pp. 88-9r. 
It appears, then, that Atterbom was the only Fosforist ever to finish an imaginative work based directly on Norse mythology. Hammarskjöld objected to its use unless it was remodeled like "Skaldarmal" ; and Livijn's dramatic work, based on individual Norse sagas, was fragmentary. Yet we must not underestimate the importance of the zeal with which the Forforists, almost to a man, sought to encourage the study of Old Norse literature. This is the irrefutable testimony of letters written by the various members of the new movement. The correspondence of the minor members of the group brings out the same widespread sympathy and enthusiasm as that of the more prominent members.

C. A. Agardh (I785-1859), adjunct professor of botany and economics at Lund University and a warm associate of the New School, vents his feelings to Hammarskjöld, November 2, I8Io. He has read three numbers of Fosforos and objects to the superabundance of Hellenism in them. But he discovers one strophe in the Prolog which is particularly beautiful. He writes: "How beautiful, on the other hand, is Atterbom when he uses Gothic images, when he speaks of Thor; it is easier for us to believe that Thor still illumines his sons than that Phoebus should do so!"1 That Agardh took an interest in Ling's work is evidenced in the same letter, and later he takes issue with Hammarskjöld with respect to the employment of Norse myths in poetry. Agardh believes that Hammarskjöld's objections to their use may all be refuted, though it was not his (Agardh's) business to refute them. He adds: "Ling and Tegnér are agreed on the excellence of the Gothic myth."' That Agardh kept in touch with Danish literature of the Old Norse style is seen in a letter to Hammarskjöld of February 2, I8II. He is to send his friend some of Oehlenschläger's works as well as "Norse Mythology" by Grundtvig. But it is curious to note that Agardh also objects to an exaggeration of the new tendency. He writes: "He

1 Frunck: "Bref," III, p. I64. Cf. Prolog to Fosforos. Also note 4, page 32 of this chapter.

2 Frunck: "Bref," III, p. 175. Letter to Hammarskjöld of December 6, 1810. 
(Oehlenschläger) has published a new volume of his poetry, which does not seem to me to possess the value of the others. $\mathrm{He}$ has fallen too much into the old tone of the North. $\mathrm{He}$ has even imitated its faults."1

Those members of the new movement who were neither Goths nor Fosforists, technically, but who made use of the sagas and Norse mythology for the purpose of poking fun at the extravagances of the New School (see Chap. III) should be mentioned here. The most important of these were Vitalis (Erik Sjöberg) and Carl Fredrik Dahlgren. The character of their humorous products themselves shows that they knew something about Norse antiquity, and a study of their lives and works reveals a Gothic activity of a positive character as well. But this activity seems, for the most part, to be of a purely general type. Especially is this the case of Vitalis. His Gothic poems, if they may be called such, are patriotic and national, but are not based on any definite saga-sources. They deal with king and fatherland, with Swedish iron and mountains, and with occasional reflections on the primitive ages. "The Son of Nature" (Natursonen), as may be guessed from the title, is Gothic only in so far as it is Rousseauic. ${ }^{2}$

Dahlgren wrote several poems in a patriotic spirit, but his chief importance for Gothism was as an organizer. It was he who really founded the "Antiquarian Society" (Sällskapet för forntida minnen) in Linköping in 1823 , and he did much active work subsequently. He made speeches and gave books to this body, whose object was to "quicken the feeling of national patriotism, pure morality, and hearty friendship."3 Of more specific value for Gothism was Dahlgren's connection with the Manhems-Förbund. His biographer, Arwidson, writes as follows: "In conjunction with C. J. L. Almquist, Dahlgren founded in $\mathrm{I}^{8} \mathrm{I} 5$ the so-called Manhems-Förbund. Its purpose was to arouse in growing youth an interest in our antiquities and love for our historical monuments; in a word, to make the edu-

1 "Frunck: "Bref," IV, pp. 227-28.

2 Cf. Östergren: Vitalis, p. 50. Östergren believes "Natursonen" to be an imitation in the Gothic genre.

3 See Arwidson: Introduction to Vol. I of Dahlgren's Samlade arbeten, Stockholm, 1847, p. xv. 
cation of the young as Swedish as possible, with the high examples of the forefathers as models for a new, powerful, and patriotic generation. Consequently, it was for the young what the Gothic society was for the old. Others may judge the possibility of attaining the desired end in this way; but, in any case, the effort was noble and magnanimous. At the meetings the young men read selections from our old sagas to one another, and lectures were held on the Norse myths and on praiseworthy deeds from our historical chronicles. ${ }^{1}$ On special occasions Dahlgren himself delighted the members of the Förbund with speeches, many of them sparkling with wit and the love of life."

1 Ibid., pp. xiii-xiv. 


\section{CHAPTER II}

\section{The Non-Romantic Interest in the Norse Saga}

“ Kärleken till skaldekonst i allmänhet, och fäderneslands-känsla isynnerhet, hafva kommit mig att skrifva i meter, och att begagna den hos oss för litet kända och värderade, högst interessanta nordiska mythologien."

Charlotta d'Albedyhll: Slutanmärkning to "Gefion."

There was no enthusiasm among the Academicians for Old Norse themes but, on the other hand, it would be an injustice to accuse them of a constant and furious hostility. The old myths had already been treated in the French style by some Gustavians, notably by the king himself, Gustavus III., and by Leopold; so that at the beginning of the national movement Norse mythology was by no means unknown, even to the members of the Old School. And so, in I8Io, when the field of Norse myths was being explored in Denmark, the Academic Journal för Litteraturen och Theatern not only tolerated such exploration but advocated a similar movement in Sweden. No. 193, for August 20, I810, contains an announcement of Nyerup's Edda and gives the story of Suttung's mead. The Danes, the reviewer thinks, should be given credit for their interest in Old Norse history and myth, and Norse mythology ought not to be as unknown to the Swedes as it is, since it has already been used by "several German and Danish poets." The excuse seems to be that one does not like to learn Icelandic. Again, the recension of the first number of Iduna in the same Journal (numbers 195-98, I8II) contains an expressive regret: "The love for our antiquities and our history has cooled considerably among us (in Sweden) if it has not entirely died out." Later on, to be sure, when militant Gothism was thought to be alarming, the Academic attitude changed; but in the beginning of the decade $1810-1820$ there was an appreciable sympathy for national material among the conservatives. 
The Swedish Academy itself was not opposed to literary creations with Old Norse content provided they measured up to the traditional standards of form and style. In I8I2 the Academy awarded its highest prize to Per Adolf Granberg (I770-I84I) for a so-called "lyrical tragedy in three acts" on an Old Norse subject, entitled "Jorund." And, in his presentation speech to the prize-winner, the director of the Academy displays an idealistic view of the viking and sees great possibilities in the theme at hand.

"It was from the skald that the warrior of antiquity expected his most permanent reward; with his eye fixed upon the harp of the bard, ${ }^{1}$ the Gothic champion raised his sword, and, if a glorious death snatched it from his armed hand, he knew that the memory of the exploit would live through the ages in the eulogy of song. You [Granberg] have, my lord, called forth a theme from the old chronicles of Sweden which has the possibility of exciting high impulses and public sacrifices."

This complimentary and highly commendable sentiment would have applied admirably to other themes from the sagas, and was prophetic of what actually took place later, when Norse themes were treated by other more Romantic authors; but in the specific case of "Jorund" the judgment of the Academy was much too favorable. The work evidently fulfilled certain formal requirements of the Academy, it possessed some really good verse, and exhibited an occasional glimpse of genius, and the author had been publicly honored by the Academy before. ${ }^{3}$ Moreover, the theme of "Jorund" was new to contemporary Academicians and was patriotic in its essence; and so as a bit of original poetry, it captured the highest reward.

"Jorund" is an interesting concoction and Atterbom calls it rightly "a peculiarly constituted arabesk."4 It is not a tragedy

1 Neither the director nor Granberg himself made any distinction between "skald" and "bard."

2 A free translation. See Svenska Akademiens handlingar ifrån år 1796. Sjette delen. Stockholm, 1817, p. 31r.

3 According to Nordisk Conversationslexikon, Granberg received no less than five prizes from the Academy. He was a very productive writer in several fields. He wrote historical works and his dramas "Svante Sture" and "Märta Lejonhufvud" were played forty-two times between I8I2-33.

4 Literära karakteristiker (Vol. 7 of Samlade skrifter), Örebro, 1870 , p. 105 . 
in the modern sense at all but a lyrical melodrama, interspersed with reports of deaths and the flowing of blood somewhere off the stage. It is a bardiet à la Klopstock, steeped in artificial sentimentality with little or no local color or action. The main dialog is written in good blank verse, but, unfortunately, there is very little of it and to his prefaced outline of the argument the author adds apologetically, as it were, that perhaps this meter is altogether too new. As a result, we have a great variety of meter, distributed in the form of rimed duos, trios, and choruses of either bards, maidens, or fighters, and even an invisible choir is heard. The whole is a combination of Sturleson, Shakespeare, and Granberg. Sturleson provides the name and certain historical characterizations, "Macbeth" a part of the plan and the idea of an oracle, and Granberg, after distorting the original saga almost beyond recognition, motivates the "tragedy" by fate. The French confidante is not wanting and we may say that the unities are observed. The scene is laid in, or in the vicinity of, Uppsala, the principal characters are few and the plot is simple. Granberg makes Hake, who is said to have ruled three years, reign but one day over Sweden,--for no other reason, apparently, than to accommodate the action to the unity of time. From the dramatic viewpoint the stage directions are the most meritorious part of the whole bardiet, and at times suggest a setting of real viking beauty and picturesqueness. Granberg is not blind to the contemporary ignorance of Norse mythology and saga and provides brief explanatory foot-notes to his tragedy.

The Ynglinga Saga by Snorre Sturleson (Chapters 25-28) contains the historical background of "Jorund." Hugleik was a rich and stingy king who reigned over Sweden (Svithiod) quietly instead of going out on viking expeditions. $\mathrm{He}$ was always surrounded by harp-players, fiddlers, and magicians. Hake, a mighty sea-king, with twelve champions, including Starkad the Old, set out for Sweden, killed the inactive Hugleik and his two sons, and became ruler of the country for a period of three years. In the meantime Jorund and Eric, sons of Yngve, had grown up and won renown and Hake had sent his own warriors away. Jorund and Eric made use of their 
opportunity ; they came to Sweden, were welcomed by the people, and set out for Uppsala to recapture the throne for the Yngve race. In the battle that follows Eric is slain and Jorund is at first forced to flee, but Hake has been mortally wounded in the fray; he is laid "almost dead, or dead," upon his ship, the burning boat is sent out to sea, and Jorund returns to become king of Sweden. Chapter 28 of the saga, which Granberg disregards entirely, tells us further that Jorund was finally hanged by King Gylög while on a plundering expedition to Denmark.

Granberg states in his preface that he followed the opinions of those also who applied Saxo's story to Sweden. But he cannot have taken very much from the Danish historian. There is no Jorund mentioned in Saxo Grammaticus. The two champions, Geigad and Svipdag, are mentioned, however, both in Saxo and in Sturleson (Ynglinga Saga, Chap. 25), and Starkad the Old, who is mentioned in Sturleson in the same chapter as being the greatest fighter at King Hake's court, appears in Saxo, Book 6, as a very redoubtable Danish warrior. Granberg makes Starkad a native of Sweden who had left the Swedish court because of dissatisfaction.

There were, in fact, many skalds and singing vikings, but the typical Northern king or pirate was hardly a "lyrical" character; he was a sturdy, unflinching man of action. And so, when Jorund is made the hero of a lyrical tragedy we may expect at once a radical modification of historical facts. This is precisely what takes place. The Jorund of Sturleson is not a tragic hero at all, unless we consider his inherent craving for murder and plunder tragic. But this characteristic was common to any wide-range viking. Jorund is simply an ordinary sea-rover and king, who finally had the sad, though not "tragic," misfortune of being caught in his misdeeds. From a viking's viewpoint Jorund never knew any tragic guilt and the danger in which he lived was, undoubtedly, just what he wanted. The production as a whole is very much weakened by the infusion of an artificially created sentiment into the characters. They are not living individuals and are given no opportunity for dramatic development. There is too much singing and not enough 
dialog, though what there is is good. Granberg makes Hugleik, Hake, and Jorund contemporaries in war; Starkad the Old has become both "bard" and foster-father of Jorund; Hugleik, instead of being slain, makes peace with Hake and has his eyes put out; Hugleik's daughter Hilda and her friend Yrsa, neither of whom is mentioned by Sturleson in this connection, ${ }^{1}$ furnish material for the conventional love-scenes; and Starkad, as Granberg's instrument of fate, directs the show.

An appropriate name for the dramatic poem, according to Granberg's plan, would be "The Unavoidable Triumph of Jorund." It has now become a love story with love of woman and love of fatherland, where the hero cannot help but capture both. In the first act, Jorund, disguised as Halvar, is living an inactive life at Hugleik's court, enjoying the love of the weakling's daughter. But Jorund, as the son of Yngve, is destined to rule over Sweden, and so Starkad, in the hero's inactivity, employs the sea-king Hake to dethrone Hugleik and arouse the hero to action. According to the oracle, the ruling king, as in "Macbeth," must fall when the woods of Roslagen approach Uppsala. Messengers arrive from Hake; he demands Hilda and half of the kingdom and, upon receipt of the message that the oracle is being fulfilled, Hugleik loses courage and shuts himself up in his castle. Jorund now rushes forth and wishes to lead the warriors against the enemy.

From this point on the whole panorama could have been brought to a rapid close. Had Jorund been allowed to drive away the intruders he would have been the logical candidate for the throne, Hilda would have shared it with him, and the audience would have been ready at once for the triumphal postlude. But no! Starkad has promised Hake to reign one day, -a pleasure which is well deserved, to be sure,-and so, for the time being, he prevents the execution of the very thing he set out to accomplish and the panorama is extended for two acts more.

1 Sturleson does give in Chapters 32-33 of the Ynglinga Saga the story of a foreign slave Yrsa who became queen in Sweden, but she was not the contemporary of Jorund. Sturleson does not mention any women at all in connection with the story of Jorund, but we are told (Chap. 29) that Jorund had a son Ane who became king after his father. 
In the second act Jorund and his sweetheart are led around alternately by Starkad, Hilda being disguised as a soldier. Hilda must not reveal her identity to anyone until permitted to do so by Starkad. When she refuses to join the victorious Hake he is told that she has fallen in battle, whereupon Hake takes Yrsa and commands her to assume the name of Hilda, so that the people may believe that he is united in marriage to the Ynglinga race. Invisible beings are conjured up to arouse Jorund's jealousy by representing a union of Hake and Hilda. The shades of his ancestors pass in review and remind him of his duty to his fatherland. Deeply moved and in despair Jorund makes the resolution to suffocate his love and disperse the foe.

The last act deals further with Jorund's victory over Hake, sung by the bards. As a test of his sense of honor, the hero is given, and rather cleverly, the choice between the throne and Hilda. Of course, as in a French tragedy, honor and patriotism must come first, ${ }^{1}$ but Jorund stands the trial and Hilda proves herself equal to the severe and dramatic test of love. Then honor and love are reconciled, her disguise is removed, Hake has retreated and as King of the North burns himself on a pyre of trophies upon his ship, and Jorund is now ready to receive the homage of the Swedish people.

Much could have been made of that dramatic meeting between Jorund and Hilda, III, 4, where the latter in soldier's garb is ready to die at the hand of her lover in order to be mourned by him, but all we have now is a brief and rather insipid quartettsong which, naturally, cannot begin to do justice to the situation. There are other scenes also with excellent dramatic possibilities, as, for instance, in II, 4, between Yrsa, Hake, and Starkad. But here, too, the dialog is too concentrated, events are told too abruptly, important decisions made too suddenly and without sufficient exposition of the inner struggles of the characters. The much desired dramatic concentration and viking

1 Cf. I, 4, Hilda to Jorund:

$\mathrm{Nej}$, Jorund, allt för äran våga

om dina pligter fordra det;

Din älskarinnas bild förgät,

och för ditt rykte glöm din låga. 
directness are carried to the extreme, and before we realize what is happening the action is over and someone begins to sing. Had Granberg called his poem a "bardiet," any adverse criticism of this sort would have been unwarranted, but as a "tragedy," without even a well defined tragic danger, it is, I think, vulnerable.

That the Fosforists had nothing good to say about Granberg's work, ${ }^{1}$ was due, in part, to the fact that he leaned toward the Old School. Atterbom calls "Jorund " "a formless mass," and advises the author not to write another verse. ${ }^{2}$ It is called a "tragedy," says Atterbom, because someone dies and called "lyrical" because a part is sung. ${ }^{3}$ The manliness of the original is gone, there is monotony of rime, ${ }^{4}$ and Atterbom asks whether the original fate of the hero would not seem more probable now after reading Granberg's description of him. But the rationalists did not have the same opinion-the Academy certainly did not-and as late as I823 Martina v. Schwerin could speak of that "glimpse of talent," which was found in "Jorund."

But something good may be said even of "Jorund." It has no well-developed local color, as we have seen, and the sprinkling of Norse mythology is little more than mere names, but, nevertheless, there is a tendency to depict viking scenes and characteristics. I have already made the observation that the Old Norse directness of speech is too well illustrated; fight, fire, fate, feast and song compose the fabric of the whole bardiet. The ancestors' fondness for riddles is illustrated in the first scene and the participation of women in battle and their utter disdain for danger and death are brought out in the first

1 Cf. above, Chap. I, pp. 44 and 63 , concerning views of Hammarskjöld and Atterbom.

2 Svensk Litteratur-Tidning for ${ }_{1} 8_{14}$ (Nos. 20-2I), columns 326-27.

3 Ibid., column 315 , and note.

\& Atterbom believes that "dygder" and "bygder" must rime "certainly a million times" in Granberg's poetry.

5 See letter to Tegnér of December 7, 1823. Esaias Tegnér's papper, p. 194. The occasion for the remark was the appearance of "The Death of Karl Knutsson" (Karl Knutssons död), a tragedy in three acts by Granberg which did not have "that glimpse of talent" displayed in "Jorund." 
scene of Act II. ${ }^{1}$ Of course we feel that there is no real danger that Granberg's women would either kill anybody else, or die themselves, but the traditional characteristic is at least indicated. To have one's body burned, as Hake does on his ship, was a common viking phenomenon, and the scene in I, 5 , represents a council-place in the open air with its primitive judge's seat.

We find many phrases in "Jorund" which, though unnatural, are meant to be strong and to express a high degree of emotion; and the language is, of course, always polished and correct. Some lines, if taken by themselves, are really powerful and contain proverbial wisdom. The chief in I, 6, says:

"Den starke fordrar; blott den svage hoppas."2

The following patriotic and idealistic quotation has both good content and form. Starkad as bard is singing to Hugleik:

"När fordom en Konung blef hyllad i Norden han svor att bli värdig det välde han fått, och...trogen sitt löfte...vid gränsen af jorden han satte en gräns för sin ryktbarhet blott.

Ej mjuk var hans bädd och ej kräslig var födan, ej flockar af gycklare fyllde hans gård. Hans nöje var fejden, och...vunnen af mödan... hans hvila de sårade kämparnes vård."’3

Granberg's "Jorund" is primarily non-Romantic. But, aside from the subject matter itself, there are other tracespossibly made unconsciously - of the new contemporary tendencies. Hilda $(I, 4)$ is tormented by "a dreadful presenti-

$1 \mathrm{Cf}$. An äga vi de spjut, som våra mödrar burit, bevisom dessa män, som namn af kämpar fått, att våra fäders dygd, hvars dyrkan de besvurit, i arf till deras döttrar gått.

2 The strong man demands; only the weakling hopes.

3 Formerly, when homage was paid to a king in the North, he vowed to be worthy of the power he had received, and, loyal to his vow, set the limits of the world only as the limits for his fame. His bed was not soft, his food was not dainty, and flocks of jugglers did not fill his court. His joy was fighting and, won by toil, his rest was to care for wounded warriors. 
ment" (en gruflig aning), as so many of the Romanticists themselves were. The scene in II, 6 , is a typical Romantic scene. We have "a wild region between high mountains" and the whole illumined by the omnipresent moon. Hilda, as a warrior, is wandering about alone, aimlessly, as it were, directed by an unseen power, and in the greatest emotion:

"Hvart irra mina fjät? Till dessa vilda fjäll af hvilken okänd makt de föras!

Allt är så ödsligt tyst! blott vilddjurs läten höras, besvarade af klippans häll."1

Then, too, the conjurations, the cloudiness, the thunder, the flames, the invisible choir, the night, and the procession upon passing clouds of ghosts of ancestral kings (in scenes 7 and 8 of Act II), produce the effect of a Romantic atmosphere. Even Hake in III, I, is tormented by "a secret anxiety" (en hemlig oro). He fears nothing, but, like a Romantic dreamer, he does not know what the trouble is and cannot enjoy life. His royal power is great but even the gods cannot satisfy his thirsting soul. He longs for an inexpressible something which is far away, he knows not where:

"Jag vunnit hvad mitt hjerta eftersträfvat;

men är jag nöjd? Ack nej, min vän!

Den sällhets dröm, som för min tanke sväfvat, för mig är lika fjärran än.”2

"Jorund" should be remembered for its historical importance, for three reasons: It was based on a saga, it was written by a rationalist, and appeared at the beginning of the Romantic period, when the Fosforists were conducting their attack upon the Academy and all its followers.

We now come to another poetic production which should be remembered for similar reasons. When Granberg was receiving official and ostentatious recognition for his work, the treat-

1 Whither do my foot-steps go? By what unseen power directed to these wild mountains? Everything is so desolately quiet! Only the cry of wild beasts re-echoing from the cliff.

2 I have won what my heart strove for; but am I satisfied? Oh, no, my friend! That dream of bliss which has hovered before my soul is still just as far away. 
ment of another theme from Norse saga literature was just being completed. It was an epic poem in hexameters, based on Sturleson's mythico-historical Gefion, by the aristocratic but unassuming Eleonora Charlotta d'Albedyhll, née Wrangel (I770-1835). She was a rather independent poetess and neutral-minded, as far as close affiliation with any definite school was concerned. She inclined more, however, toward conservative views and kept up a lively correspondence with the Academician editor Wallmark. In the concluding note to her poem she gives her motive for writing and publishing her epic:

"This little attempt, with claim to nothing except the forgiveness of the reader, was written between 1810 and 1812 and was intended merely as a pastime for a few friends and for my own special pleasure. My opinion has been that to the epic belonged, essentially, that meter (i. e. the classical hexameter) which I have chosen; but that may possibly be a mistake which I hope will be kindly pardoned. Finally, it is as a result of my friends' encouragement, and at their request, that $I$ have had this insignificant work printed. Love for poetry in general, and patriotism in particular, has induced me to write in meter, and to employ that interesting Norse mythology which is too little known and valued by us."

"Gefion, a Poem in Four Cantos," appeared finally in I8r4, and was dedicated in glowing terms to the elected crown prince of Sweden. The brief dedication contains at once some important thoughts which later are developed in the epic itself and shows unbounded enthusiasm for the foreign-born prince. $\mathrm{He}$ is the peace-maker who will save the Northern iron from an everlasting blood-bath, he is the patron of agriculture, a "great man, born and bred in the luxuriant territory of the South." Then the poetess, with an assumed air of modesty and an implied enthusiasm for the South, pronounces her Northern poem "as destitute of flowers as the territory which produced the authoress."

"Gefion" is based on a part of the fifth chapter of the Ynglinga Saga. When the emigrating historical Odin had established himself, temporarily, in Germany, he dispatched the goddess of chastity, Gefion, northward to King Gylfe of Sweden, 
"who presented her with a piece of tillable land. She then went to Jotunheim (the home of the giants) and had four sons by a giant; these she gave the form of oxen, hitched them to a plow, and dragged the land out into the sea and westwards towards Odinsö (Odin's isle, Fyen,) to a place which is now called Seeland; there she lived afterwards. She married Skjöld, the son of Odin; they lived in Lider (Leire). Where the plowed land lay, there is left water or sea which is called Lagen (Icl. lögr, the sea, now called Lake Mälar). The fjords in the Lagen correspond to the capes on Seeland."

In the epic this mythical-historical tale is greatly altered. The historical element, as such, disappears entirely and the whole is made purely mythical and allegorical. ${ }^{1}$ Gefion has become a modern Ceres, as Atterbom has observed, and she comes directly from the home of the gods (Godheim) to the wild inhabitants of the North. She is now Odin's daughter and sister of Skjöld; appears in divine splendor in all Scandinavian countries, in Norway, Sweden, and Denmark, in the order named; and has only three sons, Nore, Sverker, and Dan, symbolic of the three Scandinavian lands. She finally ascends to heaven in the presence of the settlers of Seeland at a place which later became Leijre, then Copenhagen, the seat of the Danish kings. Fru d'Albedyhll makes an historical assumption, also, the veracity of which is at least questionable. Gefion teaches a Norwegian, Thuler, the use of fire, and teaches Gylfe the art of plowing. This assumption would give Sweden a priority in agriculture which is wholly unwarranted.

The first canto of the epic deals with deliberations of the Norse gods in Asgård on the future welfare of Scandinavia. The problem is how to improve conditions in the "icy North" by teaching its inhabitants the better use of their fields and minerals. Gefion is sent down to earth to carry out this mission. In the second canto, the bow-man Thuler ascends the Dofre mountain in Norway, on the summit of which he intends to pray for food and strength. Gefion appears in a cloud and joins him, they descend the mountain together, and, at the foot

1 Cf. the account of Atterbom's recension of "Gefion" above, in Chap. I, pp. 44ff. For the recension itself see "Literära karakteristiker," Örebro, 1870 , pp. I1 $5-35$. 
of the same, the trembling youth entertains his divine guest as best he can. Thereupon she calls forth fire from the earth, extracts iron from a stone near by, and teaches Thuler how to form it and use it. In "heavenly ecstacy" he embraces the goddess; Thuler's hut becomes a temple, and in the vision that follows he sees "three divine children," is told that the place upon which they stand is to be the future capital of Norway, and then the goddess disappears. In the third canto, Gefion comes to Gylfe in Sweden, where "the warriors lived on fish and game but lacked bread." The "majestic mermaid," with her "three small elves," arrives by water, and the arts of plowing, sowing, reaping, grinding, baking, and brewing are taught. Gefion spurns divinely Gylfe's offer of marriage, calls the land upon which she stands hers, changes her sons into oxen, and has the land pulled away. The poetess says: "Lake Lögaren (Mälar) still yearns for the hour when it may be re-united to the island." The last canto treats first of the deposition of the piece of land in the sea, then of the settling of this new island, and, lastly, of the ascension of Gefion to Asgård in the presence of the settlers.

A closer examination of the basic material in the epic discloses a very generous employment of Norse mythology in general. "Gefion" illustrates exceedingly well how deeply the Gothic tendency had become rooted outside Gothic circles, for, if we are to believe the statement of the authoress, the epic was begun before the Gothic Society was founded. Granberg's "Jorund" did not call for a very elaborate knowledge of Norse myths; it was based simply on an episode in an heroic saga and, judging from his tragedy, there is no evidence that Granberg went very deeply into the study of Norse antiquity. But with "Gefion" it is different. The whole framework shows a long step forward and reveals a tolerably complete knowledge of the Old Norse literature that was available in Sweden in I8IoI8I4. Both the Eddas and the Heimskringla are well known to the authoress, and we see in the appended notes that she knew what was being done in Denmark also in this line. ${ }^{1}$ In the first canto especially all the important Norse divinities are

1 Reference is made, for instance, to Baggesen's "Poesiens oprindelse." 
introduced as well as some minor ones, their characteristics and dwelling-places indicated, and their environment and physical attributes described. This is done in part by brief and accurate explanatory notes at the end of the epic, and in part by expressions woven into the epic. References are made to episodes in the lives of the Scandinavian gods, such as Vola's prophecy of Balder's death, and the final fulfilment of it at the instigation of Loke. A reference to the favorite story of the origin of poetry, the story of Suttung's mead, as told in the Tales of Brage (Bragarœður I) finds a place in the first canto of "Gefion."

The whole epic of "Gefion," comprising forty pages, is a mixture of modernity, classicism, and a sublime, almost Christianized, heathenism. The home of the Asa-gods and their high-sounding deliberations would do honor to any divinities. They are idealized; they move on a high, etherial plane, and are either stripped entirely of all intrinsic crudeness, or their crudeness is artistically concealed. The human and objective gods are made more subjective, divine, and majestic, and Gefion ascends to heaven much as Christ did. The classical hexameter lends a certain questionable dignity to the poem, but there is hardly enough of it in this case to make it monotonous. There are many references to local political conditions; in fact, "Gefion" is a vehicle for the glorification of the royal house and the ancestry of the authoress. ${ }^{1}$ Furthermore, it is a vehicle for the exposition of Northern nature. Though the narrative itself is necessarily brief and concentrated, the descriptions, whether of nature or of characters, are comprehensive and highly colored. Fru d'Albedyhll has a well-developed sense of the picturesque. The Scandinavian flora, fish, fowl, minerals, and climate receive constant attention with a goodly coloring of azure, purple, silver, and gold. If we add to the above that the epic has a prophetic and a didactic element, and shows influence of the spirit of Rousseau and Montesquieu, we obtain some idea of the poetic conglomerate "Gefion."

The comparatively new idea that the history of a people must be studied in the light of its geographical environment is strik-

1 Cf. above, p. 63, for Hammarskjöld's criticism of "Gefion." 
ingly illustrated in the fourth canto, 11. 60-65. Here the authoress touches briefly upon the topography and boundaries of the Scandinavian countries and indicates clearly their effect upon the character and political condition of the people. Denmark, for instance, is a level, fertile land; hence its inhabitants prefer "peaceful trades" and safety. But "the mountains of Norway and Sweden, on the other hand, have for a long time produced vikings. The temperament of a people is like that of the lands: one is protected by forests; the Baltic Sea (Eridanus) itself makes secure the freedom of the other."

Charlotta d'Albedyhll's conception of the viking age is characteristically Gothic. She implies that the modern era is corrupt by stating that the mythological age was incorrupt. It is the same Rousseauish spirit that permeated the minds of all the genuine Goths. The viking, to the authoress, was a godfearing, reliable citizen, whose faith, though pagan, had not been shattered by rationalism. The present era is a "soulless clockwork," wisdom has vanished, and nature is dead. The sentiments of the poetess are lucidly expressed in the first canto

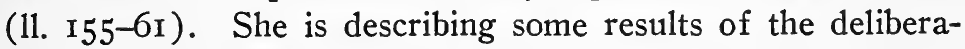
tions of the gods and this gives her occasion for a brief reflection:

Så rättvisan är stor och vördad i gudarnes samfund:

Så höll Göthen sitt ord i de oförderfvade tider,

Då Allfader ännu han trodde, och skydde ett Narstrond;

Innan klyftiga vislingar, med nymodiga påfund, Bortförklarat det herrliga Allt till ett Intet, ett själlöst

Urverk, dödat naturens lif, och visheten biltog

Flytt från en jord, der låga begär med dess namn sig besmycka. ${ }^{1}$

We have stated that "Gefion" was allegorical. The three sons of the heavenly messenger Gefion represent the three Scandinavian countries. If we carry this symbolism a step

1 Thus justice is revered in the society of the gods: thus the Goth kept his word in those incorrupt times when he still believed in Allfather and feared Narstrond (flood of sulphur in Muspelheim); before shrewd wiselings, with new-fashioned fancies, explaining away the glorious All to a Nothing, to a soulless clockwork, killed the life of Nature, and caused wisdom to be exiled from an earth where low desires adorn themselves with its name. 
further, we detect beneath the surface of the mythological fabric the didactic and the prophetic element, and both are often closely intertwined. The didactic element consists now of general truths, as the authoress sees them, and now of special teachings, applicable to conditions in Scandinavia. For instance, Gefion says in the first canto (11. 199-200) :

"Obedience is the duty of woman on earth, in Asa-home also; the mildness of meekness is power, and patience the strength of weakness."

Now take a specific application. From the strictly Swedish viewpoint, the teaching of patriotism in "Gefion" appears to be cosmopolitan, paradoxical as that may seem. The poetess prefers to look at the whole North as a unity. It is not a narrow-minded patriotism for Sweden alone which is discernible through these hexameters; it is a broad-minded sympathy for all the Scandinavian countries. "Gefion" breathes an ardent hope for prosperity in Norway and Denmark as well as in Sweden, and its fundamental tone is a plea for love, unity, and peace throughout the North. Gefion was sent down to earth to bring "abundance, comfort, and industry" to the whole North. "May my song," says the poetess (canto I, 11. II-I2), "please the three-fold North, when I proclaim the three-fold power of Gefion in the poem." It is tolerably certain that the authoress has some form of a political union of the Scandinavian countries in mind, when she speaks in canto 4 of the three crowns in the coat-of-arms upon the "Northern shield."

The prophetic element in "Gefion" may be said to have three parts : pure invention for the glorification of the Swedish nobility; the foretelling of events which the poetess already at the time of writing knew to be historical facts, and the hopeful penetration into the future, i. e., after I8I4. To illustrate the last two: iron is to become the treasure of the North, but the North does not realize its inestimable value; a prophecy, the fulfilment of which, during the last century, has proved of far greater consequence than the authoress could ever have imagined. But mark the didacticism again. This iron, "presented by Frigga to that righteous people who lived in woods and 
upon the mountains," may not be discolored by human blood, lest rust corrode it. Well did Charlotta d'Albedyhll know that during the last centuries Scandinavian iron had often been stained by human blood. But, on the other hand, if we look ahead with the poetess upon the nineteenth century we see with satisfaction that her wish has been realized; for there has been no war in Sweden since "Gefion" was published, now just a century ago. We may well say that the original mission of Gefion, as described by Charlotta d'Albedyhll in 11. I9I-96 of the first canto, has been satisfactorily fulfilled:

"Thules frusnade jord skall plöjas af idoga händer, Fruktbara fält från höjderna ses och mognade skördar: Jernet, Nordens klenod, ej alltid skall färgas af blodet, Rosten i fåran det skall afslipa, och glänsa likt silfver; Norden skall växa i makt, och trenne kronor den pryda: Detta blifver ditt verk, o Gefion vänast bland döttrar!"1

A word more about the descriptive coloring, and the frequency with which it occurs. At times the descriptive words have an almost Romantic tinge. In the very first canto (1. 36) Freya flees to her team from her "rosy bed" (rosenbädd), even Frigga's sandals are gold (1. 56), her voice rings out like a "silver-tone" (silfverton, 1. 65), and Gefion disappears like a "cloud of purple" (purpursky, 1. 216). In the following canto the sky is a "beaming purple" (strålande purpur, 1. 74), and the children of Gefion cling to their mother's skirt "with rounded hands of a lily-color" (rundade händer af liljfärg, 1. I78). Again, in the third canto, the horizon is "striped with gold, azure and purple" (1. 50), the sons of Gefion are here "gold-beaming alike" (gullglänsande lika, 1. 72), Gefion sweetens the brew for Gylfe with "honey-fragrant flowers" (honungsdoftande blommor, 1. I26), and then the half intoxicated king looks upon the "blue-eyed goddess with a delirious yearning" (yrande trånad, 1. I32). Forsete's palace

1 The frozen earth of Thule (the North) shall be plowed by industrious hands. Fertile fields and ripe harvests are seen from the heights. Iron, the treasure of the North, shall not always be stained by blood; it shall scour off the rust in the furrow and it shall shine like silver. The North shall grow in power, and three crowns adorn it. Let this be your mission, Oh, Gefion, fairest of daughters! 
in the last canto is, of course, gold and silver. Gefion's brother Skjöld has a purple cloak (1.23), from the shoulders of Gefion's children there appear "gold-gleaming wings" (gullskimrande vingar, 1. I36), upon the sky there flashes up a northern light, "blushing as the rose" (rosenrodnande, 1. I 7 I), and, finally (1. I87), we find a "silver-winged" (silfvervingad) shield. As an example of a rich coloring with a Fosforistic phraseology, the following description of Freya is worth quoting:

Freya, bekransad och skön, från sin slända leende uppstod:

Bar i hvar hand en svällande ros; en hvit i den högra,

Och in den vensta en röd; på bröstet glimmade Brising,

Höjande halsens bländande snö och rundningens svanglans;

Kring gullsnörade fötterna lätt flög luftiga drägten. ${ }^{1}$

The beautiful and detailed descriptions of Norse nature in "Gefion" constitute a very significant part of the epic. How true and realistic these are, and how disproportionately long in comparison with the total length of the poem, is seen in the following characteristic selection. It is a picture of the icy Dofre mountain in Norway, with its fowl and flora, and is inserted at the beginning of the second canto (II, I9-36) :

Dofres väldiga fjäll, betäckt af snö och kristaller, Hvilka till massor höjts af vinterns långsamma stränghet,

Började småningom re'n beskinas af värmande strålar.

Väl, i gestalt af ett vattenfall, som i forssandet stelnat,

Häftades isen ännu, bergfast, vid den hotande klippan;

Men för solens eldiga blick gaf vika hans hårdhet.

Droppvis göt han sig ned, förvandlad och tinad, till fjällets

Vidt omgränsande fot, i djupet, och ökade bäcken,

Som med möda sökte sig väg bland barren och skråf-is,

Senaste höstens gulnade löf och splittrade grenar.

Granens spetsiga topp sköt fram små fjällade förskott,

Björkens hängande ris betyngdes af knoppar med brunröd

1 Freya, crowned with a wreath and beautiful, arose from her distaff; carried in each hand a swelling rose; a white one in the right, and a red one in the left; upon her breast glimmered Brising (her neck-lace), heightening (the beauty of) the blinding snow of her neck and the swan-splendor of her bosom; around gold-laced feet flew lightly the airy garb. Canto I, 11. $8 \mathrm{I}-84$. 
Färg, och förnadens nedarsta del man skådade grönska, Då dess yttersta spets hoprullad hängde och torkad.

Af och an for gladan, och sträcker sin fläckiga vinge, Orren spelande yfs och tjädern slår tungt ner på granen, Breder en örnlik vinge så stolt, och hackar med näbben, Ruskar hufvedet se'n, och slår flerfaldiga flocken. ${ }^{1}$

In so far as "Gefion" preserves the original saga material we may call it Romantic. Then, too, the love for brilliant coloring and an occasional turn of phrase reveals a certain sensitiveness to the new literary disturbances. But beyond this "Gefion" must be characterized, like "Jorund," as primarily non-Romantic. The choice of meter, the elevated tone, and the prevailing objectivity stamp the poem as a rationalistic product. The naive charm of the primitive saga is suppressed entirely. The goddess, who is so human in the original myth, becomes enraged in a very rational way when Gylfe tries to embrace her, and, in revenge, she takes the piece of land by violence instead of being presented with it as a token of love and admiration. In other words, the motivation of the main action has become extremely selfish. It is motivated by a shallow, impulsive anger-the justification of which is at least very doubtful ${ }^{2}$-instead of by kindness and the unselfish desire of reward.

1 The huge mountains of Dofre, covered with snow and crystals, which had been increased to masses by the persistent severity of the winter, began already, to be illumined gradually by warming sun-beams. To be sure, the ice, in the form of a waterfall which had solidified in the running, still clung tenaciously to the threatening cliff; but its hardness gave way to the fiery glance of the sun. Transformed and melted, it trickled down into the depths, drop by drop, to the far-extending foot (of the mountain), and swelled the brook which made its way with difficulty through the pine-needles and brittle ice, through the yellow leaves and splintered branches of the last autumn. The pointed top of the spruce pushed out scaly shoots, the hanging foliage of the white birch was made heavy by buds of a brownish-red color, and the lowest part of the twig began to show green, while its extreme point hung like a scroll and withered. The kite flies back and forth, and stretches its mottled wing; the black cock, playing, spreads his plumage; and the wood-grouse beats heavily down upon the spruce, spreads an eagle-like wing so proudly, pecks with his beak, shakes his head afterwards, and gives his characteristic, varied call.

2 Tegnér doubted very much whether a human goddess would be so terribly offended at the king's intended caresses. The principal moment of 
The authoress submitted her epic to Tegnér for criticism and his views are contained in a letter to her, dated July I5, I8I3. ${ }^{1}$ Tegnér omits purposely "what is beautiful in the poem" and devotes his attention to what he considers "less successful." He doubts the suitability of the hexameter for a Gothic theme; the hexameter should be limited to translations from, and imitations of, the antique, such as Voss' "Luise" and Goethe's "Hermann und Dorothea." The hexameter is, after all, out of harmony with Old Norse content; it is, in this case, a "Roman tunic on a Northern goddess." For the Gothic languages the sagas and older German poems, for example, the "Lied der Nibelungen," furnish suitable verse-forms. The critic has another objection. For Gefion to give instruction in the art of brewing (canto 3 ) is unnecessary and out of place, he believes; it is out of harmony with the tone of the rest of the poem. The plan of the whole, also, lacks that well-rounded development and completeness which is a paramount merit. For instance, it is unnatural to think that any barbarian like Thuler should be ignorant of the use of fire. Again, nothing new takes place on Seeland, for Gefion really teaches agriculture in both Sweden and Denmark. Tegnér proposes the following plan: the exposition of the gradual development of the State in the North out of a condition of barbarism. This would involve three important stages: the age of hunting and fishing, the age of stock-raising, and the age of agriculture. The scenes of these three stages could be laid in Norway, Sweden, and Denmark, respectively, and be depicted in three separate songs, much as the poetess had already done. The myth about the oxen would then be appropriate in the second canto. All this might not be absolutely correct, historically, but that would make little difference from a poetic viewpoint.

action thereby receives "an aspect of accidentality and chance," says Tegnér, "which can hardly be reconciled with the general laws of art. Because it seems to follow, that, if Gylfe had had a colder temperament and had been less intoxicated, Seeland would have been lying in Uppland (in Sweden) to this day." See letter to E. C. d'Abedyhll of July 5, 1813. In "Skrifter" Jubelfestupplaga, V, pp. 91-92. For whole letter see pp. 88-93.

1 See preceding note.

2 In "Gefion" the hexameter was not always perfect either and needed a thorough revision. Even in their final form some lines are difficult to read. 
What effect these suggestions had upon the mind of the authoress we cannot tell. But the fact is that the epic appeared in its original form, with some verses revised, perhaps, and the plan remained unaltered. And so we must accept the epic as it stands, and for what it is worth. It is an interesting bit of readable poetic experimentation, with Old Norse content and classical form. Most of the hexameters are good, nothing is felt as commonplace, many passages are really beautiful, and the time of composition and publication gives the poem a certain historical value. 
The Theoretical Problem of Introducing Norse Mythol- , ogy into Swedish Art and Poetry

“Der griechieschen Mythologie steht, wenigstens in romantischer Erhabenheit weit näher als die indische, die nordische, ein Reich voll Eispalläste, Eisseen, Eisberge; ihr Menschengeschlecht ein Eichenwald im Sturm."

Jean Paul Friedrich Richter: Review of Fouqué's

"Sigurd der Schlangentödter."

What would have happened if "Frithiof's Saga" had appeared at the beginning of the Romantic period in Sweden instead of toward the end? Would it have deflected all the new tendencies into the national channel and destroyed the symbolic, philosophical movement? Would it have silenced neutral skepticism and conservative opposition to the antiFrench system of literary expression? Nobody can tell with any degree of precision, but it is tolerably certain that, if a poet of Tegnér's caliber had treated some phase of Norse mythology at an earlier date, the objections to its use in art and poetry would have been much reduced, if not entirely eliminated. As it was, no one had been able to prove, in a practical, convincing way, that the indigenous sagas and myths had any real artistic value, and the mere fact that they were indigenous was not sufficient. The prejudice against anything new, whether national or not, was shamelessly strong and the burden of proof, naturally, lay with the reformers. Atterbom in his "Skaldarmal" could not expect any revolutionary success; as we have seen, it was a commendable and important poem, historically, but it was no phenomenal masterpiece and the author had already fallen into disrepute by his Fosforistic obscurantism and had a marked prejudice against him. His direct Norse influence on the Old School, therefore, could not be very effective. Geijer, whose national poems (on the viking, the 
primitive farmer, the last warrior, and the last skald) had appeared in the first number of Iduna, was eulogized by Fosforists, neutrals, and conservatives alike, but he never employed S'candinavian myths, per se, at all, as a basis for his poetry. Geijer was too objective and had too keen an historical sense, it seems, to venture very far into an unexplored mythological field. Ling was the only man who took up the subject comprehensively, but he went to the other extreme, so that even the Goth Geijer became alarmed, and the beginning of Ling's gigantic epic, "The Asas" (Asarne), of which eight songs appeared in 1816 , left the question of ultimate success a matter of conjecture.

It may, then, not seem so strange that, during the second decade especially, there continued to prevail a certain lukewarmness or skepticism about the adaptability of Norse mythology to poetic themes, even among some members of the New School. Natural disasters, such as the loss of Finland, were equally unable to create a general, unalloyed faith in national myths, and the problem of their suitableness for the plastic arts was a still more serious matter. The main results of this agitation were a series of lectures on Norse mythology and art by Ling, a treatise on the adaptability of the new myths to plastic art by Geijer, a parody and a satire on the Gothic tendencies in art by the disciples of the Old School, and some light, inoffensive satire by Vitalis.

Sweden was not the only country to sound, by theoretical means, the practicability of introducing Norse divinities into art. Both Germany and Denmark preceded Sweden in this respect. But wherever the problem is agitated the method of approach is the same, namely to compare the new mythology with other poetic systems, using Greek mythology as a standard.

Herder adopts this method and in his "Iduna, oder der Apfel der Verjüngung," he expresses in dialog form his own views on the subject. Norse mythology may not be adopted in art or poetry at the expense of the Greek, which is the most refined in the world, and, moreover, plastic art and a philosophy of art never thrived (war nie zu Hause) under a Northern sky. ${ }^{1}$

1 Sämmtliche Werke (Suphan edition), Vol. 18, p. 501. All references are to this edition. 
That all the Germans were not of the same opinion, however, is seen in Herder's second treatise on Norse mythology, " $\mathrm{Zu}$ tritt der nordischen Mythologie zur neueren Dichtkunst." After speaking of the work of Klopstock and Gerstenberg on Northern themes, he adds: "Soon there arose a party who not only placed this (Norse) mythology above the Greek, but in comparison with the former almost ridiculed the latter."1 In I807 Gräter publicly suggested the employment of Norse myths in art, but the continental wars temporarily frustrated his plans. His letters on the subject, however, appeared in Danish translation in Copenhagen in $1821 .^{2}$ From $1812-1816$, in Idunna und Hermode, Gräter proposed to furnish a series of copper engravings on characters and scenes in Norse mythology to serve as a guide for students in plastic art. ${ }^{3}$ Gräter received much encouragement in his proposals from other German and Danish authors.

In Denmark the a priori reasoning for and against the recognition of the Norse myths in art or poetry was unusually violent and raged for several years. There were two factions: one pleaded sensibly for an appropriate use of the national myth, and the other sought to disqualify it entirely. There was no attempt on the part of the radicals, however, as far as I know, to discredit the Greek mythology by ridicule, as Herder tells us was the case in Germany, or as Romanticists were forced to do in Sweden. The history of this controversy is well known, especially in Scandinavia, and I need only refer here to an important aspect and conclusion for the sake of its bearing on the controversy in Sweden.

In 1800 the University of Copenhagen submitted the following questions for consideration. "Would it be beneficial for the polite literature of the North if the ancient Northern mythology were introduced and accepted in place of the Greek?"4 Three young enthusiasts responded by written treatises, Oehlenschläger, J. Möller, and L. L. Platou, all of whom later became

1 Werke: 24, p. 312 . Cf. above, Chap. I, p. 15.

2 Cf. Hjärne: Götiska förbundet, p. 69.

3 Cf. Blanck: Den nordiska renässansen, p. 182.

4 Cf. Arentzen: Baggesen og Oehlenschläger, I, p. $197 \mathrm{ff}$. 
professors. Oehlenschläger, whose paper received an accessit from the university, found a wealth of epic material in the Norse myths and believed that the older the period from which the poet took his material the better it was for him. ${ }^{1}$ The Northern myths were neither unfruitful (fattig) nor coarse (raa) and all the competitors agreed that Scandinavian mythology might well be introduced into art, though not at the expense of the Greek or Roman. ${ }^{2}$ This view is substantially the same, then, as that of Herder. In the interim, the battle in Denmark was constantly growing in intensity. In I8r2 Möller published an article on the adaptability of the Norse myth to the fine arts. As an extreme type of the conservatives we may mention the Danish professor Thorkel Baden. Baden believed, as did the German Schlözer, ${ }^{3}$ that the Edda was nothing but an invention of Christian monks and not a collection of original, ancient poetry. ${ }^{4}$ Professor Baden doubted whether the Norse myths had ever been a living belief of a people or that they could be employed successfully in art.

Just as the Romanticists in Sweden sought to establish an independent, national poetry, they (and more especially the "Goths") sought also to pave the way for an original, national school of art, based on Norse mythology. It was a determined assault upon the old ramparts, even in this case, with no respect for lawor authority. But to the ultra-conservatives, who stripped the characters of the new myths of all human traits and ignored their position in the more historical saga, the resuscitated divinities became formless monsters. And then the exposed gods were submitted, from the beginning, to the same searching test as in other countries, that is, to a comparison with the idealized classical divinities. The fact that the new gods were Norse, as I have just said, was of little consequence to the skeptical mind; patriotism did not serve to render a lenient verdict and the old academic school of art insisted upon an exclusively classical raison d'être.

1 Cf. ibid., p. 199.

2 Cf. Hjärne : Götiska förbundet, p. 69.

3 Presumably August Ludwig v. Schlözer (1735-1809). He published "Allgemeine nordische Geschichte," Halle, 1772, 2Bde.

4 Cf. Hjärne: as above, p. 63 . Ling replies to this contention in his "Sinnebildslära." 
As early as I798 A. E. Afzelius expressed the conviction that Norse mythology was better suited for Swedish customs than the myths of Greece and Rome. ${ }^{1}$ But in I8II the Academic organ, Journal för Litteraturen och Theatern, edited by Wallmark, takes a different stand. In a review of the first number of Iduna, ${ }^{2}$ the reviewer laments, indeed, the frigid attitude toward "our ancient monuments and history," and on the whole, gives a favorable criticism of the new periodical, but reveals a slight preference for classical mythology. The Norse myths deserve to be known and used both from an historical and esthetic standpoint, but they cannot replace the Greek or Roman. ${ }^{3}$ We have, then, from the first, as in Denmark and Germany, two opposite tendencies, although, as we shall see, no important Swedish critic of art existed, whether Goth, neutral, or Academician, who ever expected or intended actually to replace the Greek system.

From I799 to I804 Per Henrik Ling studied in Copenhagen. $\mathrm{He}$ attended the private gymnastic institute of Franz Nachtigall, plunged into grammars and dictionaries at the Royal Library, and became acquainted with the works of Ewald, Baggesen, and the young Oehlenschläger. He learned to know the ancient Northern literature and culture, which began at once to have a tremendous effect on the future epic poet and teacher of gymnastics. From 1802 to 1804 Ling attended the lectures of Henrik Steffens, who sought to interpret the deep meaning of the golden, mythological age; an age when the universe itself was looked upon as a spiritual organism, "when sacred sagas interpreted the future history of the earth, and profound symbols (myths) reflected the metamorphoses of nature."4 It was an age of harmony, plastic art, and epic poetry. Ling returned to Sweden in 1804 , became teacher of fencing at Lund the following spring, and soon after that began to formulate plans for a wholesale introduction of Norse mythology and saga into Swedish poetry and art.

1 See above: Introduction, p. 24. Cf. also Blanck: Den nordiska rennässansen, p. 299.

2 Numbers $195-98$.

3 No. 198.

4 Cf. Westerblad: P. H. Ling, p. 17. Contents from Steffens: Inledning til philosophiske forelaesninger. Kjöb., 1803 . 
From a letter by Carl Adolf Agardh to Hammarskjöld, dated August 6 , 1810, ${ }^{1}$ we learn that the latter was engaged in writing a sort of history of Swedish art for Ling's benefit. Evidently Ling had already in mind something like his future lectures on the use of Scandinavian mythology in ant, and desired to obtain a characterization of the most important Swedish artists up to that time. Ling asked Agardh to thank Hammarskjöld "a thousand fold" and to write him not to trouble himself about the less important geniuses. In the spring of I8I4, however, Hammarskjöld himself made public use of his material and delivered fifteen lectures in Stockholm upon the history of art. They were repeated in the spring of the following year. They have no particular significance for us, for most of the lectures dealt with foreign artists, ${ }^{2}$ and only the last lecture was devoted to Swedish art. Yet Hammarskjöld should be remembered as a pioneer in this field, and as a Fosforist unknowingly helping a Goth of the most extreme type to prepare the way for new motifs and a national art. Hammarskjöld's lectures were published later and reviewed in Svensk Litteratur-Tidning, I8I8. ${ }^{3}$

No one was more ardent to introduce the new mythology than Ling, and from I8I4 to I8I7 he delivered in Stockholm, under the auspices of the newly organized "Society for the Study of Art," his meritorious lectures on the "Employment of Norse Myths in Fine Art." Ling had already tested, or was testing, the new saga element both in epic and dramatic form; he looked to Norse paganism for his ideal; the power, the depth,

1 Frunck: Bref rörande den nya skolans historia, II, p. I16.

2 Oriental, Greek, Roman, Italian, Flemish, German, Spanish, English, and Danish.

3 "De bildande konsternas historia," reviewed in numbers 8, 9, 12 and 13. Hammarskjöld is criticized here for haste and serious mistakes. Judging from the above mentioned letter by Agardh to Hammarskjöld, we must conclude that Hammarskjöld attempted to cover the field too minutely, found the task more difficult than he expected for the time he had at his disposal, and so failed to grasp all the fundamentals.

4 The lectures were first given in a hall at the Institute of Gymnastics and then, in 1816 , in the so-called "lilla Beursalen." Cf. Westerblad: Ling, p. $8 \mathrm{I}$, and note 3 .

5 The first draft of the epic "Gylfe" appeared in 1810, the tragedy "Agne" in 1812, the historical tragedy "Eylif den Göthiske," of early conception, 1814 . 
and the grandeur of the native mythology appealed to him with an irresistible force. In patriotic spirit and love for Swedish antiquity he was a Rudbeckian; in practice, a religiously devout student of all Norse mythology. The science of gymnastics gave him an insight into the harmony of the human body, and he now yearned to see his ideal type personified in art in terms of Odin, Thor, or Frigga. J. Adlerbeth writes to Tegnér from Stockholm, the IIth of April, $181_{5}:^{1}$ "From the end of January to Easter, Ling lectured here on Norse mythology to a very large audience," and Adlerbeth, who attended the lectures, characterizes them as being of "really great merit."

A complete record of Ling's original lectures has never been found, but a good general idea of their contents and value may be obtained from Ling's "Symbolism of the Eddas" (Eddornas sinnebildslära) published in $1819 .^{2}$ According to Ling himself $^{3}$ this work was to consist, ultimately, of four parts and the last was to contain a mythological dictionary and a supplement for the guidance of painters and sculptors. Only the first part ever appeared complete in print, however, and only detached parts of the supplement (Bihang) for artists. But the introduction to the first part and what remains of the supplement are sufficient for our purpose.

Ling uses the comparative method like Herder and Oehlenschläger. With some historical sense he shows how the geographical location and climate turned the Old Norse method of artistic expression into lyric form rather than into painting or sculpture, as was possible in Greece. Ling does not expect, any more than his predecessors, that the Northern myths will expel the Southern ; ${ }^{4}$ but they were from the beginning incor-

1 Esaias Tegnérs papper, p. 68.

2 Ling's theoretical views on Norse myths are scattered all through his works and often specifically stated in his elaborate notes to his Asa-epic. From these the contents of his lectures can easily be synthesized. We possess a few of Adlerbeth's notes on Ling's lectures, but, apparently, they cover only a period of about a week, from the thirteenth to the twentysecond of November, r8r6. Cf. Westerblad: Ling, p. 83, and note 2. The "Sinnebildslära" is favorably reviewed in Svensk Litteratur-Tidning for I 820 , Nos. $35-36$.

3 See Samlade arbeten, II, pp. 332-33. References are to this work.

4 Ibid., p. 330. 
porated with the skaldic tongue of his forefathers and should therefore be revived. Both Greek and Norse myths contain poetic creations which it would be difficult to represent faithfully in plastic art. ${ }^{1}$ The Odyssey and the Aeneid, as well as the sagas, contain monsters. Giants with dragons' tails, centaurs, satyrs, or cyclopes are as little adapted for the chisel as "our formless trolls." Our Norse ancestors never offended the law of beauty but no artist sought to perfect it. ${ }^{2}$ The Greek has a larger number of "beautiful symbols" from social life and sensual pleasure, but the Norse far outstrips the former in the number of those with moral and religious attributes. ${ }^{3}$ The Norse myth is serious, gloomy, and mysterious; that of the Greek mild and charming."

Ling's "Edda-Symbolism," as the name implies, bears an unmistakable Romantic stamp. He revels in the Norse myths like a child in a fairy-story. To grasp their full meaning one must reflect upon these myths with the fervency of a child. ${ }^{5}$ The language and spirit throughout is that of a Stürmer-undDränger who is determined to make his point. Flashes of genius, forceful expressions, and a wonderful acuteness in his arguments, give his plea a logical and convincing character. In many respects his method and patriotism remind one of Heinrich von Kleist. Kleist had no sympathy for the Rheinbund, whose members he considered traitors to the fatherland; similarly, the Asa-bard becomes almost fanatic in his assertions about his countrymen's indifference to national material. That citizen who is "cold to native traditions and doubts the possibility of restoring his country's honor, is already in danger of becoming a traitor to his fatherland." "The cosmopolitan is the most lukewarm and weakest of all beings." ${ }^{\prime \prime}$ It ought to be the duty of every mother not to make her offspring an "ape," that is an imitator of foreigners. ${ }^{8}$ The Norse myths are the beginning of Scandinavian history and the great personalities in its sagas represent the "Urbild" of the nation's power.
1 P. 325 .
5 P. 33 I.
2 P. 325 .
6 P. 330.
3 P. 327.
7 P. 329.
4 P. 322.
8 P. 330. 
More than that, the Norse myths contain the very fundamental germs (grundfrön) of a revealed religion and every one of its "pagan thinkers" felt (anade) the "eternal truths of Revelation." 1 Symbols-and Ling means those in the Edda especially -are the real language of religion, and the myths represent our ancestors' crude investigations in religion and philosophy. The Romantic art of poetry is a true, inherent element of the Norse myths. The Scandinavian gods and goddesses are nature-symbols ${ }^{2}$-observe the influence of the Romantic naturephilosophy-in no wise antagonistic to Christianity, and may therefore be employed with propriety by artists of Christian faith. Rousseauism also plays a part in Ling's interpretation of the Edda-myths. The myths of a people become "broadened, or more correctly speaking corrupted, the more the number of its poets and the political power of the people increase; for then this religious, philosophical art of poetry assumes a more historical character, and actual events expel, to a large degree, the meaning of the symbols which its thinkers and skalds have introduced." 3

The fragmentary supplement for artists, as printed, contains but 34 pages, ${ }^{4}$ including four on Old Norse dress and armor. It is a careful compilation of the mental and physical characteristics of the various Scandinavian divinities, with their important attributes, all based on the Edda. Naturally much attention is paid to facial expression as a mirror of character, dignity, and office. Many of Ling's suggestions are to be taken merely as suggestions; originality is of paramount significance in art and the details of the execution, therefore, are left to the discretion of the artist. ${ }^{5}$ As much as possible the artist should avoid all direct imitation of the Southerners, ${ }^{6}$ yet Ling himself borrows suggestions from Greek masters. ${ }^{7}$ He recognizes that

1 P. 33 I.

2 P. 326 .

3 Pp. 324-25.

4 Pp. $441-74$, inclusive.

5 Cf. p. 457 , suggestions relating to the goddess Sif. Also p. 450 , relating to Brage, and p. 459, to Freja.

6 P. 458.

7 Cf. p. 457 , where Ling suggests a definite style of hair for each of the goddesses, "as the former Greek masters had adopted for the Greek divinities." 
the problems confronting the painter and the sculptor are different; a fish-net as an attribute of Ran can easily be represented by the former but hardly by the latter. ${ }^{1}$ Ling admits than an eight-legged horse like Odin's Sleipner can "scarcely" be represented as standing by the side of Hermod. ${ }^{2}$ It must be admitted that Ling shows a decided preference for Norse mythology, even if he never intended to drive out other poetic systems. $^{3}$ Our Scandinavian ancestors, according to Ling, had a "positive" and "pure" feeling for the beautiful. Not in one single instance (i. e. as evidenced in the sources) did they forget the laws of beauty. "Their divinities are all represented according to the most perfect form, i. e., the human form; they have never, like the Egyptians, Hindus, Chinese, or even the Greeks in the beginning, represented their gods in the shape of multiplex beasts, with manifold arms, heads, eyes, etc.; and they have never even permitted themselves to represent the god of evil, Loke, in any more horrible manner than the other gods or goddesses." Only that which belonged exclusively to the lower world, such as the children of Loke, was represented as horrible, and its giants and trolls were made monstrous, because they belonged to "formless nature." The highest god or Allfather was never conceived by "our ancestors" in sensual form and, therefore, "cannot be represented by the artist in connection with the Eddaic nature-divinities. ${ }^{5}$

A couple of concrete examples from the supplement will illustrate Ling's suggestions for painters and sculptors. Brage, the god of mead and poetry, should be a " middle-aged man with long beard; for he is called 'the long-beard." "His face should express wisdom and feeling, but not bravery or courage. Let his mouth be ready to speak." He possessed a horse and a sword, but it is desirable that his sword (the symbol of satire)

1 P. $46 \mathrm{r}$.

2 P. 452.

3 Lydia Wahlström in "Den svenska odlingens stormän," V, p. 80, calls Ling's preference for Norse myths "tremendous" (ofantlig), and bases her claim on Ling's comparative estimates of the Greek and Norse myths, as viewed from an ethical and religious standpoint.

4 Ling: Samlade arbeten, II, pp. 443-44.

5 Cf. p. 446. 
be placed at his feet. In one hand he should hold the Bragecup and rest the other on his harp, "which should be larger than the one given Apollo, and not constructed in the same way." "From the sagas we know that these instruments were so large that even children could be concealed in them." This form, too, could hardly be suitable for Brage and the artist himself should select a suitable one. Brage should be draped, but without a helmet." "Nanna, the wife of Balder, ought to be represented as clothed. The left breast ought to be more exposed perhaps, and maybe her hand placed over it, provided this does not give her a super-theatrical aspect. The myth says: "her heart broke.' I presume that the artist ought to direct his attention to her as the goddess of tender affection (Ömhetens gudinna). Her face should be young, beautiful, but suffering; and her mouth as if smiling beneath her pain. About her waist she should have the girdle which was burned with her; and on her finger the golden ornament which she sent to Frigga from Hel."2

The lectures by Ling had an immediate and "particularly encouraging" result, the more so because the lecturer associated with several young artists, some of whom lived in the same house that sheltered his gymnastic institute. ${ }^{3}$ Of these Bengt Erland Fogelberg, the sculptor, was an actual pupil of Ling ${ }^{4}$ and was directly influenced by him. In the spring of 1817 an anonymous donor (now known to be the envoyé Baron G. U. Silfverhjelm), an attendant upon Ling's lectures, gave the sum of 50 ducats to the Gothic Society as prize for either a Swedish or Norwegian artist who should draw and develop some motif from Norse mythology, either in architecture, sculpture, design, or painting. This offer was discussed by the Society on the Ioth of June, I8I7, and competitors for this prize were advised by the Society to study the Eddas diligently, both the poetic and prose Eddas, as being " the richest and most reliable

1 Cf. p. $45^{\circ}$, for Brage.

2 P. 456.

3 Cf. Wahlström: Den svenska odlingens stormän, V,p. 83. Westerblad (Ling, p. 82) mentions Fogelberg, Sandberg, and Wahlbom who lived in the same house that sheltered the Institute.

4 Cf. Hjärne: Götiska förbundet, p. 55. 
source of information about the Norse myths." 1 Prespective competitors were recommended also to study Ling's "Gylfe" and "The Asas" ${ }^{2}$ for inspiration and ideas." Themes were suggested by the Society for various branches of art, viz.: for plastic art: the supreme Odin on his throne Lidskalf looking down upon the world and seeing all that takes place; or Thor riding in his chariot, fighting the giants. Someone suggested as a theme for architecture, Valhalla, the dwelling place of Odin and the heroes fallen in battle. As Ling had advocated in his supplement, the artists were allowed a great deal of freedom, for, above all, independence was desired. The announcement of this competition was printed in Inrikes Tidningar, June I8, I8I7, ${ }^{4}$ and several candidates responded, 5 among them Fogelberg. According to contemporary evidence, Hjalmar Mörner, who had just been reading Ling's poetry, was called upon to decorate the salon of one Rosendal, and chose to picture the entry of Odin and his Asas into Scandinavia. ${ }^{6}$ As late as 1850, when Bernh. von Beskow, himself a former student of painting, wrote his biography of Ling, artists, in response to a demand for competitive work from "Gothic" mythology, "probably," received more ideas from the poetry of the Asa-bard than from any other poet. Because no one portrayed "these antique images so

1 Ibid., pp. 55 ff.

2 In the edition of 1814 , the political allegory "Gylfe" in Norse dress contained fifteen songs. It will be remembered that eight songs of "The Asas" had appeared in 1816. Cf. above, p. 99 ; also note 2, p. 104.

3 Cf. Hjärne, Götiska förbundet, p. 149.

4 Printed in Hjärne: Götiska förbundet, pp. 146-49.

5 Cf. Wahlström: Ling, p. 83.

6 Berh. v. Beskow: Life of Ling in Vol. I of Ling's Samlade arbeten, dated in Stockholm, April 22, 1859. Cf. p. xxiv. Beskow on this page mentions the names of several artists who were influenced by Ling. Beskow was 21 years old in 1817 and was wide-awake to all contemporary affairs. Cf. note on Beskow in Appendix. Hj. Mörner was admitted into the Gothic Society February 16, 1829, and instead of "within three months" giving a speech on his Gothic namesake, as others were supposed to do, he submitted eleven sketches representing myths about Odin, and about the coming and settling of the Asas in Sweden. Cf. Hjärne: Götiska förbundet, p. 18. Nicander says of Hjalmar Mörner:

"Din samtid kunde ej Ditt snille kröna ...

Hvad gör det? Konstens mål du hunnit har;"

Cf. Nicander: Samlade arbeten, Tredje upplagan. Förra delen, p. 479. 
completely, with such true conviction, and such pious childlike faith as he."1

But Ling's offensive and defensive tributes to the newly revived divinities did not meet with the same approval everywhere; in fact, the general attitude was probably against him. His efforts met with an enthusiastic welcome by the new "Society for the Study of Art" (Sällskap för konststudium) which took up the cause of Gothism as against classicism. But the Praeses of the old "Academy of Free Arts" (Fria Konsternas Akademi) had publicly condemned the new subjects in the province of art as being "coarse" and "monstrous products of the most ancient northern peoples' imagination." Only those who attended Ling's lectures really knew their sensible contents, for they did not appear in print until two years later. Others judged Ling entirely by his poetic creations, which showed a marked tendency to exaggeration. Consequently, there arose a feeling of apprehension, lest the influence of the dangerous Goth might fill the Swedish studios with Norse monstrosities. The classicists were reminded with horror of the Rudbeckian age when Scandinavian antiquity became the object of ridicule, and before the decade was over it became, for the second time, the target for warning and satire. What was the character of these warnings and satires?

On November 8, I8I7, there appeared in Linköpingsbladet a rather harmless but witty and amusing parody ${ }^{2}$ on the announcement for the Norse prize competition. Here is an example from a suggestion for architecture: The Dwelling of the Blessed with Odin in Valhalla:

"In Odin's chamber there must be his throne, benches around the walls for the Blessed, the fire-place in the middle of the room, and nearby a place where the Blessed at meals may cast the bones after they have gnawed off the meat. Outhouses and especially larders and cellars, must be large enough and the ale-brewery spacious. A place must be marked out where the heroes may exercise."3

1 Cf. Beskow: Life of Ling, as above, p. xxiv.

2 Printed in Hjärne: Götiska förbundet, pp. 149-52.

3 Ibid., pp. 149-50. 
The parody suggests as a theme for sculptors: Ragnar Lodbrok in the serpents' den, ${ }^{1}$ and contains an extremely clever and effectively developed comparison with the famous Laocoöngroup. The comparative method, then, had even crept into the field of ridicule, a method which was adopted later in the more biting and triumphant satire of the Academician Journal.

An interesting and important phase of the outsider's conception of the New School is brought out in one part of this parody. It shows that the characteristics of both the new tendencies were considered present, to a greater or less degree, in one of these literary factions; that is, that the difference between a Goth and a Fosforist was merely relative. This parody, directed primarily against the Goths, becomes a satire on the whole Romantic group, and especially on that phase of it which is attributed to the Fosforists. The part referred to is a satire on a so-called " historical painting.", ${ }_{2}$ The title and introduction may remind the reader of Franz Sternbald reproducing music on his canvas:

St. David hangs his mittens on the sunbeams. "Painting as an art has its origin in Christianity; it is at the same time a Romantic art. Therefore the theme for its exposition may not be taken from ordinary life. The world of heroes is not musical enough for it; its subjects are to be sought where a pious faith elevates the observer from the world of reality to the world of imagination and ravishingly snatches him from the insipidly possible to the forboded supernatural."

then follows a witty attack on Fosforistic pot-pourris of color, mysticism, harmony, "innerlighet," obscurity in style and language, and all intended for the Goths.

In connection with the problem of art and parodies or satires on the same, we are able to corroborate a conclusion in Chapter I, that the Fosforists had distinct Gothic tendencies. One proof of this is Vitalis's ridicule of the Fosforists, in the third decade, which includes some pleasant and inoffensive but keen satire on their fondness for Norse antiquity. It is a parallel

1 It will be remembered that Ragnar Lodbrok was put to death by vipers while on an expedition to Northumberland, England, about 794 .

2 Hjärne: Götiska förbundet, pp. 150-51. 
of the case presented in the preceding paragraph, but in this instance the target is Fosforism, and Gothism is included in it. Vitalis's humorous polemic against the New School was called "The Fosforists in Olympia." It was never completed and is now lost. The fragment, however, was finally published in Östgöta Correspondenten, for I839, by Henrik Palmaer, who knew Vitalis's plans. For our account we are indebted to Forselius, ${ }^{1}$ a friend of Atterbom and Palmblad. It appears that the original plan was in dramatic form and was to contain ${ }_{5}$ acts, for "all the foolishness of the Fosforists could not be included in 5 acts." In the second act Queen Edda appears. "The magic Brynhild form" aspires to Amadis's (Atterbom's) love, but Eos-Sophia (German philosophy) comes forth, shows a copy of Fosforos, and pretends that she alone has the legitimate claim to this honor. ${ }^{2}$ A mortal combat ensues between the two goddesses. Eos-Sophia is pierced by the lance of Edda, but the latter is also wounded and dies, being afterward christened in a wept sonnet. In the fifth act Bacchus and Apollo are conversing on the walls of Olympus. Bacchus asks: "What sort of gnats are those I see coming?" "Those are not gnats," answers Apollo, "those are Fosforists," and interprets the assumed humming of the gnats to be the singing of the Fosforists. As the latter approach a few words can be distinguished such as "ancient groves," "viking-seats," etc.

Even in his poetry Vitalis liked to poke fun at the characters in Norse mythology and those interested in the viking age. In his collected works we find two poems in rimed couplets, dated I824, called "The Rune Frey" and "The Rune Naud," respectively, ${ }^{3}$ their titles being intended to ridicule Nicander's plan of publishing an édition de luxe of his cycle of poems

1 See Forselius: Introduction to Vitalis's Samlade skrifter. Stockholm, I 873 , pp. liiff.

2 It may be Vitalis's opinion that Atterbom's fondness for Norse antiquity was merely a prédilection d'artiste, and we have to admit, of course, that German models were uppermost in his mind, yet Vitalis's proposed comedy presupposes some sort of an interest in the Norse myths.

3 Runan Frey. Fornforskaren. Printed in Samlade skrifter, pp. 23 Iff. Runan Naud. Nordens gudar. Printed in Samlade skrifter, pp. $234 \mathrm{ff}$. 
called "The Runes." "The Rune Frey" had a sub-title, "The Antiquarian" (p. I12, note 3), and satirized the Gothic tendencies to dig into every mound or "mole-hill," and then if you found anything to describe your discovery in Iduna. The antiquarian in this poem sees a number of stones standing in a row; to him they immediately become remnants of ancient viking judgment-seats (domarestenar); a hoary man with "silvery hair" appears who represents the spirit of bygone days and is questioned boldly and solemnly concerning these stones. The expectant interlocutor gets the following prosaic reply from the old man:

\section{Min gunstige herre!}

På denna plats, i min ungdoms dar, En liten badstuga uppbygd var. ${ }^{2}$

Although "The Rune Naud," per se, has no more connection with art than "The Rune Frey," the contents do strike nearer home and are aimed directly at the old Norse gods and their introduction into poetry. Incidentally, Vitalis himself betrays at least a superficial knowledge of the mythology he attempts to ridicule, even if he proudly confesses ignorance about some of the minor divinities. ${ }^{3}$ Vitalis amuses himself in this poem -and others as well-by comparing his own private affairs to those of the Scandinavian gods. Brage had a wife, but he (Vitalis) has none; yet he is glad that he has no gold in his mouth like Heimdall, for then his creditors would come with a

1 Nicander wrote a series of sixteen poems of a national character and at the head of each poem he had some rune inscribed. He planned a vain edition of his "Runes" in his own handwriting with a picture of himself in student's uniform inserted under the rune "Naud," which has as title "Norna-Gest as Youth" (Norna-Gest Som Yngling). Cf. Nicander: Samlade arbeten, Stockholm, 1862, Vol. I, p. 212. Vitalis, who believed his friend had "lost his mind," writes April 3, 1824, that if Nicander's book appeared he would write and inscribe sixteen runes with sixteen caricatures, including his own portrait as "youth with night-cap and poetic coat." See Introduction to Vitalis's works by Forselius, pp. xliiff. Nicander's edition of 1825 , though an édition de luxe, did not have the author's picture and Vitalis's plan also stranded. The only "runes" he inscribed were the two mentioned above. Cf. Chap. V.

2 " My dear sir, upon this spot, in my younger days, there used to stand a little bath-house."

3 As for example: Ali, Voli, Uller, or Forsete. 
surgeon and tear them out. The exact nature of Vitalis's light satire on the Norse gods is best illustrated by examples. I have selected the first, second, and seventh stanzas.

I fall det roar edar, ja och i annat fall, Jag alla gamla Asar för er uppräkna skall.

De upp ur grafven komma, med buller och med bång, Allt för att figurera uti de Göters sång.

Bland dem är Oden ypperst; han blott ett öga bär; På källarn Urdarbrunnen det andra pantsatt är. Slarfaktig i affärer är visst den Ase båld, Han eljest långt för detta löst det ur Mimers våld.

Och blåstens gud är Niord, som skjildes vid sin fru, Kanske han ännu lefver; nog blåser det ännu, Den guden hade fötter så vackra och så små. Hur han såg ut $\mathrm{i}$ synen, har jag ej reda på. ${ }^{1}$

1 "In case it amuses you, yes, even if it does not, I shall enumerate all the Asas for you. They come up out of their graves with noise and bluster, just to figure in the songs of the Goths." "Among them Odin is the most important; he possesses only one eye: the other one is pawned in the tavern Urdarbrunnen (the fountain of time). The bold Asa must be careless in business otherwise he would have redeemed it long ago from the power of Mimer." "And the god of wind is Niord who was separated from his wife. Perhaps he is still alive; certainly it still blows. That god had such small and pretty feet. How he looked in the face, I don't know."

Another author, less important for our purpose, touched on the Gothic tendency in a light, humorous vein. C. F. Dahlgren (cf. Appendix, art. Dahlgren) recognized the saga element as an Old Norse part of the Fosforistic program, and his "The Last Fosforist" (see Samlade arbeten, Stockholm, 1847-52, Vol. I, pp. I42ff.) contains some harmless references to mythologies in general as well as to Icelandic literature in particular. For instance, the Fosforist's coat in this poem is "stitched together of a thousand pieces from India, Iceland, Rome, and Greece." One stanza runs as follows :

$\mathrm{Nu}$ är att säga

Om mythologi'n

Att den bör man äga

I poesi'n

Och ömsom man tage
Än Bacchus än Brage

Än Zeus och än Thor

Än Phoibus, än Frode

Än Balder hin gode

Och än hans bror.

" now there is this to be said about mythology, that one ought to use it in poetry. And you may take, alternately; now Bacchus, now Brage; now Zeus, now Thor, now Phoebus, now Frode; now Balder the Good, and now his Brother." 
The best satire directed against the Norse myths was a long poem by J. M. Stjernstolpe, which appeared in Allmänna Journalen in 1820.1 It was called "The Mythologies, or the Dispute of the Gods" (Mytologierna eller gudatvisten) and deals, in a comparative way, with the assumed characteristics of both the Northern and Southern systems. Naturally, the Greek mythology is taken as the esthetic standard. The plan is ingenious and the contents are positively funny. The gods of Valhalla are sent on a visit to the Olympian deities and held up to scorn and derision. Iceland is taken as the home of the Scandinavian visitors, who appear on Mt. Olympus in all their primitive grotesqueness, accompanied by a full zoölogical retinue of cats, ravens, goats and serpents. ${ }^{2}$ On the arrival of the strangers a great commotion arises in Olympic circles and the goddesses, especially, suffer immense physical discomfort. ${ }^{3}$ Were Odin and his Asas to dethrone Zeus? Iceland is larger than your famous Crete, says Momus to Zeus. ${ }^{4}$ But, on the other hand, chronological priority is claimed for the classic myths and Zeus admonishes the strangers as follows:

1 Numbers 31 and 32 for the 8th and 9th of February. Remember that the editor of Allmänna Journalen was P. A. Wallmark, the publicist, par excellence, of the Old School. As early as August 18 , 1813 (No. 56) there had appeared in Allmänna Journalen a "slightly altered" version of the ancient saga of "Orwar Odder," to show the "dangers of flight" and the advantages of courage and bravery. It can hardly be anything but a thrust at the Goths and Fosforists. The first verse runs as follows:

\section{“ En hjälte det fanns här i Norden en gång, \\ Den störste, som nånsin beskrifvits i sång, \\ Tolf alnar lång, \\ Och Orwar Odder han hetat. \\ Som Viking han farit all verlden omkring \\ Och honom det timat mång underlig ting, \\ Som ännu blott Sagorna vetat."}

Orwar Odd is finally killed in "flight" by an arrow.

2 It will be remembered that cats, ravens, and he-goats were the animals attributed of Freya, Odin, and Thor, respectively. The serpent refers to the so-called Midgard-Serpent, son of Loke and Angerboda, a brother of $\mathrm{Hel}$ and the Fenris-Wolf. With his enormous tail he encircles the whole earth.

3 Venus is thrown into convulsions at the venomous glance of the Midgard-Serpent and Juno gets the stomach-ache. Cf. Hjärne: Götiska förbundet, p. 159 .

4 Ibid., p. 153. 
Dock Asar böra veta :

Långt förr än någon af $\mathrm{Er}$ var, Min blixt kring himlen ljungat har, Mitt namn kring verlden spordes. ${ }^{1}$

For about four months Stjernstolpe enjoyed a certain feeling of victory at the success of his poem, but, on June 21,1820 , there appeared an answer in Anmärkarne, called "The Mythologies, or the Dispute of the Gods. The Second Day." author was a "young" man, but otherwise a complete stranger, says Adlerbeth. ${ }^{3}$ His poem was a "worthy refutation" of Stjernstolpe's anti-Gothic satire. In fact, Adlerbeth goes so far as to claim a defeat for the gods of Greece and Rome as well. "The real value of the poem," asserts Adlerbeth, "lies in the fact that the riders on the wooden beasts (trämärrar) of French literature have been defeated by their own weapon, ridicule. The latter was the last available implement for attacking the ancient Norse myths which they (the worshipers of French literature) were unable to destroy by any serious deductions." And I believe Adlerbeth to have been right. The stranger poet had detected a fundamental difference in the two mythologies which Stjernstolpe either overlooked or ignored. Stjernstolpe had unfairly compared the crude but natural Scandinavian gods with the idealized Greek deities represented in modern art and poetry. In the public refutation, therefore, the Olympic gods are stripped of their artistic embellishments, introduced in their most primitive form and dress, and sent on a return visit to the earth. Mercury suggests that they take this trip in their original, "genuinely divine splendor."4 As soon as unmasked, the Greek travelers present a sad spec-

1 Ibid., p. I62. "But Asas ought to know that long before any of you existed, my lightning flashed through the sky, my name was known around the world."

2 Mytologierna, eller gudatvisten. Andra dagen. Both Stjernstolpe's poem as well as the answer to it are printed in Hjärne: Götiska förbundet, pp. I 52-83, accompanied by explanatory notes. Hjärne's reprint is more easily available to most students and my references are, therefore, to this edition.

3 See letter to Tegnér, dated July I4, 1820. Esaias Tegnér's papper, pp. I30-3I.

4 Hjärne : Götiska förbundet, p. r 70. 
tacle, indeed. The Norse visitors at Olympia were natural, though grotesque; but the Olympians become unnatural, formless monsters, and Jupiter (or Zeus, for the Greek and Roman names are used interchangeably) appears with hawk's head and horns. ${ }^{1}$ Then the anonymous poet adopts a more specifically comparative method and makes such observations as these: Norse mythology has no character with ram's legs like Pan or Silenus; it has no one who is lame like Vulcan, and no maiden with a hundred breasts like the Ephesian Diana. "Awful stories" are found in each and every Greek god's biography, intrigues are frequent, and but few are of legitimate birth. ${ }^{2}$ The Olympian group gets no further than Eleusis before they encounter an enormous herd of pigs. The ass, who understands them without an interpreter, leads the conversation for the Olympians and immediately thereafter Jupiter and his retinue return home disgusted. ${ }^{3}$

As early as $1810-181$ I - the date can be determined approximately by references to European politics-the Academician chief, Leopold, attacked in a poem that national tendency which, as even the anti-Fosforistic Malmström admits, ${ }^{4}$ was common to both Fosforists and Goths. Leopold's satirical poem, of some historical significance and full of sparkling wit, was called "The New Colony, or the Revolution in the Art of Song" (Den nya kolonien eller revolutionen i sångkonsten),,$^{5}$ and was directed against the current eulogies of a former "golden" 6

1 The old images of Jupiter were sometimes represented like those of the Egyptian Osiris, his son, with a hawk-like head, or like Ammon, who appeared to Hercules in the form of a ram. Cf. Lemprière: Classical Dictionary, articles Osiris and Ammon.

2 Hjärne: Götiska förbundet, p. I75.

3 Eleusis had a temple to Ceres, and sows were beasts of sacrifice "at the lesser mysteries." According to one tradition (Hyginus: Poet. Astron., ii, 23) a speaking ass is mentioned in the myth of Dyonysus. Dyonysus was carried across a lake by an ass on his way to the oracle of Dodona. Cf. Dict. of Greek and Roman Biography and Mythology, edited by W. Smith, London, I844, Vol. I, p. 1047.

4 Grunddragen af svenska vitterhetens historia, III, p. 263. According to the poem in question, the national tendency of the Fosforists must have been detected by Leopold before the Gothic School existed, as such.

5 See Leopold: Poetiska arbeten, Uppsala, I873, Vol. I, p. 83, or Malmström: Svenska vitterhetens historia, III, pp. $263 \mathrm{ff}$., where the whole poem is quoted.

6 Malmström : ibid., p. 265. 
age. The poem describes the arrangement of a Sängerkrieg between the nightingale (the Old School) and the recently arrived owl (the New School). "It is about time," says Leopold sharply and sarcastically, "to reinstate, at last, the song of genuine power, which as early as a thousand years ago, was sung by the owls on the mountains of Norway." 1 In the contest nobody would listen to the nightingale and the owl wins, cheered by the whole owl-nation, three hundred voices strong. But every mortal is frightened away, the nightingales resign, and, finally, the owls themselves are gradually driven off. ${ }^{2}$ But Leopold's theoretical views on the employment of Norse mythology in poetry are stated more definitely and severely in his prose treatise on "Ancient Gothic Poetry and the New Taste for this Kind of Literature" (Om den gamla götiska dikten och den nya smaken för detta slags vitterhet), written about I822 or $1823 .^{3}$ What the Gustavian leader believed to hold true in poetry would naturally hold true, all the more, in the plastic arts. On the face of it, this article might seem at first to be a mere warning against exaggeration, for Leopold admits that a taste for Gothic poetry may be commendable 4 and he himself had treated a Gothic theme in "Oden," but that the sagas or Eddas could ever be favorably compared with the ancient classical sources is deemed impossible. Leopold's conception, like that of Stjernstolpe, is one of prejudice and unalloyed preference for the "thousand vivid poetic images of the Greek genius," which in his opinion have become absolutely indispensable to poetic expression in European culture. Norse antiquity to Leopold becomes the "darkest and most uncivilized age," kept at a "necessary" and appropriate distance, i. e., in the

1 Malmström : ibid., p. 265.

2 Ibid., pp. 266-67.

3 Leopold in his treatise speaks of "twelve years of lessons in art," using "art" in a broad sense to signify the poetry of the New School. Now, if Leopold refers to the Fosforists, as such, it would place the date about 1822 , if to the Gothic School, per se, I823. Cf. Malmström: Svenska vitterhetens historia, III, p. 377 , where this part is quoted.

4 Malmström. Svenska vitterhetens historia, III, p. 376.

5 Ibid., p. 383.

6 Ibid., pp. 377-78. 
"coarser and wilder culture of their own age." 1 Gothic antiquity does possess "a more uncivilized sensuality which is adapted for poetic treatment by a talented artist, and is, in itself, good for a change or contrast"; but it ought not to be constantly repeated, least of all with the idea of extruding "the real literature of our own age." 2 Leopold makes an unqualified denial that Gothic antiquity could serve as one of the large, important sources for true poetry. ${ }^{3}$ A Norse motif has the advantage of stimulating attention, for it is only sparsely known, and Leopold himself confesses he has read the old kämpasagas with pleasure, ${ }^{4}$ but the literary form of the manliness and power therein is "undeniably lower" than that of the present age when depicted by a master hand in this "higher splendor."5 That there could be any successful compromise of ancient Norse content with modern form did not occur to the lukewarm, biased chief. $\mathrm{He}$ did not see that his main source of prejudice was more the lack of genius to develop the Norse material, than the material itself, and so Leopold was constantly comparing masters of the Old School with dilettants of the New. That a constant use of the Northern motifs might lead to a "tedious uniformity" was true, as had been exemplified in the poetic works of Ling.

Malmström, literary critic and partisan of Leopold, takes the same classical view; he prefers Greek to Norse mythology and believes that every impartial judge must give the same verdict. "The characters of Norse mythology," says Malmström, "are with few exceptions, rather sublime than beautiful and consequently are not so well adapted for plastic art, and least of all for sculpture."7 Malmström proceeds on the same principle as Stjernstolpe of comparing the highly idealized Greek forms with the undeveloped Scandinavian forms.

I have tried in the last few pages to illustrate the Academician or anti-Romantic opposition to the introduction of Scan-

1 Ibid., p. 384 .

2 Ibid., p. 378.

3 Ibid., p. 378.

7 Ibid., p. 379. Malmström did not have the opportunity to see the recently erected Gefion-fountain in Copenhagen. Gefion was originally, as we have seen, a mythological female character of the Asa-tribe. 
dinavian myths into Swedish art and poetry. It now becomes necessary to retrace our steps to the year I8I7.

The approaching prize-competition with Norse motifs, together with Ling's lectures and poetry, even caused some concern to a leader of the Gothic Society, Geijer. Exaggeration might defeat its own purpose, and Geijer decided to warn against extravagance. The result was the publication in the seventh number of Iduna, I8I7, of "Reflections Concerning the Employment of the Norse Myths in Fine Art" (Betraktelser i afseende på de nordiska myternas användande i skön konst). ${ }^{1}$ It was a landmark of its time and is still well known by students of Geijer. It caused a considerable sensation and even displeasure and was undoubtedly responsible for Ling's resignation from the Gothic Society. ${ }^{2}$ Geijer's "Reflections," their debt to Winckelmann, Lessing, and Herder, as well as their contemporary influence, have recently been quite fully discussed by Adrian Molin in his "Geijer-Studier"3 and to his work I refer for details. It is only necessary here to indicate the main thread of the argument and to add a few personal observations. The whole attitude of the Swedish historian is very classical in its conception of art. $^{4} \mathrm{He}$ holds that sculpture is the least national of the plastic arts; its aim is the universal, and, therefore, Norse mythology is little adapted for a national art. The emphasis is laid on physical definiteness ( sinnlig bestämdhet), and, since it is a "thousand years too late" to determine definite physical form, the only solution is

1 The treatise is found in Geijer's Samlade skrifter (Stockholm, 1874-76, 8 vols.), Vol. I, pp. I $75 \mathrm{ff}$.

2 Cf. letter from Adlerbeth to Tegnér, dated January 6, 1818. Ur Esaias Tegnérs papper, p. 93. Ling would never admit that Geijer's article had anything to do with his resignation. Adlerbeth, in his letter to Tegnér, favors Geijer in this matter and calls Ling's probable attitude toward a different view "most unreasonable." Cf. also Molin: Geijer-Studier, pp. 264-65, and note 2. Geijer, in his article, had referred, rather personally, to blunders in Gothic poetry which provoked some ill feeling in the mind of the super-patriotic Ling.

3 Göteborg, 1906, pp. 244ff.

4 Cf. Blanck: Den nordiska renässansen, p. 432. Molin, however, has detected an influence of Romantic thought à la Fichte, as evidenced by conceptions of the social and political affairs of the time. See "GeijerStudier," pp. $256 \div 57$. 
to introduce the spirit (det ursprungliga) of the ancient myth into the recognized standard form already existing. But with poetry and painting it is different. Although Norse mythology is deficient in "external harmonious perfection," 1 it does possess an inner poetic and philosophical meaning which furnishes a profitable field for the poet or painter. The deities of Norse mythology were, for the most part, characters of action, definite enough for our thought but not for the eye, and they must be represented in their living relation to humanity and may not be isolated from their time or race. ${ }^{2}$ Now, as characters of action they assume human form, such as they have in the sagas, and it is primarily in connection with the heroic saga that the Norse mythological characters may be represented in art. If the motifs are chosen from the Norse myths at all, they had better be developed on canvas rather than in marble.

Geijer's treatise was a well-written and conscientious exposition of his views, and it undoubtedly had some checking influence on the overheated artists of a purely national trend. Molin states, for instance, that the Gothic Society adopted some suggestions from it for its announcements of future prizecompetitions in art. $^{3}$ But time proved that much of Geijer's apprehension was unfounded. He overlooked the fact that a physical definiteness was the result of artistic activity and that, other things being equal, it was just as possible for characters from Norse myths to acquire a definite form as for those of Greek mythology. Geijer commits much the same fallacy as Stjernstolpe in his "Dispute of the Gods," three years later, ${ }^{4}$ that of comparing the developed with the undeveloped. Molin

1 Cf. Molin: Geijer-Studier, p. 25 r.

2 This seems to me to be closely analogous to Leopold's views. Leopold believed that Old Norse culture must be considered, per se, as something foreign and antiquated. Any genuine representation of Gothic antiquity, even in poetry, must be treated as a picture of itself, that is, of its own time, and must be considered too antiquated to re-introduce in any living sense. Granting their premises, and I think we must, we will have to admit that both Geijer and Leopold are right in this respect. Cf. Malmström: Svenska vitterhetens historia, III, p. 378, where this part of Leopold's article is quoted.

3 Molin: Geijer-Studier, p. 266.

4 Cf. above, pp. II $5 \mathrm{ff}$. 
still contends with Geijer, however, that, so far as sculpture is concerned, such a development could only take place, as in the case of the Greek, "before the myth became a myth," that is, while it was still a living, religious conception of the people. ${ }^{1}$ The creations of Fogelberg seem to be an exception to the rule, according to Molin. ${ }^{2}$ But the very exception proves that such a development is possible when undertaken by a real genius.

Tegnér, it seems to me, gives the best common-sense solution of the problem. ${ }^{3}$ He pointed out that originally the forms in Greek mythology were as crude and indefinite as those in question, and had they been limited to mere poetic treatment they would not have been any more definite than the Scandinavian ones. ${ }^{4}$ And not only that, but where can you draw the line between saga and myth? There is no sharp line of demarcation, and if you concede that the heroic saga may be employed in art, how can you consistently bar the myth? Human art has no better type for either heaven or earth than the human type. Divinity is merely an idealized human form, as far as plastic art is concerned. Granting this, Geijer's treatise loses some of its force. It was a question that could not be answered by any theoretical or philosophical deductions; it was a practical problem and the sole method of solving it was by actual attempt. ${ }^{5}$ Tegnér writes to Leopold, February 7, I822:6 "It is true that the so-called Gothic poetry has up to this time been a failure in Sweden; but if we, who have failed, were only really honest, we would admit that Thor, Odin, and Frey and all the old fighters are absolutely innocent in the matter." In other words, it depended upon the poet or artist whether the Norse myths could be made worth while, a view which Tegnér himself proved sufficiently, as far as poetry was concerned. Tegnér, also, did not like Geijer's plain reference to Ling's poetic mis-

1 Molin: Geijer-Studier, p. 264.

2 Ibid., p. 266.

3 Cf. Geijer-Studier, p. 264, for Molin's criticism of Tegnér's opinion in this matter.

4 Cf. letter by Tegnér to Adlerbeth of July 5, 1818, for criticism by Tegnér of Geijer's article. Jubelfestupplaga, V, pp. I54ff.

5 Cf. letter by Tegnér to Adlerbeth of December 21, 1817. Jubelfestupplaga, V, pp. r 3 Iff.

6 Jubelfestupplaga, V, p. 243. 
takes. Nobody was more conscious of the mistakes than Ling himself, and one ought to use some indulgence towards a product (referring to "Gylfe") upon which so much seriousness, genius, and art had been spent. ${ }^{1}$

Even in plastic art there was no such danger in Ling's preachings as was at first supposed. In fact, I am unable to detect any essential difference of viewpoint, even between Geijer and Ling. It was a relative difference rather than a fundamental one, a fact which is clearly brought out in "Symbolism of the Eddas" which we have already discussed. ${ }^{2}$ Like Tegnér, Ling leaves much to the artist, and it was never his intention to offend the sense of beauty by recommending indefinite monsters to be done in marble or on canvas. Fully recognizing the experimental stage of a national art, he proceeded cautiously to give hints to prospective painters and sculptors, in order to establish gradually a definite physical form for his beloved Scandinavian characters. I doubt very much whether Ling ever expected to see a perfected Norse type immediately. $\mathrm{He}$ was on the right track; the Scandinavian gods were already partially idealized in his mind, like the Greek gods in the mind of the Greek artist, and he never thought of advocating anything but the perfected human form for divinities. ${ }^{3}$ But the human form is the form of the heroic saga as advocated by Geijer, so where is the dangerous radicalism or cause for alarm? Ling himself asserted that the highest god or Allfather, who was not conceived by our ancestors in sensual, that is, human form, could not be represented in plastic art like the other nature-divinities. ${ }^{4}$

The efforts of Ling and his disciples were crowned with more practical success than was ever anticipated in the first public exhibition of the new art, held in the Kirstein House,

1 See letter by Tegnér of July 5,18 18. (See p. 122, note 4 ).

2 To be sure, the "Symbolism" did not appear in print until 1819, two years after Geijer's article, but it was an independent résumé of Ling's own lectures, held from $1814-17$, and could never have been influenced by Geijer.

3 Cf. Ling: Samlade arbeten, II, pp. 443-44. Cf. also above, p. I07.

4 Ling: Samlade arbeten, II, p. 446. 
in Stockholm, beginning the I9th day of May, I8I8. ${ }^{1}$ All artists were invited to participate. Attempts had been made to frustrate the plans for the new exhibition but to no avail. The catalog of one thousand copies went into a new edition and the time of the exhibition was prolonged by request. The innovation was a financial success also. Even royalty patronized the exhibition and His Majesty the King ordered Fogelberg's models of the Norse gods to be executed in marble for himself. In the "Addenda," in the eleventh number of Iduna," we have the names of the winners and the amount of the prizes in the Norse art-competitions from 1818 to 1822 , as well as the name and character of the artistic production in each case. For instance: Alex. Malmquist is awarded a prize of 20 ducats for an oil-painting of "Brage and Idun," and P. Berggren a similar amount for a representation of "Odin at the Spring of Mimer."

No one rejoiced more over the success of the exhibition than Tegnér. He writes to Adlerbeth, August 20, I818:3 "It makes me rejoice heartily that the Gothic Society's exhibition was such a success." He hopes it is demonstrated that the reawakened feeling for ancient Norse is not an insane idea or merely a passing mania, "but that it can and ought to express itself in permanent creations, either in song or marble, and thus lay the foundation for an independent, national art."

1 See "Berättelse angående den af Götiska Förbundet anställda konstexpositionen 1818 ." In Iduna, Vol. XI, pp. 82ff. Vedel is scarcely correct when he characterizes (see "Svensk romantik," p. 260) the result of this exposition as "not gratifying."

2 "Tillägg, rörande de af Götiska Förbundet anställda taflingar i behandling af nordiska myther $\mathrm{i}$ bildande konst, samt konstexpositionen 1818," pp. 97-99.

3 See Jubelfestupplaga, V, p. 160.

4 Tegnér recognizes, as seen in this letter, that plastic art is universal in its essence, as Geijer had urged, and that European culture which "more or less grinds off all nationality" would have to be taken into account, even if it did not seriously hamper the development of a national art. 


\section{CHAPTER IV}

Erik Johan Stagnelius : The Old Norse Element as a VEHICLE FOR ROMANTICISM

Ât sången invigd re'n som barn jag var, Min själ förtrogen med naturens under. I grottors skymning, rosenlundars sköt, Der silfverkällor, musikaliskt runno Och näktergalen ömma toner gjöt, Då etherns lampor öfver jorden brunno, Bland väna trollmör der, med kransadt hår Och kinden smekt af milda vestanväder, Hur lyckligt flöto mina barndomsår!

Kwaser in "Gunlög."

The most thorough Romanticist in Sweden was the young and suffering Stagnelius. Both his life and work point him out as the natural exponent of what is deepest and most typical in Romanticism. He did not have to affiliate himself with any new school to be called Romantic. He did not have to take part in any polemics to advertise his theories. Stagnelius was something more than an obscure theorist; he was primarily a creator. He loved to produce and what he produced came spontaneously, without undue effort or adherence to any set literary dogma. He was always independent. He educated himself by persistent browsing in his father's library, wrote independently, lived alone, and finally died alone at the age of thirty. ${ }^{1}$ $\mathrm{He}$ was an original, self-taught savant, to whom both the Northern and Southern mythologies were equally familiar. We may call him a Romantic genius. Mystical yearning, personal suffering, deep pathos, "singing eloquence," and characteristic coloring are nowhere better exemplified than in the poetry of Stagnelius. No one understood better than he the deeper significance of myth and religion, and the constant strife between

1 Cf. Appendix: Note on Stagnelius. 
matter and spirit, as pictured both in myth and religion, is a favorite theme of our poet. Sensuousness, in a carnal sense generally, is a striking quality of much of Stagnelius's poetry. Woman is the crown of nature and at the same time the most dangerous phenomenon in the universe; not even the gods can escape her artful cunning.

These are some of the characteristics noticeable in Stagnelius's treatment of Gothic themes. In other words the saga element becomes a vehicle for the Romantic, the didactic, and the autobiographical. But the vehicle itself is as important as the rest, and one is a spontaneous supplement of the other. There seems to be no militant effort to emphasize either one, and yet both are sufficiently prominent. Stagnelius's Gothicism is found in conjunction with Romanticism, then, in a more restricted sense, and Hellenism. These three the poet weaves together into a lyrical fabric of the most dazzling colors and pleasing melodies.

The saga element, though not intentionally obtrusive, is conspicuous in the very titles of Stagnelius's poems. "Gunlög," "Wisbur," and "Svegder" are recognized immediately as familiar names from the prose Edda and the Heimskringla. "Sigurd Ring" calls up the semi-historical exploits of a mighty pagan king, and "Blenda" reminds us of a period in Swedish history when harsh viking measures were not yet forgotten. Of these five works "Gunlög" is a fragmentary epic; "Blenda" is an epic, technically finished but intrinsically incomplete; "Svegder" is a dramatic fragment; and "Wisbur" and "Sigurd Ring" are short tragedies in the Greek style with choruses. In all of these we observe both a general enthusiasm for the saga age and an effort to interpret specific myths or characters. A favorite Romantic theme, like the origin of poetry in "Gunlög," gives the author opportunity for a more lengthy discourse, and here we must study the author himself in terms of Norse mythology. But the Norse element is never a mere rhetorical ornamentation, a superficial jumble of names; it is always a thoroughly digested part of a poetic nutriment. It is a background blending harmoniously with the poet's modern reflections and feelings. 
All of the above-mentioned productions were written during the last eleven years of the author's life, but none of them were published until after the author's death in I823. In taking up his Gothic themes more in detail one need not pay much attention to chronology in composition, and but little is known about it with certainty. We shall consider "Blenda" first.

"Blenda" is a "Romantic Poem in Five Cantos" and is written in rimed, iambic verse of varying length. It is based on an old saga-like tradition, of which one form goes back to heathendom and the other, the one which Stagnelius used, goes back to a later narrative. ${ }^{1}$ In it the patriotic Blenda, at the head of a band of Swedish women, attacks and slays the common enemy, the Dane. The scene is laid in the district of Wärend in the province of Smalland, and the enemy comes from Skane in the extreme southern part of Sweden, which then belonged to Denmark. In Stagnelius, also, the scene is laid right after the introduction of Christianity, and Blenda has become a demonic Judith who, for personal reasons, takes a horrible revenge on the Danes. With the Venus-girdle as an allurement, the amorous swains are enticed into camp and cruelly murdered.

Since the poet does not localize his action in the real saga age, the viking element becomes epic and general in character. Some events are given in terms of specific Norse myths, and comparative references are made to them occasionally, but otherwise it is merely a general glorification of the manly viking exploits and character. It is the effeminateness of the modern age and the sturdiness of the past that are contrasted, much as in Nicander and Beskow later. But Stagnelius makes a very ingenious plan. An unflinching bravery, like that of the heathen forefathers, is at first extolled, then aroused in the lethargic Christian warriors, who sail away at once across the Baltic to fight the pagans in Livonia. A curious put plausible plan: by pagan methods the pagans themselves are to be converted to Christianity.

The eulogy of the saga age is found in the beginning of the first canto, in Alle's rousing speech to his warriors. These

1 Cf. Introduction by Hammarskjöld to Stagnelius's "Samlade skrifter," Stockholm, I836, p. 32. 
have spent nineteen years in drinking, eating, hunting, and courting the favor of women. But their heathen ancestors did otherwise. In the early spring as soon as the snow had melted, they set out over the sea "to conquer or die," while "many a lonely maid stood waving a farewell with swan-white kerchief in hand." During the whole summer the viking roved about the world. He sunk fleets and broke down strongholds, rich coasts were burned and "the water-sprite blushed with blood." Scarcely had the leaves begun to fall, when the viking boats came back laden with plunder. The faithful maiden welcomed her champion, the lighted torches illumined the castle, and the drinking-horn and string-instrument contributed to the celebration. These were happy times for lovers; "there were no limits, no laws for men whose right arm was their only god," and no priest could condemn them. But since the "white Christ" came into the land, all has changed: the weapons rust, the ship decays, and ancestral manliness is buried forever in the ancestral funeral-mounds. The road to exploits and strength is closed and life has become one eternal monotony. But the viking methods must return, even if "the age of the saga is past and the heavenly kingdom has driven out the glorious Valhalla." Again swords are to flash and cloven hearts bleed, though no sacrifices glow on Odin's altar.

Thus Alle continues. Then he makes a specific appeal for vikingism to his oldest son Adolf who has fallen in love with Blenda. Alle does not blame his son for entertaining a passion for a woman, but he must win his beloved in a manly way. In olden times bravery often went hand in hand with love, but success in love could follow only as a reward of bravery and the heathen maiden often girded on her lover's sword. ${ }^{1}$ The vik-

1 Cf. the following strophe (29) from "Sång till quinnorna i Norden" by Stagnelius :

O sköna tid! i Sagans ljud

Blott ännu lefvande på jorden,

Då ynglingen i höga Norden

Till hjelte valdes af sin brud!

Hans dygder inga skranker funno,

Och modet kände ingen gräns.

O sköna tid! då kärlekens

Och ärans eld förente brunno! 
ing was not tormented by weak emotions; he rushed through arrows, swords, and fire to win his prize. "The beauties at that time sat in high ladies'-bowers, surrounded by dragons and firm walls and could be won only by deeds and perfect manhood. Thus Ragnar Lodbrok won the hand of Herröd's daughter. And so, only when Adolf returns a victor from war, may he think of love. The joy will then be double.

In the third canto Stagnelius introduces another link which connects the modern epic with the pagan tradition. It is the inexorable Norse fate and the fulfilment of a prophecy. Eight generations back a Northern sibyl, "a century-old maid with wrinkled face and locks of snow," had appeared at Blenda's ancestral castle. To the beautiful Gerd a daughter had just been born, but the brave and stern Grim had demanded of the gods a son. Incensed, he determined to cast the child before the ravens upon the heath, and the death of the daughter seemed assured, when the sibyl appeared, drew forth a dagger, and rebuked the angry parent in the following prophetic terms: "With this dagger, a woman of this race shall save Sweden and conquer Jutland." The daughter was allowed to live, and the pagan instrument had then been handed down from mother to the oldest daughter for seven generations until now, finally, it was delivered into the hands of Blenda by her father. A miraculous power-we may call it fate-connected with a certain mechanical instrument from heathen times, was now to do its work through the agency of a Christian maid. A curious but beautiful and broad-minded thought: Norse paganism and Christianity in unison, and the latter the glorious fulfilment of the former.

Stagnelius tried his hand at humor in "Blenda," but was not particularly successful. His expressions of humor are too realistic, often indelicate and in bad taste. Atterbom called "Blenda" a "half-wanton Wieland epopée," due to the author's early studies of "Idris" and "Oberon."1

The plan of "Blenda" was probably earlier than that of any other work of Stagnelius, but it was not finished until about

1 See “Literära karakteristiker." Senare bandet, Örebro, I870. Recension of Stagnelius's works, pp. 5i-52. 
1816. ${ }^{1}$ The first product to be finished-if we may use that term in speaking of a fragment-was the epic "Gunlög," the greater part of which was written in I812. Here the satirical element was present in the original source but in Stagnelius's epic it is much suppressed. The rough, grotesque, and grossly satirical gives way to a lyrico-epic "height and dignity." The pleasant Romantic elements are more prominent. Everything is colored in purple, rose, or silver, and bathed in moonlight in a "gloomy pine-forest." It is less clear and more subjective than "Blenda" but the style and form" are better. First a word about the original source.

"The Tales of Brage" (Bragarœður, Chapters 3-4) in the Snorre Edda give us two distinct parts of the original myth: (I) the origin of Suttung's mead, and (2) Odin's capture of it, signifying the origin of poetry and how it became the property of the gods. The divine Asas and the Wanes had a war with each other. They came together to make peace and spat their spittle $\mathrm{e}^{3}$ into one vessel, and out of this they created Kwasir, who was so wise that he could give advice in all things. Kwasir was killed through treachery by the dwarfs, Fjalar and Galar. His blood was collected in two pitchers and a kettle, mixed with honey, and a mead prepared from it, and he who drank thereof became a poet and a sage. Once the same dwarfs caused the death of the giant Gilling and the mead was given as indemnity to Gilling's son, Suttung, for the death of his father. Suttung had the mead brought into the mountain Hnitbjorg, where it was guarded by his daughter Gunnlod (Gunlög). This is the end of the first part. Then Odin, under the name of Bolwerk, comes to Suttung's brother, Baugi. He brings about the death of his nine servants and offers to take their place in return for a drink of Kwasir's (i. e., Suttung's) mead. Odin stays through the summer but in the winter he demands his reward. Suttung refuses Odin and Baugi the

1 It was probably written immediately before "Wladimir den Store," which appeared in 1817 .

2 It is written in easy-flowing, regular rimed pentameters with alternating masculine and feminine rimes.

3 The spittle of the Asas and Wanes represents the spiritual and the formal in poetry, respectively. 
coveted draught; and so Bolwerk (Odin) takes an auger, bores a hole through the Hnitbjorg mountain, changes himself to a serpent, and crawls through to Gunnlod. He spends three nights with her, gets three draughts of the mead, and empties all three vessels. He then returns as he had come, assumes the shape of an eagle and flies away. $\mathrm{He}$ is pursued by Suttung, likewise in eagle form, but Odin arrives home in time to eject the mead into vessels stationed in the yard for the purpose, and Suttung has to be satisfied with a few drippings from behind. From now on the poet-making drink is the property of the gods alone.

We can easily see how a thorough Romanticist would revel in such a theme. Beneath the external crudeness of the Norse myth we have the profound meaning; the divine ownership of poetry. It was this theme which appealed to the young Stagnelius, as it did to so many German Romanticists. The poet was on a par with the gods and his art was a divine art and of divine origin. Consequently the humorous element in "Gunlög" is less developed, the crudeness is to a large extent removed, and the details of the original are altered ${ }^{1}$ to suit the main purpose: the apotheosis of poetry. Then also it becomes the struggle between the powers of light and darkness, i. e., between the Asas and the dwarfs, and the former must conquer. Wickedness is punished, for the norns are ever watchful, and specific violence against the sons of poetry is eventually avenged. "Gunlög" eulogizes also the magic power of music. Music is the art, par excellence,-and how Romantic this is,which can soothe the restless soul and arouse the warriors to action. Stagnelius's epic has become the carrier for expressions of tender moods and melancholy, for elegiac effusions, for didacticism, and for highly colored descriptions. Much emphasis is laid upon the history of the creation according to the Norse myth and references are made to semi-historical facts and viking customs.

The epic "Gunlög" comprises four complete cantos with fragments of a fifth and sixth. The first canto deals with Kwasir's divine calling as a poet, his war against the Asas.

1 For instance, Stagnelius uses only one vessel to collect Kwasir's blood. 
Kwasir has been brought up by Northern fairies "near sacred springs in the quiet grove." At seventeen he goes out to sing of the glory of the gods; to spread life and pleasure through the almighty power of song and music; and to sing of weapons and of the golden age when all was innocent. ${ }^{1} \mathrm{He}$ arrives at Asa-gard where he "shines like a star." Here he tells of Odin's beneficial immigration into the North and either sings mildly of death, or the strings of his harp " roar forth the thunder of war" and arouse the desire for murder. In the interim, Suttung, who reigns in the extreme North at Hnitbjorg, hears that foreign vessels have arrived on the shore of Manhem with new gods and religious services and decides to fight them. Clubs and bows and arrows are to be used "after the custom of the forefathers," "shields are cleaned with sand and bearfat," and the edges of steel sharpened on smooth rocks.

In the second canto Kwasir arrives at Suttung's court, his countenance beaming with "divine enchantment." With him is the warrior Brage who comes as a special messenger from Odin to sue for the hand of Suttung's daughter, Gunlög. The skald sings of his youth, ${ }^{2}$ his divine gift, and of the creation of the world. But Suttung is enraged, he is only temporarily pacified by the magic power of Kwasir's music and determines "to drink intoxication out of the Asas' skulls," much as the forefathers were wont to do. ${ }^{3}$

The third canto is a beautiful and sublime mingling of the Romantic and the Gothic. Here we find gods and dwarfs, dreams, pathos, miracles, caves, and moonlight. Brage and Kwasir descend into a cave on a mountain to rest. Kwasir dreams. He realizes he will not live much longer, and so comes out upon a cliff near a lonely shore and sings his best songs. He tells of the dwarfs and of their partial destruction by Asa-Thor. And, alas! two dwarfs who had their forge beneath the mountain were annoyed by Kwasir's harp-" the breast where dwells the hunger for gold" is immune to the magic power of song and fraternal sympathy-and capture the

1 Cf. Ja, säll var jorden innan Lokes brott

Och Höders blindhet hunnit Balder fälla, 11. 8I-82.

2 Cf. quotation at beginning of chapter.

3 Cf. lines 248-49. 
minstrel. He is bound naked to a marble pillar and murdered. But the divine norn is present. She removes the corpse to save the skald from disgrace, his sacred blood is changed by a miracle to a golden yellow mead, and, together with the harp, is deposited in the lowest part of the grotto.

In the fourth canto the dwarfs are executed for not having a suit of armor ready which they were forging for Suttung, and thus the death of the skald is, in a sense, already avenged. Suttung makes further preparations to reconquer Manhem from the new gods. The army eats bear-steak prepared in copper kettles, and a mead is prepared from honey and hops. Then the dwarfs' grotto is plundered. Hjalmar, a character invented by the poet, is led by fate to Kwasir's blood or mead. He had before the making of a poet; now he becomes a real skald. His vision includes new worlds, his feelings melt together into a symphony, and everything becomes purple and gold. Through the winds of the night, among the tall pines and in a silvery moonlight the heavenly tones issue forth from his harp. The gates of heaven are now truly open to him. Suttung hears the harp and, angered, pursues the skald, but the latter is protected by the norn. It is now that Suttung procures the wonderful mead and decides to entrust it to the care of his daughter Gunlög. She is to be the custodian of it at the castle of Hnitbjorg until her father's victorious return from the war with Odin. In the meantime Brage has disappeared-the poet does not make it clear when-and returns to Odin with the tidings, while Suttung goes to sleep listening to Hjalmar's harp. Then Thor is given command of the Asatroops, for love and longing has deprived Odin of the necessary energy to carry armor. Thus the poet:

Så stämmer kärlek hjeltars styrka ner, Så äfven Gudar tråna för begären. ${ }^{1}$

The favorite thought of Stagnelius, that woman is the cause of the downfall of both men and gods, is well illustrated in the fragment of the fifth and sixth cantos. The wise Mimer

1 Thus love takes away the strength of heroes; thus even the gods yearn for desires (i. e., the passion of love). 
points out that the Asas will never conquer Jothem unless they obtain Kwasir's golden harp to arouse the men to courage. How is this to be done? Freya's maid Lofne is selected to entice Hjalmar by womanly cunning which can do anything in the world. Hjalmar resists the temptation for a while, but finally yields passionately, Lofne obtains the harp, and arrives at Odin's castle with it. The last part of the fragment deals with Odin's visit to Gunlög. It is extremely passionate, naive, and suggestive. In the morning after his nocturnal sojourn, Odin drinks the mead, embraces his sweetheart again, assumes the form of an eagle (as in the original source), and flies away. In Asa-gard he ejects the mead into a beaker which "rings melodiously at every drop." Brage, who has been waiting for him, drinks it and now feels a higher divinity burning in his heart. His glance is directed toward the canopy of the stars and he is crowned king of skalds. The Jota-army is crushed and driven into the far North where they live as Lapps. Hjalmar gets a place among the skalds and Gunlög becomes the wife of Odin.

It is clear from the above analysis that in "Gunlög" Stagnelius was most interested in the purely poetic, the personal, the feminine, and the Romantic. He molds the myth to suit his will. In the next work to be considered we shall notice a somewhat different attitude.

In no production has the poet followed the original source as closely as in "Wisbur." In this short five-act tragedy our attention is focused upon the original narrative, as given by Snorre Sturleson in the Ynglinga Saga. Fate, which played a secondary part in "Blenda" and "Gunlög," becomes the principal motive in "Wisbur." A curse like that upon Andvari's treasure in the Völsunga Saga rests upon our hero. It is the necessary expiation of old sins and the unavoidable repetition of the same which gives the tragic setting. It is a logical Hellenic-Gothic sequence of sin, curse, blood, and tears. Then Stagnelius weaves into his fabric the danger of ambition, the superiority of lowliness to greatness and honor, and emphasizes again the power and character of woman.

It will be remembered that Livijn had in mind a trilogy on the 
saga of Wisbur (Visbur), but it was never written. The main facts of the original form of the saga have, therefore, been given already. ${ }^{1}$ We shall see that the story in the drama coincides on the whole with the original.

The enchantress Huld gives us the past history of the fatal chain, now worn by Hildur. The golden chain had once been the property of Odin's wife. It was made by the dwarf Sindre, it had the property of producing nothing but strife and war, and had been stolen by Loki for the destruction and enticement of all the gods' children. It was promised by Vaulande, Wisbur's father, to Drifva in Finland, but Vaulande was faithless, and died as a consequence, through his former sweetheart's revenge.

Now the situation becomes analogous in Wisbur's own case. His first wife Öda has been deserted. He has two sons, Gissler (Gisel) and Auder (Audur), by her and the chain and throne should belong to them. Öda appears at Wisbur's court at Uppsala to claim her just dues. A large feast is being prepared to which all are invited, including the two sons. The gods do not seem propitious but Wisbur goes blindly on. Öda's request is refused, and Wisbur declares honestly and directly that he does not love his former wife any more. Whereupon Öda becomes a raging animal, a ferocious Penthesilea, who would gladly "drink blood as she drinks the frothing mead." After a consultation with Vanlander's (Vaulande's) spirit, the reigning couple are made acquainted with the pending catastrophe. Soon crowds appear, surround the castle, and capture it. Hildur, in despair, chokes herself with the cursed chain, Wisbur falls on his sword. Auder comes on the stage with the coveted jewel, and now Öda is ready to die.

In the original the chain is mentioned only in connection with Wisbur (in Chap. I7 of the Ynglinga Saga), and the former history of the neck-ring is not mentioned at all. Stagnelius supplies the name, also, of Wisbur's second wife; the saga tells us merely that he "took to himself another wife." Likewise the details of the catastrophe have been altered to suit the dra-

1 Cf. Chap. I, p. 72, where the original narrative is given. 
matic situation; but the fundamental motivation of the original source has been preserved.

"Wisbur" is a marvelous harmony of Gothicism and Hellenism. Of course, it is primarily a lyrical reading drama; and for this reason the choruses are very prominent and contain perhaps the most beautiful poetry in the tragedy. Here the Hellenic-antique, however, overshadows the Scandinavianantique. And what wonderful harmony here of form and content! Öda makes her awful, revengeful resolutions in ominous dactylic tetrameters ; ${ }^{1}$ when Wisbur's castle is surrounded, the chorus gives us the details in rapid dimeters, alternating with tetrameters $;^{2}$ the combat between father and son is told in exciting iambic tetrameters $;^{3}$ and a temporary calm after the storm is indicated by alternating tetrameters, and trimeters of the dactylic foot. ${ }^{4}$ The main argument is written in the modern blank verse with little action and, like the author's other works, with much coloring of rose, lily, purple and silver. The mild sighs, moonlight and mystical yearning of a Romantic atmosphere are not wanting.

Stagnelius has put some thoughts into the minds of the characters Wisbur and Hildur which may well have an autobiographical application, especially when we know of the poet's own mental and physical suffering.

Hildur, in the first act-we may well call it a mere scenesays: "It is easy to die but cruel to tremble eternally." No doubt the poet felt the truth of this assertion. Again, in the fourth act, after Hildur has announced the decreed doom to come, Wisbur answers with a grim humor:

\footnotetext{
1 Cf. Ormar från Nastrand! sliten mitt bröst! Spruten ert gift i mitt rasande hjerta!

2 Cf. Ack! lössläppt är fejden;

En rasande tiger,

Snart fråssar den grymme på likströdda torg.

3 Cf. Det vilda hafvets raseri

Och stormens vrede tyglen I-

Kan menskan blott ej hugnad bli?

4 Cf. Stjernorna blänka så mildt $i$ azuren

Blommorna sofva i dalen.

Lugn är den eviga, hulda naturen, Andas blott njutning och väl.
} 
Med döden alltså endast? Goda Hildur! Visst skall jag dö; jag visste det förut.

Den höga Oden före mig ju dödde,

Han, Valhalls konung, alla diars hufvud,

Den rika Niord, åkerbrukets Gud,

Och Yngve Frey, den gyllne tidens drott,

Och Fjolner, Svegder, och min far Vanlander.

Ej annat öde kan jag vänta mig. ${ }^{1}$

Incidentally we get, at the same time, a good sprinkling of names from Norse mythology.

" Sigurd Ring," another short tragedy in pentameters, is very much like "Wisbur." The formal characteristics are the same; the unities are observed, the characters few, and choruses extol the heroes and heroine. There is little action; most of it is epic and lyrical. It has dramatic episodes of touching intensity, but it is too brief for a stage play. It has the usual amount of Romantic epithets and mystical longing, and evinces the most stirring pathos. No Gothic work of Stagneliusperhaps none of his works-depicts such intensity of feeling, it seems to me, as "Sigurd Ring." And the almost imperceptible blending of realism and lyricism in the tragedy proves unmistakably that the author is a poet of genius.

Again, "das Ewig-weibliche" plays an important rôle. In fact, it seems as if the poet at times were more interested in the heroine than in the hero. The tragedy could just as well have been called "Hilma," the name of the heroine, as "Sigurd Ring." How Stagnelius delights in the glorification of womanly beauty! Beauty is god-like, and the terms used in describing that of woman are frequently-and naturally-compounds of "snow" and "lily." As in "Wisbur," there is a personal note, an evidence of the poet's own suffering. In Act III, for instance, there is much about hope, patience, and a silent resignation to whatever fate may have in store for us.

1 [And so you come to announce] Death only? Why, my good Hildur! Of course I am to die; I knew that before. Why, the high Odin before me died, he, the king of Valhalla, the chief of all the gods. The rich Niord, the god of agriculture; and Yngve Frey, the king of the Golden Age; and Fjolner, Svegder, and my father Vanlander; no other fate may I expect. 
The Old Norse element in "Sigurd Ring" is different from that in "Wisbur." In the former the original source is more truly historical and the emphasis, therefore, laid more upon viking characteristics than upon pure Norse myths. The viking qualities are idealized and accounts of them clothed in elevated language. The Northern pirate's directness of speech and uprightness is well illustrated. A promise once made is always kept. A death on the battlefield, either self-inflicted or at the hand of another, is the ideal death for an heroic viking, and the blue dwelling-place of the water-sprite is a charming grave for a Norse woman. And this has divine sanction. That Alf dies on the battlefield with Sigurd's sword, wielded by Sigurd himself, is not only desired by Alf, but decreed and fulfilled by the fate of the gods. In addition to the strictly viking element, also, we have much of the poet's reflection in "Sigurd Ring," expressed in terms of Norse myths. In illustrating the tremendous power of love (in Act II), Stagnelius introduces again-and this time he follows the original myth more closely - the story of Suttung's mead. That is, he uses that part of Norse mythology which best suits his Romantic temperament.

Sigurd Ring was one of the last kings of the mythological age of the North. He made himself the ruler of all Scandinavia by the defeat of Harald Hildetand at the memorable battle of Bråvallahed in Småland, Sweden, 730 A. D. This was the last battle in which Odin himself is said to have appeared on earth, and most of the nobles and heroes of the whole North met in combat. ${ }^{1}$ The victory of Sigurd Ring over Harald Hildetand is mentioned in Saxo Grammaticus in the eighth book.

The scene of the original story of Stagnelius's tragedy, according to Hammarskjöld, ${ }^{2}$ is laid in Norway, and Alf-sol (Hilma) is the daughter of a sub-king of Norway. Here Sigurd, king of Svithiod (Sweden), sues for the hand of Alf-sol but is refused by the father and brothers on the ground of old

1 Cf. Paul C. Sinding: The Scandinavian Races, New York, 1875, pp. $47 \mathrm{ff}$.

2 Cf. Introduction to Stagnelius's "Samlade skrifter," Stockholm, 1836, pp. 36-37. 
age. Then, as had been the viking custom, Sigurd resorts to force. But since Sigurd is a mighty and feared warrior, the brothers anticipate the outcome of the encounter by giving their sister poison before the fray opens. When Sigurd finds her dead he dies himself, "as he had lived, among the billows and flames."1

Stagnelius localizes his tragedy in Denmark in the province of Jutland, and the action which we see takes place in a colonnade-hall in Alf's castle. The name of the heroine is Hilma; Alf is her brother and guardian and under-king of Jutland; Ragnar is a hero and Hilma's accepted lover; and Sigurd, as in history, is an old man and king of Sweden, Norway and Denmark. The tragic conflict, as in the original, is between genuine love and earthly power. It is duty, sworn friendship, and honor against splendor, high position, and faithlessness. Hilma does not care for happiness in the ordinary sense; she wants a heart, and is, naturally, willing to die for her love.

The plot is very simple. Sigurd, who has always been victorious in battle, demands the hand of Hilma from her brother. The old king is straightway rejected, for Alf refuses to break his word that Ragnar shall possess her love. The refusal means war, and war under the circumstances means the defeat and probable death of Hilma's protectors. And so Hilma takes the poison prepared for her, and in the presence of her lover, Alf and Ragnar are both slain in the battle that follows, Sigurd himself commits suicide, and the bodies of Sigurd and Hilma are burned on the same funeral pyre upon the monarch's ship.

That Stagnelius had the power to create a scene of dramatic beauty is proved in the fourth act. Sigurd is just returning with the blood of Alf and Ragnar upon his conscience. $\mathrm{He}$ has sent thousands to Valhalla before without the slightest feeling of compunction, but the last deed worries him. In the meantime the body of Hilma has been prepared for the last

1 For his own source, Hammarskjöld refers in his Introduction to "Sveriges historia för ungdom," by M. Bruzelius. I have not seen this work myself. 
rites and is lying in state. Gerda, the fostermother, tells Sigurd, who knows nothing of Hilma's death, that his bride is waiting for him in wedding array, calm, silent, and smiling. The subsequent scene, when Sigurd discovers the real state of affairs, and the heroic lamentations of the old viking king at Hilma's bier produce a dramatic situation of immense power.

The poet's own hopeful and serene view of the life to come finds a suitable expression in "Sigurd Ring" in terms of Norse mythology. The tone is that of a deep religiosity and faith in a better eternal life. The chorus in the last act sings first of the final destruction of the world. Then, last of all, it sings of the eternal bliss to come, when evil is no more; when Balder and Nanna return from the subjugated kingdom of $\mathrm{Hel}$; and when the Asas discover anew in the green grass the divine runes of Allfather.

That Stagnelius knew his Norse mythology and understood its profound meaning perfectly, is nowhere better illustrated than in the interesting, seven-page dramatic fragment "Svegder." In the original source the poet found the very essence of the moral and religious struggles of mankind. He found his own agonizing, Faustian struggle of two souls, diametrically opposed to one another, dwelling in the same breast. Here was the golden opportunity to dwell on the everlasting war between matter and spirit. Here the poet found a vehicle for symbolism and philosophy; here, again, woman becomes the only conqueror of gods; and back of it all are the blind, incomprehensible judgments of fate.

The narrative of the original Svegder (Svegde) ${ }^{1}$ is found in the fifteenth chapter of the Ynglinga Saga by Sturleson. It deals with an Uppsala king's journey to the Black Sea to find Odin the Old. On the way he is enticed into a mountain by dwarfs and never returns. According to Sturleson, it was Svegder's second effort to reach Gudhem, i. e., "god-home," the home of Odin. "Once more Svegde set out to reach Gudhem. In the eastern part of Sweden (Svithiod) there is a large village by the name of Stone (Sten), where there is a rock as large as a big house. In the evening after sunset, when

$1 \mathrm{He}$ was the grandfather of Wisbur, whom we have treated above. 
Svegde was returning from the drinking-bout to his sleeping chamber, he looked at the rock and saw that a dwarf sat beneath it. Svegde and his men were very much intoxicated and ran against the rock. The dwarf stood in the door, calling to Svegde, and bade him come in, if he wished to find Odin. Svegde hastened to come inside the rock, which closed immediately, and Svegde never came back."

Of the original dramatis personae only one character (the dwarf) appears in Stagnelius's fragment. But the poet has introduced three others: Nore, a giant; Sindre, a dwarf, servant, and watchman in the employ of Nore; and Hild, Nore's daughter, who is to entice Svegder. The hero himself does not appear, but we are acquainted with everything there is to know about him. He is the fifth grandson of Fridulf, who formerly established altars to the glory of Odin, and represents the power of light. Opposed to him are the dwarfs and the giant Nore, who represent the servants of darkness. From this list of characters the main theme may be imagined without further comment.

The dwarf has just completed a chain, the making of which has been entrusted to him by the King of the Mountain, Nore. The different links of the chain furnish material for philosophical reflections on the judgments of fate. ${ }^{1}$ Nore tells the dwarf to keep the "new Gleipner" (the chain) which has been forged by the powers of revenge for destructive purposes against Odin's children. Then follows a brief history of the creation and of the original strife between the gods and the giants. Nore summons the sons of Ymer (here, the dwarfs), reveals to them their origin, and inspires in them a hope of future joy. The giants and dwarfs are brothers, and upon their altars the people were wont to worship, until Odin came and defeated the King of Materia, i. e., Ymer. All giants and dwarfs drowned in the blood of Ymer except Bergelmer, with wife, children, and slaves, who escaped. Through these the race carried on an eternal war against the powers of light.

1 Cf. Schiller's "Das Lied von der Glocke"; the different stages in the casting of the bell and the accompanying reflections represent the different stages in the growth of an individual. 
They often forged weapons of murder for man and "by means of the alluring food of gold brought them into vice and destruction." This condition continued until Fridulf's son came and established altars to the glory of the God of Light and frightened the dwarfs back into the rivers and mountains. That is, Odin was recognized as the victor, although the divine power of darkness was still worshipped.

It is hardly necessary to observe that in the introductory epic material of the fragment we have nothing but Christian ideals in the garb of Norse mythology. Odin is virtually none other than Christ himself; or better, perhaps, the personification of what we call Christian ideals. This becomes still more evident as Nore's narrative goes on. According to a "ridiculous" saga, which originated in the "sacred palm-abode of India," Odin was to allow himself to be born of an earthly woman to redeem man. And now Svegder, who believes Odin to be his ancestor, has set out for the land of palms, olives, and sycamores to visit the God who has just been born of woman. In other words, Svegder is undertaking a pilgrimage across the Baltic to the Orient, which the poet supposes to be the cradle of both the Old Norse and the Christian religions.

Then commences the real dramatic action which is very brief. Nore knows about Svegder's journey and has sent Hild to entice him. His servant, Sindre, is watching upon the top of the mountain for the approach of the victim. Sindre arrives on the scene and announces the arrival of Svegder with a band of warriors. Then Hild enters; evidently she has already laid the snare, and she sets forth how a situation of that kind must always be met. The only means for darkness to overcome light is "the haven of a maiden." A glance, a voice, will "disarm the whole power of the sun and allure the regents of the stars down from their thrones to an effeminate rest on a bed of flowers."

Here the fragment ends, and there is very little more that can be said about it. It is another illustration of a Romanticist's unsuccessful attempt to dramatize a saga theme. But this much must be said: there is a wealth of meaning hidden in the original source and it would have proved interesting to 


\section{3}

see how Stagnelius really intended to formulate the drama as a whole.

Dramatically, "Svegder" was not a success, even as far as it went; and probably could not have been, if completed. The internal meaning was more suitable for an epic than a drama, and there was not enough material in the original for a complex, well-developed plot. It was merely an episode and the hero, who is a tool of cruel fate, is practically ensnared at the beginning of the drama. There is no more to develop. Then, too, a pretentious scheme, where woman was to be the tool and unconquerable emissary of the powers of darkness, could hardly prove an agreeable dramatic topic in this case. It was based, it seems, on personal opinions which were too severe and pessimistic. 


\section{CHAPTER V}

Nicander and Beskow: with Special Reference to the Age of Transition from Norse Heathendom to

Christianity, as Reflected in the Romantic Dramas of these Two Men.

"Det går så alltid, att det gamla, torra, Skall lemma rummet åt det unga, friska." Oldur in "Runesvärdet."

There is no literary amalgamation of Romantic and viking elements during the Swedish Romantic period that makes more fascinating reading than "The Runesword and the First Knight" (Runesvärdet och den förste riddaren) by Karl August Nicander. "The Runesword," a tragedy in four acts, is written in pentameter and appeared in I82I when the author was but twenty-one years old. The freshness, the remarkable imagery, the imagination and the originality displayed in the drama won even Tegnér's hearty admiration. At first we find a pleasing variety; full descriptions of scenery and stage directions, lyrical passages, a saga in prose, a mixture of monks and warriors in the list of dramatis personae, as well as an archbishop, a king, a ghost, and a champion, presumably heathen, with the omnious name of Orm (serpent). On closer inspection we find strong dialogs, sublime monologs, a miracle, a devil disguised as a monk, and an old doubting weakling, who attributes the failure of his crops to his recent conversion. The unities are disregarded; the action covers a period of over "three hundred days," the tragedy is localized in the vicinity of Björkö and Adelsö in Sweden, but the scenes are shifted frequently, and within the same act. We can hardly speak of any unity of action, for there are too many important characters in the limelight, and Alrik, "the first knight," is too impetuous and vacillating, and his most dramatic maneuvers are determined too much by external circumstances to warrant the 
name of a strong tragic hero. Often peasants are introduced to demonstrate the prevalent division of sympathy between the old gods and the new God, and, as in Act II, sc. 2, to show admiration and faith in their leader, the nominal heathen but potential Christian Alrik. The nature-setting throughout is picturesque and impressive, never too gaudy, and the opening scene would do justice to a grand opera. Several scenes are laid at sunset or at the dead of night, amid lamps, lanterns, torches and thunder and lightning, and offset by mental disturbances in the souls of the old, confirmed pagans or the recently converted Christians. An actual or assumed intolerance and violence on the part of the monks, and the spasmodic berserkerrage of Alrik alternate with scenes of the deepest melancholy, based on an extreme Catholic system of religious thought.

There could hardly be a tragic theme more Romantic, dramatic, and inexhaustible than the conflict between a medieval Christian and a Norse heathen. Oehlenschläger had already treated the same theme in "Hakon Jarl," in I807, and in a letter to M. v. Schwerin, dated in Lund, October 4, I82I, Tegnér writes: "Several years ago I commenced a 'Blotsven,' which was to represent the severe struggle between Christianity and heathenism. A glorious theme: the decrepit Asas who stand sponsors at the baptism of the North!" 1 But Tegnér knew he was no dramatist and, according to this letter, threw both Asas and monks into the stove. Nicander, however, had better success with the theme.

At the opening of the first act, a dragon ship is sailing by in the distance, at sunset, with singing vikings upon it, and Oldur is seen in the foreground, on the shore, grinding his sword and lamenting the degeneration of the viking. Led by Peregrinus, a band of Christian catechumens arrives: Oldur refuses to respect the cross and is ordered to be bound when his son, Alrik, rushes in with drawn sword and "eagle-helmet" upon his head and rescues his aged father. In a strong and solemn dialog on a funeral mound, Alrik takes the fateful vow to slay that one of his race who first forsakes his ancestral belief. With much skill Nicander contrasts here viking deeds

1 Jubelfestupplaga, V, p. 233. 
and clash of arms with the "effeminate children-songs," "black books," and "white women's-clothes" of the monks. An old man and recent convert, Edmund, appears to protest against the new confession; all prosperity has left him since he changed his faith; he stands now as a victim of two angry divine powers; twelve nights of song and prayer have been of no avail, and his Christian daughter has become as "pale as the flowers" on his meadow. Bishop Ansgarius, who is present, points with kindness, comfort, and piety to the land above; Edmund is convinced, rather too easily, of his mistake and the crowd disperses in the darkness. Then comes one of the remarkable monologs in the tragedy. Peregrinus appears with a torch and divulges in strophes of "gloomy beauty" and demonic power his true character. He is a devil sent to earth to "destory the cross" and incite hatred between the contending factions. Then, from a Romantic brimstone atmosphere of sighs, tears, and genuinely satanic reflections the scene is shifted to Edmund's peaceful dwelling. Here the pagan Alrik takes farewell of his betrothed Hulda, Edmund's daughter, who is a super-devout Christian. After Alrik's departure, Hulda upbraids herself to her father for a "criminal" love, overemphasizes a guilt which is mere imagination in the first place, deems herself the cause of her father's misfortune, and, finally, father and daughter decide to make a pilgrimage to the holy sepulchre to win peace for their souls.

In the meantime, Peregrinus has been faithful to his satanic mission. In the beginning of the second act, a temple has been burned and the whole city barely rescued from the flames. Shortly afterwards a woman appears carrying a dead child in her arms, and we are given to understand that a monk had baptized it to death by order of the Bishop (Ansgarius). Both crimes are the work of Peregrinus, of course, and the impulsive Alrik, supported by a large group of followers, is determined to restore the religion of their forefathers. The angry populace is pacified temporarily, however, by Folke Lagman, in whom Nicander has attempted to create an ideal, though somewhat modern, type of the viking lawyer and judge.

1 Cf. C. D. af Wirsén: Lefnadsteckningar, Stockholm, 1901, p. 185. 
Folke is the embodiment of wisdom, and in clear and splendid language urges caution, deliberation, and justice. Crime cannot be cured by crime-a modern idea-is Folke's principle.

"Ju längre molnet skockar sig och svartnar,
Dess starkare blir thordön, då den kommer.

Alrik is sitting on a stone below a chapel. Ansgarius comes out and Alrik raises his sword above the Bishop, when the mother with the dead child appears, and the would-be assassin checks himself and withdraws. The woman's abusive attacks on the Bishop are repaid with kindness and a miracle takes place when Ansgarius places his hand on the child's head; the child opens his eyes and lives to the intense astonishment of both. Alrik has been a distant witness of the dramatic miracle and is deeply affected, but strangely enough our viking Hamlet rushes into Oldur's dwelling soon thereafter, determined to save the grandchildren from later conversion by immediate slaughter. Still more mysteriously he believes he can carry out the provisions of his horrible oath by such a murder. The only possible explanation for his attitude is an inner despair, akin to madness, occasioned by a full realization of his own wavering condition. He does not carry out his dastardly plan and begs his father to take back the runesword. This Oldur refuses to do, reminding him of his fatal oath.

The ten scenes of the third act prepare the way for Alrik's formal conversion and for the Thing which is to decide the fate of the Christians. The monk, Clemens, teacher of Alrik, is accosted by some heathen warriors and forced to give up his Bible. The old Norsemen are struck by the "mysterious book," easily interpret its illustrations in terms of their own religion and decide to retain the book as evidence against the Christians. In the second and third scene between Oldur and Folke, and between the father and the son, we learn something about the mental struggles of Alrik, but not enough, ${ }^{2}$ so that the hero's sudden enthusiasm for Christianity later seems un-

1 "The longer the clouds gather and darken, the more violent is the thunder when it comes." See Sc. 3. Nicander: Samlade arbeten. Tredje upplagan. Senare delen, pp. 347-48. All references are to this edition.

2 Cf. Wirsén, as above, p. 187. 
natural, even if he has never been a very strong heathen. The fourth scene shows the danger of the Christian missionaries, and Clemens urges Ansgarius, of course in vain, to flee before the coming Thing is held. In scene 7 we see Clemens and Alrik on a "dark night" zealously studying the Bible in Edmund's desolated home at Adelsö. Edmund himself comes back from his pilgrimage with a message from his dying daughter, Alrik rushes out, and in his anguish is about to kill himself when Hulda's ghost appears and entreats her former lover to be baptized. At sunrise Alrik is a Christian convert.

Tegnér liked the last act best. ${ }^{1}$ It has more of the necessary dramatic unity and concentration than the remainder of the tragedy, and the modern biographer Wirsén rightly characterizes the opening farewell monolog, where Alrik buries his viking armor and sword, as one of "almost sublime power."2 Peregrinus has been a silent spectator at the burial of Alrik's weapons. He urges Orm, who is of Alrik's stature, to dig up and don the armor and, thus disguised as Alrik, and prompted by Peregrinus, to fight against the Christians. Orm, who has an almost humorous turn of mind, is ready to do anything, provided he does not have to think. ${ }^{3}$ The next few scenes take place in a chapel after midnight, when Alrik is baptized by Ansgarius, gets other armor from the Bishop, and becomes a knight of the cross. Finally, in the last three scenes we have the Thing in the open air. King Olof is present and testimonies are heard. All atrocities attributed to the Christians point to one man, but he has escaped, a rather cowardly and unnecessary trick for a devil to play, for the one perpetrator is, of course, Peregrinus. Upon the suggestion of a wise peasant, the question of guilt is to be decided in mortal combat between two representatives. Naturally Alrik becomes the champion of the Christians, and Orm, with Alrik's armor and runesword, of the heathen and the gods of Valhalla. In the encounter Orm is killed, Oldur picks up the sword, discovers

1 Cf. letter to M. v. Schwerin of April I, 1821. Jubelfestupplaga, V, p. 223.

2 Lefnadsteckningar, p. 188.

3 Sc. 2, p. 4 ig. 
the adversary to be his son Alrik, pierces himself and is about to rush at Alrik, when the latter announces that he has already been fataly wounded; the runesword had performed its mission.

The sources of this plot are not very extensive. Wirsén points out that we must not expect to find local color or believe that "The Runesword" gives any pronounced Kulturbild. ${ }^{1}$ Nicander's studies or knowledge of human life cannot have been very comprehensive at his age, and this may account for the lack of firmness in some characters. But we are wrong to suppose that there is no approximation to historical truth in "The Runesword." Nicander localizes his tragedy at Björkö, puts the time at "about 850," and introduces King Olof and Archbishop Ansgarius (Anskar). Now both of these are actual historical personages; they lived "about 850 " on or in the vicinity of the island of Björkö, which is situated about eighteen English miles west of Stockholm; and many other features of the tragedy have, apparently, a more definite historical setting than is ordinarily supposed. The historical "Apostle of the North" remained two winters at Birka, a prominent port on Björkö in Lake Mälar, on his first missionary trip to Germany in 83I A. D., " in order to report progress to the emperor."' "Anskar, whose personal interest in the mission (i. e., in Sweden) still continued, came again to Sweden in $848 \mathrm{~A}$. D., in the time of a king called Olof, and remained for about the same time as before." 3 This was two years, which would put the end of his second stay at "about 850," the date set for the drama. Edmund's complaint in Act I, sc. 4, that the old gods were probably angry with him for being converted, seems to be more than a mere brainstorm, historically, and the same is true of the introduction of King Eric's image in Act II, scenes I and 2. The Bishop of Salisbury, in his recent lectures on "The National Church in Sweden," writes, with respect to Anskar's second visit to Sweden: "Complaint was made that the (heathen) gods were angry because their

1 Lefnadsteckningar, p. 191 .

2 John Wordsworth, Bishop of Salisbury, The National Church of Sweden (The Hale Lectures, 1910), London and Oxford, England, and Milwaukee, U. S. A., I9II, p. 52.

3 Ibid., p. 54. 
sacrifices were neglected; and an enthusiast came forward to announce a vision which he had received from the gods forbidding the people to deify their late king, Eric."1 And there is historical justification for the Thing in the last act of "The Runesword," for Bishop Wordsworth goes on to say: "On Anskar's (second) arrival the king and his nobles determined to ask counsel of the gods as to whether the mission should be encouraged or not. ... On this occasion it (the consultation, by lot, with the gods,) was favorable to Anskar. After this the question was put before two public assemblies, probably one at Birka and one at Uppsala." 2 The historical Anskar was as saintly and fearless as Nicander depicts him and we may well imagine him in such a danger as the monk Clemens describes in Act III, scenes 4-5, even in Sweden. Anskar had to flee for his life in 845, when the Northmen, under King Eric, plundered Hamburg. That the old vikings were especially fond of telling stories, as Oldur does to his grandchildren in Act II, sc. 7 , is historically correct. That pilgrimages to the holy land were taken, as in the case of Edmund and his daughter, is mentioned in the saga literature by Snorre Sturleson, such as the saga of Sigurd Jorsalafarare. Nicander did well to localize his drama on Björkö; such grave-mounds as are mentioned in it, and on one of which Alrik takes his fatal vow, are said to be extremely numerous on Björkö to this day.

It is tolerably clear that Nicander had already studied Old Norse history to a considerable extent when he wrote "The Runesword," but it is difficult to name his actual sources. We may say that all the sagas which Nicander had read contributed to the setting of the tragedy, and out of the composite material the poet created his types, chose his environment, and invented his plot. As far as I know, no other characters in "The Runesword" have definite historical prototypes than those mentioned. Beyond these we have to accept the author's words in the dedication:

1 Ibid., p. 55 .

2 Ibid., p. 55. 
Ur inga böcker jag mitt ämne hämtat, All verdslig sanning har jag här forsakat Och endast sökt det andeligen sanna. ${ }^{1}$

One might expect from this dedication, which commences with the beginning of St. John's Gospel and is dedicated to Almighty God himself, that the tragedy was to show the victory of Christianity over paganism. Nicander says: "But the word of the Lord was triumphant." ${ }^{2}$ In the development of his drama, however, his sympathy for the rough and ready Norseman is so striking as to become a mild glorification of vikingism, and, to my mind, he succeeds best in the portrayal of the viking element. And that a Scandinavian youth of twenty-one should be thus inclined is natural. The tone of "The Runesword" becomes almost didactic; the reader must feel the underlying plea for tolerance toward the old religion of the Northmen. Nicander seems to say-and it could not be wholly unconscious-that religion, per se, is deeper than either Christianity or Valhalla worship. Consequently the main difference was not so large, after all, and was largely one of interpretation. To the heathen warrior in Act III, sc. I, many illustrations in Clemens's Bible fit surprisingly well into his own religious conceptions. He opens the book and exclaims, in part:

Här står ju Brage sjelf med gyllne harpan;

Der Thor, med portarna vid Jotunhem

På ryggen; se, der har han Midgårdsormen,

Vill slita upp dess gap med gudastyrka.

$\mathrm{Nu}$ kommer Valhalls sal, så hög och präktig;

Der ser man ljusastakan stå på bordet

Med gyllne armar jemte mjödets kärl,

Och Oden sjelf, i djupa tankar sänkt,

I gullskrud och med bröstlapp, höljd af perlor, . . . ${ }^{3}$

1 "I have not taken my theme from any books, I have renounced all worldly truth here, and only sought the spiritually true."

2 See dedication, p. 294.

3 "Why here stands Brage himself with the golden harp: there Thor with the gates of Jotunheim upon his back; behold, there he has the Midgard-Serpent, and is about to tear open his jaws with the strength of a god. Now comes the hall of Valhalla, so high and splendid: there one sees the candlestick stand on the table with golden arms, together with the vessel for the mead, and Odin himself in deep thought in golden garments, and with breast-protector, adorned with pearls." See p. 376 . 
And further:

Se Balder, hvar han ligger blek och död, Och Nanna står vid båren stum och gråter, Mig tyckes verlden död; så tyst och kalt Är allt omkring den fallna gudasonen. ${ }^{1}$

The last scene has a broad-minded tone of equality and reconciliation which may be taken as the teaching of the tragedy. With genuine sympathy for ancestral worship, expressed in a beautiful language with a poetico-Romantic conception of spirits meeting after death, King Olof voices the sentiments of the poet in these verses:

Jag reder Far och Son två skilda högar:

Planterar korset uppå Alriks graf;

Jag detta svärd vill på den andra sätta.

Helt nära de bredvid hvarandra hvile,

Att deras vålnader $\mathrm{i}$ stjernenatten

Må, sittande på hvar sin egen hög,

Hvarandra handen räcka till försoning. ${ }^{2}$

It is important to observe the style and dramatic technic of "The Runesword." The meter is almost perfect, for Nicander had a good feeling for form, and the language is clear and simple. Even ghost-scenes are objectively portrayed. Rime is frequently employed-a characteristic which is incompatible with the Old Norse theme $\mathrm{e}^{3}$ - and the style betokens the mind of a genius. The tragedy is rather long to be put on the stage; in its original form, in the third edition of Nicander's works, it covers I59 octavo pages of actual drama, and a condensation would, I believe, spoil its beauty. As far as I have been able to determine, no attempt has been made to play "The Rune-

1 " Behold Balder, where he lies pale and dead, and Nanna stands silent beside the bier and weeps. The world seemeth dead to me: so quiet and so cold is everything around the fallen son of god " (meaning to the viking, son of $a$ god, or any god).

2 "I will prepare two separate mounds for father and son (Oldur and Alrik); plant the cross upon Alrik's grave; and place this sword upon the other. May they rest right close to one another so that their ghosts, sitting upon their respective mounds in the starlit night, may extend their hands to one another for reconciliation."

3 Cf. Wirsén : Lefnadsteckningar, p. Igr. 
sword," and one reason must be its lack of sufficient concentration. But it has numerous genuinely dramatic parts, plenty of action, and with its setting and tragic effects should furnish an excellent basis for a grand opera. Poor motivation prevents a strongly knit dramatic structure of the work as a whole. Oldur's hatred of the monks is motivated, in part, by personal reasons, and he is, therefore, not attached to paganism with strong enough bonds. That Alrik and his betrothed should have to part seems absurd, even to an extreme ascetic Christian. Both contemporary ${ }^{1}$ and later ${ }^{1}$ critics have applied the Shakesperian standard of motivation to Alrik in "The Runesword" with much severity. And rightly so, if we have the right to apply such standards at all, in this case. The conversion of the new Hamlet is determined by the appearance of a real ghost, and his death brought about by what seems almost like mere chance, and in reality is the work of Peregrinus. But, for what Nicander undoubtedly intended, the motivation is better than one might suppose at first. After Alrik's fatal vow, which he makes with a tragic impulsiveness, the vow takes care of itself and the real hero after that is the runesword itself. We have here a kind of fate-tragedy, half Greek and half Wernerian, where an incomprehensible something guides a mechanical instrument until it has concluded its tragic mission. And then, also, as Wirsén points out, ${ }^{2}$ the old sagas often attributed an independent, mysterious power to swords. From a strictly dramatic viewpoint, the interference of supernatural charac-

1 I refer in particular to the enthusiastic recension of the tragedy in Svensk Litteratur-Tidning for 1821 , Nos. 17 and 18 . This review, now known to have been written by Palmblad, was formerly attributed to Atterbom and is printed in Atterbom: Literära karakteristiker (Vol. 7 of Samlade skrifter, Örebro, 1870), pp. 282ff. By the modern critic I refer to Wirsén: Cf. Lefnadsteckningar, pp. 189-90. In the above review, Palmblad criticizes the whole invention of Peregrinus, whom he calls a "stupid devil," as interfering with the free will and individuality of the hero. Palmblad also queries whether Nicander should have allowed the monks to attack Oldur, for the missionaries were in enough danger as it was. Again Palmblad does not believe that Anskar had an armor, for he was already bishop when he came to Sweden. Cf. review, p. 29I. Yet the reviewer admits he had not read this tragedy without tears, p. 286. Palmblad mentions Oldur's personal reasons for his hatred of the monks.

2 Lefnadsteckningar, p. 189. 
ters, however, such as the weak but interesting devil Peregrinus, is, I presume, a technical fault.

But we have to analyze "The Runesword" as it is, and not as unrelenting critics think it ought to be. We are not dealing with a stereotyped Shakesperian drama but with a lyrico-Romantic tragedy, with epic breadth and examples of some really good poetry. "The Runesword" is a Romantic version of a composite saga, where the two important constituents are the Romantic and the saga element. It remains for us to examine these two constituents.

Wirsén declares that Nicander did not belong to the New School ; ${ }^{1}$ Tegnér says he did, ${ }^{2}$ and that he had many of the " bad habits and oddities" of the New Movement. It all depends on the meaning one attaches to the phrase "New School." If by the New School we mean the more narrow, militant circle of the Fosforists, then Wirsen is right; for Nicander was not a formally enrolled member of any school when "The Runesword" was written. But as soon as we penetrate below the surface of the matter we shall have to stamp " The Runesword" as a Romantic product, even in the restricted sense. Nor do I base the claim upon the fact that Nicander contributed to the Fosforistic organ Poetisk Kalender. ${ }^{3}$ Wirsén himself has to admit at least temporary "influences of a new-Romantic conception," and calls Edmund "a complete new-Romantic creation, unintelligible in his fantasticalness, his weakness, his insanity, and unfortunately, also, in his piety.", "But," Wirsén goes on to say, "such a disease was a part of the new-Romantic temper," and then ascribes this characteristic of the "melodramatic" and "medieval" portrayal of "hoary antiquity" to the influence of Fouqué. Tegnér, in his important letter to

1 Ibid., p. 193.

2 Letter to M. v. Schwerin of April I, I821. Jubelfestupplaga, V, p. 222.

3 Wirsén attributes the "misconception" of regarding Nicander as a member of the New School to the fact that he contributed a poem to Poetisk Kalender. The poem in question was "Song of Loyalty" (TrohetsSång), inserted in the Kolender for 1820, p. 21 I. Cf. Lefnadsteckningar, p. 193, and note.

4 Ibid., p. 193.

5 Ibid., p. 189. 
Nicander himself, ${ }^{1}$ criticises " die romantische Breite," which represented an epic rather than an action, prevented concentration, and was a mirror rather than a focus of history. Then, too, he objected to the mysticism-in this case synonymous with the supernatural-which, with its "misty and holloweyed forms," had always been repulsive to him. And, indeed, the tragedy has an extensive Romantic pot-pourri of miracles, medieval conversions, ghosts, tears, forebodings, longing, superstition, feeling, "indescribable anxiety," and Stimmungen. Hulda is as much of a Romantic product as her father, only worse. With her, religion has become a fatal disease, and her mystic reflections on the cross and the Holy Virgin remind one of Brentano's Catholicizing "Rosenkranz." There is no Fosforistic obscurantism in "The Runesword," but many words and expressions remind one of the New School; such as: liljeklockan (the lily-clock) ; evighetens rosenverld (the rose-world of eternity) ; Guds renhets sinnebild (the symbol of God's purity); rosenbindel (rose-bandage); Gudars silverport (the silver-gate of the gods); evighetens rosenband (the rose-band of eternity); silfverglans (silver-luster); silfverkulle (silver-hillock); and liljekinder (lily-cheeks). ${ }^{2}$ The night and the moon ${ }^{3}$ play a prominent rôle in "The Runesword" and envelop the action in a semi-fantastic, Romantic haze à la Tieck. Edmund says: "The time of my wanderings is at night, when darkness comes from the sea, and spreads its mantle over the island, and conceals my misery." 4 Nicander employs at times a Southern verse-form, the ottave-rime, in "The Runesword," another mechanical feature common to the program-makers of the new movement. And lastly, the fact itself that the tragedy is poetical and lyrical rather than strictly dramatic, points towards a new-Romantic relationship.

I have already stated ${ }^{5}$ that Nicander was most successful in the portrayal of the saga element, and this because the drama-

1 Letter of February 9, I827. Jubelfestupplaga, VI, pp. 68-7 I.

2 Cf. Arbeten, pp. 313, 320, 323, 324, 350, 354, 406, and 408, respectively.

3 Cf. Arbeten, pp. 321, 323, 324, 325, 328, 329, 374, 409, and 410.

4 Act I, sc. 7 .

$5 \mathrm{Cf}$. above in this chapter, p. $15 \mathrm{I}$. 
tist, better than any other, felt the tragic sympathy which should lie with the heathen in this case. The result is that Alrik is best as a pagan, or when he shows viking tendencies, and his father Oldur Silverbeard, is the most masterfully drawn character. But the viking characteristics, in either case, are of a merely general type and Oldur has but few individual traits. Oldur is an idealized composite image of the saga age, as Nicander imagined it from his necessarily limited reading. The "beautiful viking life," "a song upon the sea," the "faithful sword," and the conception that a "life full of exploits is more beautiful than death," enter into the program of any heathen pirate, and so it does into Oldur's. ${ }^{1}$ As a youth he was a man of action who could oppose ten ${ }^{2}$ in combat, and who in his old age regrets that his sword is rusty with old blood and can draw no new. Oldur evinces the traditional Northern defiance of death: "Slay me," he tells Peregrinus in Act I, scene 2, "then you can seat yourself on my body and sing the song of ravens and plunder unhampered." Throughout the drama he remains the respected, inflexible champion of the old Scandinavian gods and at the end dies on the runesword by his own hand, as a viking should if not killed in battle. "It is better to die in work or action than to go to sleep on the death-bed under a roof," exclaims Oldur in Act II, sc. 2. For him the age of combat and victory, when the song and "the magic staff of the saga," refreshed the warrior for new exploits, was the glorious period. ${ }^{3}$. In his invocation to his son in Act I, sc. 3, there comes a plea for the "clang of swords" at the funeral-mounds of his forefathers, for the "saga traditions," for the "godlike" unity of will and power, deed and council in life, and for the inheritance of manliness and the "golden runes of Odin." Again, in Act II, sc. 8, he advises Alrik: "but above all, tread the righteous path of the gods and observe the wise judgments of the norns." Oldur is a man of experience, not only in

1 Cf. Act I, sc. I.

2 Cf. Act I, sc. 2.

$3 \mathrm{Cf}$. Act IV, sc. 9. The combination of song and battle is also represented by the First Peasant in Act IV, sc. 7. He says: "A blow upon the shield and a grip about the sword produce a glorious harmony with the song of the skald; they give weight and power to what is spoken." 
deeds, which might be true of any Norseman, but also in higher culture. He urges Folke, Act II, sc. 2, to give him the captured Christian Bible, for he claims a good knowledge of the "signs of the runes and other symbols." $\mathrm{He}$ is a lover of freedom -nothing could be more true of the pagan sea-rovers- and in the same scene (Act II, sc. 2) he says to Folke: "We must act as free men." Again at the end of the same dialog, he boldly and resolutely expresses preference for immediate action, for "war with the tongue is not the art of the Sviars (Swedes)." The old saga-heroes, in their escapades, were, of course, candid and fearless, often horribly so, and were seldom touched by the ordinary phenomena of life. Such is Oldur, and yet he rends his clothes (Act II, sc. 8) when Alrik is about to murder his grandchildren and justly exclaims: "Oh, woe, what horror! My son a wolf, my house a den of murders." In other words, there is a trace of sympathy for the defenseless kinsman, though the nature of the drama excludes a wellrounded picture of viking loyalty among kindred folk. Neither are there any adventurous dealings with women, in "The Runesword," showing the traditional Norse respect for and protection of, the weaker sex: for, the real representative Oldur is only a retired viking, too old to engage in a Brautfahrt. He is, like Götz v. Berlichingen, the victim of an advancing civilization for which he has the greatest contempt, but, unlike Götz, is too old to wage war against the new ideas. But the viking sturdiness, wisdom and brevity of speech still remain. His language is often figurative, always forceful. Compare, for instance, Oldur's appeal to the multitude, which Nicander means to be typical:

Lång sömnen var: Tid är att vakna, Männer!

Mig tyckes se, hur stridens unga örn

Sin starka ram kring edra hjertan spänner,

Och modet reser sig som vårens björn.

Upp! reten den mot frihetens ovänner,

Som kommit hit från verldens södra hörn.

(Act II, sc. 2) ${ }^{1}$

1 "The sleep was long: It is time to awake, men! Methinks I see how the young eagle of combat embraces your hearts with its strong claw and courage springs up like the bear in spring. Up! rouse him against the 
Further, Oldur, true to Old Norse convictions, believes in the divine sanction and guidance of warriors on the battle-field. In this same scene he incites his heroes to action by these words: "You still have sword, helmet and shield; All-father himself goes with you to battle. Illusion shall yield. The eye of Odin radiates light and truth from on high." Storm and the sea are Oldur's elements ; ${ }^{1}$ and last, but not least, for our purpose, Oldur is a Romantic personification of loyalty to fatherland-traditions and enthusiasm for the saga age. For him the traditions of the past are sacred; he tells his grandchild:

Ett säger jag: hvad som af ålder varit, Är heligt, barn! må ingen gäcka det!",2

None of the gruesome murder, plunder, or burning, attributed to the viking marauders, is perpetrated in "The Runesword" by the pagans. The nearest we have to it is that powerful scene (II, 8) between Alrik, Oldur, and the grandchildren. Thore is somewhat unnatural, it seems to me; though but a child, he has the same utter disdain for death as a veteran fighter. He would willingly die, provided the fatal blow is not made in wrath; he is willing to die in combat but not to be butchered. In this scene, however, Alrik becomes, potentially, a wild and cruel berserk and champion of the old religion; he would slay the youngsters while they are still able to enumerate the old gods and because "innocent blood is agreeable to the Asas." “To-night I am your true image," he ejaculates to his father, "I want blood, and in that the wolf-ancestry of the wolf is recognized." 3 He draws his sword and addresses his young nephews :

Knäböjen, barn! nu vandren I till Oden.

Jag ser, ni bäfven ej för sista resan.

Friskt mod, ren blick ännu I dödens timma,

enemies of freedom who have come hither from the Southern corner of the world."

1 Cf. Oldur's words to his son in Act III, sc. 3 : "Wind was my delight in my younger days."

2 Act II, sc. 7. "One thing I say: whatever has existed in the past is sacred, child! May no one ridicule it!"

3 See edition, as in note 1, p. 147, p. 369. 
Och upprätt hufvud, karlafärg på kinden:

Det är en Svears sed att så se ut.

Vak upp i Valhall, öppna silfverporten!

Två gudabarn dig gästa, store Oden!1

Critics have assumed an influence of Fouqué and Oehlenschläger on "The Runesword." ${ }^{2}$ Fouqué was much admired in Uppsala about 1820, and his themes from Norse mythology were undoubtedly well known. "Sintram und seine Gefährten," based on a Northern saga, had appeared in I8I4;" "Die Fahrten Thiodulfs des Isländers," in I8I5; and "Sigurd der Schlangentödter" as early as I808. Several translations from Fouque had been made also during the second decade of the century. I find in Sondén's edition of "Svenska vitterheten",3 by Hammarskjöld that some of Fouqué's novels were translated into Swedish in $18 \mathrm{I} 6$ by a B. J. Törneblad, "Undine" in I8I9, and "Eginhard und Emma" by G. Schentz in I8I7. There is no doubt, then, that Fouque was studied in Sweden about this time. Atterbom and Livijn knew him well. But his direct influence on Nicander cannot be determined with any certainty and was probably only of a general character. The Gothic tendencies had already a firm foothold in Sweden, and so Fouque could, in this particular, at the most, only intensify an impulse which already existed. But the influence of medievalism is probable. There are some striking similarities also in the internal plan and conceptions between "The Runesword" and "Thiodulf des Isländers." The setting in both cases is at the dawn of Christianity, the hero Thiodulf wavers between Christ and Odin much as Alrik does, and in the end is baptized and becomes a Christian. Then we have also the same broadminded fundamentals in Fouqué's novel as in Nicander's trag-

1 "Kneel, children. Now you travel to Odin. I see that you do not fear the last journey. Fresh courage, clear vision, even in the moment of death, and head upright, with manly color on your cheeks; it is the custom of Svears to have that expression. Wake up in Valhalla, open the silvergate! Two god-like children will be your guests, great Odin!"

2 See above, p. 13. Wirsén: Lefnadsteckningar, p. 190. Cf. also Henrik Schück och Karl Warburg: Illustrerad svensk-litteraturhistoria, II, p. 757.

3 See list of Bibliography. 
edy: that the difference between the two contending religions was one merely of interpretation and that, as such, the two might well exist side by side. Both are a plea for sympathy with the saga-period, its religion, and people.

More plausible, to me, is the influence of Oehlenschläger on "The Runesword." Oehlenschläger had more of the viking in him than Nicander and had already treated the same theme dramatically, at least twice. "Hakon Jarl" (I805) and "Palnatoke," written in Paris in 1807 and published and played two years later, both depict the struggle between Norse paganism and Christianity, and the heroes are, in both cases, champions of the gods of Valhalla. Hakon and Palnatoke both die, like Alrik, by the hand of another, and in "Palnatoke" as in "The Runesword," fate guiding another's hand kills the hero. Hakon dies at his own request like a viking, pierced by Karker's spear, and, similarly, Oldur in "The Runesword" dies voluntarily, though by his own hand. "Hakon Jarl" has a treacherous emissary, Thorer, who corresponds somewhat to the satanic emissary Peregrinus in "The Runesword." In the last part of the drama Hakon Jarl is as zealous a champion of the Old Norse ideals and religion as Oldur, and there is a supernatural element in both works.. In "Hakon Jarl" Auden (Odin) himself appears and explains his cult to Olof Tryggvason, showing a difference of interpretation of religion-as Nicander proposed to show-due to climatic conditions. ${ }^{1}$ The ideal heathen, as pictured in "Palnatoke," appears again in Oldur; he means what he says and never retracts a word. In "Palnatoke" we have a Christian bishop Popo who speaks of a miracle; in "The Runesword" we have Bishop Anskar who performs one.

It will be in order here to mention another, more definite phase of Nicander's interest in the saga element. On the 3oth of April, I822, Nicander was elected to membership in the Gothic Förbund. He proved to be of more than usually good

1 The influence of Montesquieu and also of Rousseau is more marked in the Danish dramatist than in Nicander. Snorre Sturleson mentions in the saga of Olof Tryggvason, Chap. $7 \mathrm{I}$, that Odin visited Olof, but there is no mention made of any religious discussion. 
Gothic material and seemed to be the only one of its members who took the prescribed inauguration paper seriously. Many of the "Goths" were utterly ignorant of Old Norse affairsas is shown in the superficial characterizations of their ancestral namesakes-but Nicander, as Norna-Gest in the Gothic Society, gave a beautiful and intelligent biography of the semihistorical skald and warrior Norna-Gest, especially as guest (Gest) of Olof Tryggvason. ${ }^{1}$ The biography is very enthusiastic and effective, simple yet rhetorical, solemn and dignified, sane and in excellent language. Here, then, Nicander took an exhaustive interest in a definite saga, that of Norna-Gest.

The Norna-Gest Saga was the inspiration also of one of Nicander's early poems, called "Norna-Gest." It is divided into three parts: "The Arrival of the Guest" (Gästen kommer); "The Fighting of the Drunkards in the Hall" (De drucknas strid i salen); and "The Power of the Harp" (Harpans makt). Only the setting is taken from the original and the development of the theme is almost wholly an invention of the poet. But there is an echo of saga-historical truth in the first part. The last line of every stanza is: "Den gamle lyster hvila" (the old man desires to rest); and the original saga tells us that the king (Olof), on the first night, retired immediately after the arrival of the skald. The action of the last two parts is supposed to take place while the king is sleeping; the poet imagines Norna-Gest pacifying the fighting drunkards by playing his harp.

Nicander wrote many poems in a Gothic style, though not

1 Cf. Hjärne: Götiska förbundet, pp. r 39 ff., where Nicander's paper is quoted in full. According to the saga, Norna-Gest (Guest-of-the-Norns) was early visited by the norns, the last one of which jealously prophesied that he should not live longer than until the light of his cradle had burned down. The light was then extinguished by the more friendly, oldest norn and given to the mother for safe-keeping. Later Norna-Gest hid it in his harp and came at an advanced age to the court of Olof Tryggvason. Here he sings of his deeds and of Sigurd and Brynhilda, and one day takes out the faded taper, lights it, and when it has burned down, dies. Cf. Sogupattr af Norna-Gesti, in Fornaldar Sögur Nordrlanda. Kaupmannahöfn, 1829. Fyrsta Bindi, pp. 3II-342. Chapters II and 12 deal with the youth and death of Norna-Gest. His death occurred at the age of "three hundred winters" (300 vetra). 
always based on any one saga, and generally wrote them well. A splendid collection of sixteen national lyrics by Nicander, called "The Runes" (Runorna), ${ }^{1}$ was read with much commendation in the Gothic Society 1823-1824. Many of these have a general coloring and a sprinkling of names from the Edda-literature. For the benefit of the ordinary reader, Nicander himself refers in a number of appended notes ${ }^{2}$ to some of the specific sources employed. It appears upon closer examination and verification that Nicander often went to the Fornaldar Sögur and to Sturleson's Ynglinga Saga (Heimskringla) for his motifs. In the conversion of Arnliot Gellina ${ }^{3}$ in the "rune" of the same name, which is taken from the Olof Haraldson Saga (Chap. 227) by Sturleson, the poet follows the original with unusual historical accuracy. In others, Nicander modifies the saga, or uses only a small part of it, to suit his fancy. "Reminiscence of Iceland" (Islands minne), on which Nicander has only a single historical note but no exact reference, is also taken from Sturleson's Heimskringla, chapters $43-47$. It is based on the fate of Olof Wood-carver (Olof Trätälja), the last of the Ynglinga kings in Sweden and father of the Norwegian line of kings of the same dynasty. Now, according to the saga, (Chap. 47), King Olof was not zealous in sacrificing to the gods; the native Sviars did not like this, they believed him, therefore, responsible for the temporary famine, in reality due to over-population, captured him and burned him. Nicander makes Olof say: "I was burned in flames on account of my piety, much have I suffered, little am I known."4 Although the poetic embellishments are Nicander's own invention, the motif for "Hjalmar's Bride" (Hjalmars brud) is taken from the last part of Chap. 5 of the Hervarar Saga, ${ }^{5}$ and deals in

1 Cf. above, Chapter III, p. II3, note I.

2 Samlade arbeten, Förra delen. Tredje upplagan, pp. $238 \mathrm{ff}$.

3 Ibid., pp. $218 \mathrm{ff}$.

4 Ibid., p. 216.

5 Ibid., pp. 209 and 238. Cf. the following passages from Fornaldar Sögur, Fyrsta Bindi, p. 429: “ pessu naest tók Oddr Hjálmar, ok bar hann á skip út, ok flutti heim til Svipjoðar, segjande pessi tiðendi konungi ok dóttur hans; fèkk henni svâ mikels fall Hjálmars, at hun sprakk pegar af harmi, ok voru pau Hjálmar i einn haug laginn, ok drukkit erfi eptir pau." After Hjalmar had been fatally wounded, he commissioned Oddr to convey his last greetings to his betrothed Ingeborg, the king's daughter. 
beautiful poetry with the betrothed maiden's fatal grief at seeing her lover's dead body. The Romantic idea of meeting her lover in death is also present. One "rune" is suggested by the above-mentioned Norna-Gest Saga and bears the title "Norna-Gest as a Young Man" (Norna-Gest som yngling). It is an autobiographical reflection on the poet's calling, reward, and death. For his powerful and didactic "rune"-preaching fearlessness and patriotism-on that ideal Norse spokesman of the law Lagman Thorgny, Nicander mentions Sturleson as his authority in the first stanza. " Bjarkamal" is a didactic application of an incident in the Sorle Saga. ${ }^{2}$ Hogne, a Swede, and Sorle, a Norwegian, are engaged in mortal combat. Neither will give in. Sorle in a ditch, disarmed, promises to lie still until Hogne, who has thrown away his sword temporarily, gets his weapon to slay his adversary. This extreme courage moves Hogne; they extend the hand of friendship, for unity gives strength, and thus, instead of one defeating the other, they win each other over. The original saga tells (Chap. 26) how they later married each the other's sister.

In a letter to C. P. Hagberg, dated December $30,1824,{ }^{3}$ Tegnér expressed the opinion that "The Runes" were of sufficient value to be considered by the Swedish Academy in the award of the Lundblad prize. Tegnér anticipated the result of the contest, however, by entertaining the conviction that the Academy had a prejudice against Nicander for not living up to his reputation, or even Tegnér's expectations. ${ }^{4}$ Nicander re-

$1 \mathrm{Cf}$. as in note 2 on preceding page, p. 202.

Ljud sång! om Thorgny Lagman väl;

Om riket var han mån.

Han var en man till kropp och själ,

Det säger Sturleson.

Cf. Olof Haraldson Saga, Chap. 79-81.

2 Cf. Sörla Saga Sterka, Chap. 25, in Fornaldar Sögur, pridja Bind. Kaupmannahöfn, 1830 , pp. 408ff. For Nicander's poem, cf. as in note 2 on preceding page, p. 228, and note on the same, p. 240.

3 Jubelfestupplaga, V, pp. 4I I-I 2.

4 Tegnér set great hopes on "The Runesword." He writes, April I, 1821 (see Jubelfestupplaga, V, p. 223), that it was "without exception the most ingenious tragedy we have in Swedish up to the present time." As a dramatist, however, Nicander never equalled his youthful production. 
deemed himself somewhat, however, in 1825 , when he was awarded the Academy's second prize for his "Gothic" poem "The Feeling of Patriotism" (Fosterlandskänslan), and captured the highest award for "Tasso's Death" (Tassos död) in I826.

From the year 1820 dates the conception of another lyricoRomantic mingling of medievalism and a viking element; "Hildegard" by Bernhard v. Beskow. "Hildegard," which is a five-act tragedy in blank verse, appeared in 1836 in Part I of "Dramatiska studier." The author, who had traveled extensively in Europe and met most of the famous literary men of the day, dedicates his "Studies"-and this is significantto the "master" Ludwig Tieck to recall "dear memories" of Dresden days. Beskow was susceptible to all literary impulses and influences of great men, whether of this or that school, was a mediator between the Old School and the New in Sweden, and later in life was virtually, as secretary, the Swedish Academy personified. And so, the appearance of "Hildegard," with the accompanying dedication, seventeen years after he had met Tieck, must be interpreted as an unusual tribute to a Romantic "master."

The direct impulse for his drama, however, according to the author, ${ }^{1}$ was not Tieck but the consecration of a nun in Rome in 1820 , at which Beskow was present. If we add to this incident Beskow's youthful enthusiasm for saga literature, we can easily imagine the setting in "Hildegard." And that there was an enthusiasm for the saga and Swedish history is morally certain, according to Beskow's own testimony. In his "Reminiscences" (Lefnadsminnen) ${ }^{2}$ we have the following conclu-

But the continued popularity of "The Runesword," it must be remarked, can scarcely be questioned. It was translated into French by LéuozonLeduc, Paris, 1846, and into Finnish, 1855. Nicander's poems have gone through several editions in Sweden and many have been translated into foreign tongues. See Wirsén's biography of Nicander. It was due largely to the friendship of Nicander and Longfellow, contracted in Rome, 1827, that the latter's interest in Scandinavian literature was intensified.

1 See "Dramatiska studier," första delen, p. 72. In the same place Beskow acknowledges his indebtedness for a few opening stanzas to a legend by Schack Staffeldt.

2 Completed 1857. Printed in Stockholm, 1870. See p. 49. 
sive autobiographical reference to studies at Uppsala in I8I I :

"Strangely enough I had then (in I8II) 1 only two favorite subjects which interested me: mythology and Swedish history. Stridberg's mythology I had read through a countless number of times, so that I knew it. by heart. Dalin's, Lagerbring's, and any other history I could get hold of, I devoured with insatiable hunger. Also Björner's "Tales of Combat" (Kämpadater), the Wilkina Saga, and any other sagas that were on hand. These I borrowed from the gardener's library and often read them at night; for sagas were held in but little esteem in any environment at the time and were considered suitable only for women."

The Goths, in the meantime, had been attracted by Beskow's "Gothic" qualities and he was elected to membership in the Society at the same time as Nicander, April 30, I822.

"Hildegard" is much in the same style as "The Runesword" and must have been influenced by it. The Norse element is imbedded in a rigid Catholicism, the time is the sunset of Norse paganism, and the plan of the tragedy gives, to a certain extent, a contrast and conflict between Christianity and Scandinavian heathenism. The main theme-which does not concern us as much as that of "The Runesword"-is similar to the theme in "Atala" by Chateaubriand: the daughter Hildegard is the victim of a vow made by her Catholic parents to atone for a previous crime, and discovers too late that she is released from the stipulations of the vow. The motivation, as in Nicander's tragedy, is often inadequate. The sympathy for the viking religion is that of Nicander, Oehlenschläger, and Fouqué: it is tolerated side by side with Christianity. "Hildegard" has never been played, to my knowledge, but the tragedy furnishes good, dramatic reading, with beautiful poetic passages. Though more simple and concentrated, the drama, as a whole, does not come up to the high standard set by "The Runesword." Since the unities are observed, there is less variety and action than in "The Runesword."

1 Beskow, speaking later in the same paragraph about his religious emotions at the time, says: "This may seem somewhat unusual for a youth of fifteen." Now, Beskow was born in 1796 , which would put the date of this interest in $18 \mathrm{Ir}$.

2 Beskow was much more of a dramatist than Nicander but, somehow, 
The nature of the saga element in "Hildegard" is somewhat the same as in "The Runesword" but it has a stronger semblance of local color. This is due, first, to more explicit references to and descriptions of, viking characteristics and customs; secondly, to numerous references to specific characters and incidents in the sagas and early Scandinavian history; thirdly, to a comprehensive use of terms from Norse mythology. For instance, to illustrate these in order, in Act II, sc. 2, we find it was the custom in the race of Starkad and Storwirk to take a bride by force or robbery, and to fight a subsequent duel with her father if necessary. A forcible allusion to the viking ability as helmsmen is made in II, 4. With exemplary beauty, Björn describes, in a monolog in III, 2, the barbarian custom of women entering the funeral-mounds of their husbands and being burned with them. In I, 5, the author makes Hildegard a descendant of Ulf Jarl, an historical character who, according to Sturleson, (Olof Haraldson Saga, Chap. 158), protected Denmark while Knut was in England in 1026. Hakon Jarl, the well-known saga hero and pagan champion, is mentioned by way of comparison in IV, I, and the historical Sven (Blotsven, i. e. Sacrifice-Sven), who burned the Uppsala temple, in II, I. A specific part of the poetic Edda, Havamál, comes in for a share of the glory in III, I. As an illustration of the use of Norse mythology, the following words of Björn in II, 4, will serve (he is speaking of the reported death of his friend Ragnar): " $\mathrm{He}$ has gone to his fathers! $\mathrm{He}$ has already pressed their hands in greeting and emptied the drinking-vessel with them, heard the harp of Brage, interpreted the riddle of life with Mimer, and seen his life reflected in Urda's wave."

"Hildegard" discloses a wide reading of saga material but there is no allegiance to any one particular tradition. The Norse element is concentrated in a subordinated character, Björn, who corresponds to Oldur, Palnatoke, and Hakon Jarl. Just as "Hildegard" did not attain the popularity of some of his other dramas, even if there were some notable contemporary exceptions to this rule. Better known dramas are: "Erik XIV," “Birger och hans ātt," "Gustaf Adolf i Tyskland," and "Torkel Knutsson." 
Nicander's Oldur, Beskow's best portrayed character is the old viking representative Björn. Nicander had other heathens appear also, such as peasants, fighters, a viking lawgiver, and the hero Alrik himself. In "Hildegard," also, there is considerable of the viking left in the converted Ragnar, the father of the heroine. In fact, we have more definite information about his viking escapades than about any of those in "The Runesword." Between Ragnar's family and his father-in-law's there had existed of yore a bitter race hatred. Ragnar had captured his wife with the sword and slain her father in the single combat that followed. ${ }^{1}$ He seems to forget that he is a Christian in the last scene, obtains his sword from Björn, and dies on it with these words:

Som viking jag begynt, som viking slutar jag lifvets kamp. ${ }^{2}$

Now to come back to Björn. He was once besprinkled with water and is a nominal Christian (Act I, sc. 2), but in reality is a hardened, unbending viking with everything that name implies. He can look back upon a career full of wild adventure -which might be true of a viking like Oldur-but he is more frank and explicit about his former combats, and is therefore, a more sharply drawn type than Oldur. He has more individual traits. He is more of the real primitive Norseman. Deeds, bravery, and character mean more to him than titles or noble lineage. To him the farmer's son is on a par with the prince (cf. I, 5). There is no haze whatever to obscure the confessions of this epic-dramatic character. He speaks with apparent pride of earlier misdeeds-which to him are, naturally, deeds of valor-and his barbarism is a part of his moral conviction. He is sincere and firm; he speaks once only and then, if necessary, affirms with the sword. Then, when we learn in the fourth act (sc. I) that he has burned Christian

1 This constitutes his "crime" which he must atone for, as a Christian.

2 "I have commenced and end the strife of life as a viking."

3 Tegnér, who believed "Hildegard" to be a "very excellent production," preferred Björn to all the other characters. The scene where Ragnar dies in his armor receives special mention, also, as an effective scene. See letter to Beskow of October I3, I836. Jubelfestupplaga, VI, pp. 293-94. 
temples and slaughtered women and children, we know that he has been a viking of the most dreaded type.

Björn-whose very 'name "bear" is significant and typical - is a sturdy champion of the old gods and a pronounced skeptic as to the new religion. On an auspicious occasion he is willing to sacrifice his dearest possession, his battle-horse, to Thor and Odin, whom he believes propitious to "an old viking" $(I, 2)$. The religion of his ancestors represents strength, whereas the new teachings have weakened men. The doctrines of love and peace, to Björn, represent a "life of milk and water" (I, 3). The custom of fasting "puts no marrow into the bones" (II, 2). The Catholics are ridiculed for " singing the soul to rest for pay." Let the mortal die by the sword and he will rest in peace like his forefathers without any singing-is the idea in Act II, r. He speaks slightingly (II, 2) of a heathen who has been carried away by a "man with goat-legs and long horns," because he would not become a Christian. Björn knows only fearlessness and fight; sword and victory are his only joy. He prefers to polish weapons -it will be remembered that Oldur is grinding his sword at the beginning of "The Runesword"-and to possess the "hammer-emblem" instead of the cross. For a time, much as in "The Runesword" and in "Hakon Jarl," Björn sees that his faith is symbolic and not so different from Christianity, except in application; but, on the other hand, "women's tears, lamentations, heart-pains, and natural deaths," have no place in Björn's system of life (III, 2).

The traditional disdain among the pagan Norsemen for a natural death was rooted, as is well known, in the fundamental principles of their religion: the blessedness of the fallen heroes in Valhalla. In this particular, Björn is a type. In Act II, sc. 4 , he makes his confession:

- “den tro jag lärt af mina fäder gör lifvet ljust och friskt, och döden herrlig."1

This death may be self-inflicted, especially when it is in the

1 " The faith which I have learned from my forefathers makes life bright and fresh, and death glorious." 
nature of a sacrifice. Björn rejoices at what later proves to be a premature report of Ragnar's death. Ragnar, upon crossing the Baltic on his return from Jerusalem, had courageously appeased the anger of the gods by jumping into the sea. To Björn this was an ideal death for a viking, who needed no other sepulchral vault than the blue sky and the stars; no other funeral dirge than the harp of the water-sprite (II. 4). In Act III, sc. I, Björn expresses his readiness to follow Ragnar and die himself before sunset. He asks Thiodulf, Hildegard's lover, to give him a "filled horn" when he is ready to fly to Odin, in order to empty it to the "memory of Ragnar, to the glory of the North, and for the gods of Valhalla." The following is typical for our viking; it is Björn's advice to Thiodulf $(\mathrm{IV}, 3)$ :

"Tro icke quinnan, yngling. Icke ens om hennes namn är Hildegard. Hon liknar den vackra blomman, hvilkens doft ger döden.

Vig dig, som jag, vid svärdet. Om det brister, så dör du samma stund och ej vanärad."'1

1 " Put no faith in woman, youth. Not even if her name is Hildegard. She resembles the beautiful flower whose fragrance yields death. Marry the sword like myself. If that breaks you will die the same moment andi not dishonored." 


\section{CONCLUSION}

There were all degrees and varieties of interest in the Old Norse element during the Swedish Romantic period. It reached its boiling-point finally among the extreme militant Goths, for these were saga enthusiasts by confession and profession, and the best example of this type is Ling. But a spasmodic and often enthusiastic interest had existed long before the Goths appeared, and more particularly among the members of that literary coterie known later as the Fosforists. Whatever the contemporary effect was, the fact remains, also, that Atterbom's "Skaldarmal" appeared before the Gothic organ Iduna. Then there were some minor adherents of the Old School, who were undoubtedly influenced to a certain extent by the new tendencies, and who treated saga themes in the old style. These conservatives were not especially enthusiastic about the inner content of the sagas; they cared little for the genuine spirit and philosophy and of the new mythology, but wrote creditable poetry with sagas as a basis. Among these were Adolf Granberg and Charlotta d'Albedyhll. A fullfledged and independent Romanticist, who sought to penetrate the very depths of vikingism and to reconcile it with Christianity, with personal experiences, and modern Romantic ideals, was Stagnelius. He knew Norse mythology as well as any Goth, probably, and certainly better than most of them. Lastly, we have two important dramatic productions where the interest in the saga age is epic and general: "The Runesword" and "Hildegard." These were both conceived during the Romantic period (and the first one completed) by the independent authors who were not elected to membership in the Gothic Society until some years later. In both of these dramas there is an effort to reconcile Norse paganism with Catholicism, i. e., Christianity, and in both of them the portrayal of the pagan element is the most successful.

Of no little importance was the negative interest in Old 
Norse material during the second decade of the nineteenth century. Nothing that the Fosforists did along Gothic lines gave any cause for alarm. But the somewhat tactless methods adopted at first by some Goths did give rise to a certain apprehension in conservative circles. The result was a crusade against "Gotho-mania" by those who feared neglect or expulsion of the old classical mythologies. This crusade was not conducted along strict party lines. The Gothic house was divided against itself, and unnecessarily so, for the differences of conception among its members were not as great as supposed and were often based on misunderstanding. Time proved that there had been little cause for solicitude in the first place. Those who did not take part in direct polemics resorted to ridicule. The Academician Stjernstolpe, for instance, attacked all Gothism, and the Romantic humorists Vitalis and Dahlgren poured light ridicule over exaggerations of it. But the whole affair did have a healthy influence; it stirred things up. Everybody was forced to recognize at least the existence of an indigenous material, which might be used as a basis for a national art and poetry. Then also, anybody who took a part in the controversy at all, whether for or against, was compelled to read the Old Norse literature to some extent; it took considerable knowledge of Scandinavian mythology to ridicule it intelligently.

All of the important Fosforists studied the Scandinavian myths, but no Gothic masterpiece came from their hands. Hammarskjöld was interested in the sagas but preferred to leave them as such, without introducing them into Swedish art or poetry. Livijn was very enthusiastic about them, especially during the first decade of the century, and formulated a multitude of literary plans with Gothic themes, but he became otherwise employed and plans came to naught. What little he did was fragmentary. Atterbom's work in this line during the strictly Romantic period, save "Skaldarmal," was limited to reviews and active encouragements, but he showed a genuine enthusiasm and was a scholar and philosopher in the interpretation of Norse myths. That Atterbom exerted some influence in this field is tolerably certain. 
The old Norse sources employed by the Swedish writers of the Romantic period were not very extensive. In many cases the poetic products reveal only a general knowledge of olden times, beliefs, and literary monuments. In the case of Atterbom, Stagnelius, and Nicander (in the "Runes"), however, we have undeniable evidence of a more detailed acquaintance with specific sagas. The Eddas are naturally of the greatest importance for a thinker like Atterbom; Sturleson's Heimskringla seems to be well known and very popular, both in Academician circles and with Stagnelius; and Nicander borrows themes from the famous cycle of Fornaldar Søgur. Some more modern histories of Scandinavia are used and Livijn, for instance, knows Saxo Grammaticus.

It is certain that the Goths were responsible for only a part of the so-called Gothic revival in Sweden. The honor and responsibility for the inauguration and permanent establishment of this commendable movement in Swedish literature must be shared with their Romantic brothers the Fosforists, and to a greater extent than at first supposed. It must be shared to a less degree with neutrals and some Academicians, and with such individuals as Stagnelius, who was a member of no society, but represented the deepest of all Romantic and Gothic ideals. In no case was there such a general ignorance of Norse mythology among the Tieck-Novalis-Schelling group of Swedish Romanticists as among the Goths themselves. Atterbom, Livijn, Stagnelius, and Nicander, all knew a number of sagas and myths thoroughly; whereas among the Goths, any valuable knowledge of Old Norse subjects was concentrated in the minds of only two or three men, an extremely small number in proportion to the total number of members. Both in aspiration, encouragement, and actual creation the non-Goths did a noble work along national lines, and did much to prepare the field for the reception of that Gothic masterpiece, which came as the culmination of the Gothic revival: Tegnér's "Frithiofs Saga." 


\section{APPENDIX}

\section{Supplementary Biographical and Critical Notes}

\section{(Arranged alphabetically)}

\section{Per Daniel Amadeus Atterbom (1790-1855)}

The greatest of the Fosforists was born in Östergötland, Jan. 19, I790. His childhood was very peaceful and idyllic and later furnished inspiration for many of his beautiful lyrics. Atterbom attended school and the gymnasium in Linköping, at sixteen he became a student at Uppsala, and studied the German philosophers and Romanticists. His part in founding the Aurora Union has been mentioned. He was the foremost contributor to Fosforos and edited Poetisk Kalender from $\mathrm{I} 8 \mathrm{I} 2$ to I822. From I8I7 to 1819 he lived abroad, and on his return became prince Oscar's tutor in German. For a time he was professor of philosophy in Uppsala, but later exchanged this position for the chair of esthetics. In later life he became reconciled to his former literary adversaries and was admitted to the Swedish Academy in 1839 . In his momentous but unfinished work "Swedish Seers and Skalds" (Svenska siare och skalder), which deals with philosophers and poets before and through the reign of Gustavus III, Atterbom is less harsh in his estimate of the Gustavian writers. Atterbom's domestic life was remarkably happy and a late edition of "The Isle of Bliss" is dedicated to the memory of his departed wife. He outlived most of his friends and died July 2I, 1855, in Stockholm.

As a poet, esthetician, critic, and historian of literature, Atterbom exercised a vast influence on Swedish letters and culture. "The Isle of Bliss" and the fragmentary "BlueBird" (Fogel blå) are both fairy-tales in dramatized form. But Atterbom was no dramatist; he was a lyric poet, and as such he ranks unquestionably as one of the greatest in Sweden, 
notwithstanding symbolism, obscurantism, and strange cosmic conceptions which permeate portions of his lyrics. Atterbom represents the culmination, the tout ensemble of the "oändlighetspoesi" in Swedish Romanticism. Among his most famous poems is the collection called "The Flowers" (Blommorna), a lyrical vegetation marked by beauty and originality but highly figurative and obscure. (Cf. Thomander: InträdesTal öfver Atterbom. Svenska Akademiens handlingar ifrån I796, Del 29.)

\section{Bernhard von Beskow (1796-1868)}

Beskow was born in 1796 and at an early date began to study music and painting. In $1819-1821$ he traveled in Europe and met Goethe, Tieck, F. Schlegel, and Oehlenschläger. In 1827-1828, the time of the struggle between the French classicists and Romanticists, we find Beskow in France. There he learned to know Hugo and took the opportunity to correct some erroneous statements about Swedish literature in Le Globe. Beskow was both a fascinating dramatist and an able composer of operas. $\mathrm{He}$ was a member, secretary, and prize-taker of the Swedish Academy, a member of the Swedish Academy of Music, and of a number of French and Danish societies. From a copyist in the department of finance of the king's chancery he worked his way up to chamberlain at the court. His drama "Erik XIV" was particularly well received; it was translated into German, and parts of it into English and Danish. Beskow died in 1868. (Cf. Palmblad: article on Beskow in Biografiskt Lexikon, Vol. 2, 1836.)

\section{Carl Fredrik Dahlgren (I79I-I844)}

Dahlgren was a gifted poet, noted for his sane and realistic descriptions of nature and for his delightful humor. In his famous "Epistles of Mollberg" (Mollbergs epistlar) he took Bellman for his model and wrote in a light and original vein. Dahlgren, who was a clergyman, is said to have been a good preacher and pastor, and a very popular man in society. His pleasant shafts of humor were directed at everybody and not even the Fosforists (to whom Dahlgren once belonged) escaped. 
There was no great depth in his poetry, but neither was there any unfathomable metaphysics, and so he was best in his clear, simple, and "sunny spring-dithyrambs." Dahlgren also composed popular ditties and kept a salon in the thirties for Young Sweden. Later he became a politician and member of the Riksdag. (Cf. Vetterlund: Notes on Dahlgren in introduction to "Svensk romantik," II, of Svensk national-litteratur.)

\section{Per Elgström (I78I-I8ro)}

Per Elgström, an important member of Aurora, was born on Christmas Eve 1781 , in the province of Småland, and his mother was a poor peasant's daughter. He studied German philosophy and poetry at Uppsala and took his master's degree in 1809. For a time he was tutor in the house of a nobleman and clerk in the ecclesiastical department in Stockholm. He contributed to Polyfem and to the first numbers of Fosforos. His untimely death of consumption October 28, 1810, was the cause for deep mourning in Fosforistic circles.

\section{Erik Gustaf Geijer (1783-1847)}

The literary standard-bearer of the Gothic union during its first, hurricane-period was born in Värmland, January I2, I783, and descended from an old family which had emigrated to Sweden from Germany in the early part of the seventeenth century. At twelve Geijer entered Karlstad gymnasium and only four years later matriculated at Uppsala. He had no definite profession in mind but studied the classics, history, and, at spare moments, music. $\mathrm{He}$ was a student of only moderate means and supported himself by tutoring. In 1803 he captured the prize offered by the Swedish Academy for the best work on the memory of Sten Sture, three years later he was made master of arts, and in 1808 received a welcome stipend. In 1809 he went to England and upon his return the year after, he was appointed docent in history at his Alma Mater. He was promoted to "adjunct" with right to lecture in $18 \mathrm{I}_{5}$, and was made full professor after two years. Lydia Wahlström (Erik Gustaf Geijer, p. 226,) divides Geijer's 
mature activity into the following periods: from 18 Io to 1820 , the "special philosophical"; from 1820 to $\mathrm{I} 838$, a term of activity in history and in conservative, practical politics; and, finally, from 1838 to his death in 1847 , the liberal philosophical period. Geijer is to be remembered as a popular teacher, a music enthusiast and composer, a conscientious, scientific historian, an essayist, a philosopher, and member of the Riksdag. $\mathrm{He}$ was an intimate friend of Atterbom and of the worldrenowned singer Jenny Lind. The significant influence of Hans Järta's friendship for Geijer's development is historical. Of Geijer's more pretentious works the following two deserve special mention: "The Annals of Sweden" (Svea rikes häfder) and "The History of the Swedish People" (Svenska folkets historia). (For an account of Geijer's life and works, with analyses of important publications, consult Lydia Wahlström: Erik Gustaf Geijer, Stockholm, I907.)

\section{Lorenzo (Lars) Hammarskjöld ( $1785-1827$ )}

Hammarskjöld, the foremost pioneer to proclaim the new ideas from Germany, was born April 7, 1785. He first received instruction at home and, after the loss of his father at the age of fourteen, his older brother Åke helped him to continue his studies elsewhere. He matriculated at Uppsala in I8OI and studied in almost every humanistic field. He was not a good student, however, never became much of a philologian, and was not "promoted" in 1816 , though he took his master's degree six years later. His youth was not free from Weltschmerz or eccentric plans of life; he read "La nouvelle Héloise" and "Werther," wished to be a soldier or a bandit, and had an unhappy love-affair; for his sweetheart, Eleanora Rääf, married his brother. But early troubles had no unwholesome effect upon Hammarskjöld, and in 1806 he was appointed assistant (amanuens) in the Royal Library in Stockholm. His most influential work, as we have noted, was as a programmaker, as critic of esthetics, and as an historian of literature and art. His large correspondence at the Royal Library is the best first-hand source for the study of the development of the 
New Movement, and a great many of his letters have been published. Hammarskjöld died in I827. (Cf. letters; Biografiskt Lexikon, article on Hammarskjöld, and Svenska vitterhetens historia, III, 579ff.)

\section{Samuel Johan Hedborn (I783-1849)}

Hedborn was born October I4, I783, in a poor soldier's home in Östergötland. Personal impressions of childhood became of paramount importance in his later development. He attended school and gymnasium in Linköping, was a member of the Aurorabund, and a contributor to the publications of the Fosforists. In 1809 he was ordained to the ministry, in 1820 he became pastor in an isolated place in Småland and thereafter lived a secluded life, though he never ceased to write entirely nor to keep in touch with his friend Atterbom. Hedborn possessed the gift of pure lyric, a fresh naiveté, and Atterbom characterized him as the poet of nature, childhood, and religious devotion. He wrote some splendid hymns and was probably the greatest of the minor Fosforists. He died December 26, I849. (Cf. Biographical note on Hedborn in Vetterlund's introduction to "Svensk romantik" in Svensk national-litteratur, Vol. IX.)

\section{Johan Henrik Kellgren (I75I-I795)}

Kellgren was a leading representative of the Old School and famous as a critic and esthetician. At first he strenuously defended the French system of esthetic principles, but later he anticipated the new literary movement by deviating somewhat from its stern rigidity and then wrote poems with deep feeling and in a sublime style. Baggesen and Klopstock were among his later favorites. Hammarskjöld calls Kellgren's "The New Creation, or the World of Imagination" (Nya skapelsen eller inbildningens verld) "the most excellent lyrical production in our (i. e., Swedish) language before I8Io." Cf. Hammarskjöld: Svenska vitterheten, 2d edition, pp. 334-335.)

$$
\text { Karl Gustaf af Leopold (1756-1829) }
$$

Leopold must be mentioned here again as being the sworn enemy and the target, par excellence, of the New School. 
After the death of Kellgren in I795, Leopold became the leading veteran of the Gustavian party. He wrote didactic poems, odes, poetic epistles, satires, and tragedies in the French style. He possessed a broad culture, a sparkling wit, a vast knowledge, and a complete mastery of form. But he clung tenaciously to the sense commun method of reasoning and had no deep feeling or brilliant talent to offset his blemishes. (Cf. Horn: Scandinavian Literature, pp. 357-358.) Hammerskjöld declares rather pointedly that Leopold's aim in life was to become "a Voltaire in Swedish translation." (Svenska vitterheten, 2 d edition, p. 466.)

\section{Per Henrik Ling (1776-1839)}

The "founder of scientific gymnastics," Per Henrik Ling, was born in the province of Småland, November I5, I776. His father, a priest in Ljunga, died when Per was only four years old and his mother married the successor to the Ljunga pastorate. At nine Per was sent off to school in Växjö and his mother died a few years later, so that Ling only barely remembered even his mother. In I790 we find Ling attending the gymnasium, but he made little progress, and after being instrumental in smashing the windows of the rector's house he left suddenly one night, and was then officially separated from the gymnasium. He matriculated at the University of Lund in the spring of $\mathrm{I} 793$ but was soon obliged to leave for lack of funds. Where he spent the next two or three years remains a puzzle, but he seems to have been in Stockholm part of the time, earning his livelihood by tutoring and translating. In I797 he took an unimportant examination in theology at Uppsala, and in 1799 came the turning-point in his career when he left for the Danish capital to continue his studies. In Copenhagen he taught modern languages, made the acquaintance of Oehlenschläger and Steffens, commenced the study of Norse mythology, and took up gymnastics for his health. Ling moved back to Lund in 1804 and became teacher of fencing at the University the year after. He combined the study of anatomy and physiology with the writing of poetry and worked out plans 
for historical tragedies. The development of both body and soul, combined with the training of the imagination, was to be the guiding motto in Ling's life. Tegnér, on whom Ling exerted such an epoch-making influence, helped his friend to obtain, in 1813 , the position as instructor in gymnastics at the Karlberg military school in Stockholm. While in the capital Ling became acquainted with a large number of artists and men of letters, but would have nothing to do with the Fosforists. $\mathrm{He}$ joined the Goths, however, soon after his arrival. In I8I5 the Swedish Academy awarded him the Lundblad prize for "Gylfe," and this official recognition of his poetic ability no doubt did much to encourage subsequent and more titanic efforts. Ling's life was not free from material solicitude, but with an iron will the poet-gymnast overcame all obstacles. In I8I 7 he lost his first wife, leaving a young daughter. Two years later he married Charlotta Katarina Nettelbladt by whom he had seven children. With the title of professor, Ling left Karlberg in I825 and afterwards devoted most of his time to The Central Institute (Centralinstitutet) in Stockholm, a school established in I8I4 for the scientific training of gymnasts. Ling died May 3, I839. (Cf. Lydia Wahlström: Den svenska odlingens stormän, Vol. V.)

\section{Clas Livijn ( $178 \mathrm{I}-\mathrm{I} 844$ )}

Clas Livijn was born on November I, I78I, and died as a prominent lawyer October 12, 1844. His father, a clergyman, died in 1802 , and this caused an unpleasantness in the family which seriously affected the son. For a time he had difficulty in choosing a profession. He had matriculated at Lund in October I800, but in the autumn of 1802 he entered Uppsala, where he took his examination in law in 1805 . His life, and more particularly his youth, was a constant see-saw of happiness and despair; he hovered between absolute indifference and boundless ambition, and this together with his ironical, skeptical mind is said to have been provoked thoughts of suicide. He was a typical Stürmer und Dränger, sensitive, witty and interesting. As a young poet Livijn failed to obtain recog- 
nition by the Swedish Academy and so afterwards ridiculed it. $\mathrm{He}$ was an ardent friend and admirer of Hammarskjöld, with whom he kept up a lively correspondence, and the latter reciprocated the admiration by dubbing Livijn "the coming Swedish Goethe." (See Svenska vitterhetens historia, III, p. 59r.) Livijn's early inclination for English literature, his sympathy for German classics, and his spasmodic interest in Old Norse make him a most important forerunner of Swedish Romanticism. Livijn made translations from Tieck, considerably later his own "Queen of Spades" (Spader dame), r823, was in turn translated by Fouqué, and Livijn's opera "The Mermaid" (Hafsfrun) "was probably the first Romantic drama written in Sweden.” (Cf. Biogfiskt Lexikon, Vol. 8: article on Livijn.) Livijn was also actively connected with Polyfem, and the precise amount of his contribution has in recent years been pretty well established. That he was not the famous writer who signed himself "Nils Nyberg" seems certain; this honor is now bestowed upon Hammarskjöld. (Cf. Svenska vitterhetens historia, IV, p. 87 and note.)

\section{Carl August Nicander (1799-1839)}

Nicander was born in Strengnäs. During his boyhood he formed a warm friendship with Sjöberg-Vitalis, which became of the utmost importance for both, and which only terminated in Vitalis's death. While Vitalis was gloomy and bitter toward humanity, Nicander was mild, gentle and lovable. In his occasional weakness Nicander was often encouraged and strengthened by his friend who, undoubtedly, received some well-needed comfort in return. Nicander often suffered from want and misery, and never had any fixed position in the community. We find him in Uppsala in I8r7. In 1827 he traveled south on a stipend and after his return we can detect a deep mourning for Italy in his poetry. Many of his best poems are written in Italian and German. Nicander also made translations from Schiller ("Die Räuber" and "Die Jungfrau v. Orleans") and Shakespeare ("Othello"), and wrote some of the best sonnets in the Swedish language. In 1830 he published "Reminiscences from the South" (Minnen från södern) and "Hespe- 
rider," a collection of poems and tales. Other significant works, besides "The Runesword," are "Tasso's Death" and "King Enzio, the Last Hohenstaufen." His collected poems, in four parts, have gone through several editions. When $\mathrm{Ni}$ cander died in 1839 it was found at the post-mortem examination that he had suffered and finally succumbed to the same disease as Stagnelius, enlargement of the heart, this organ having grown to twice its natural size. (Cf. Life of Nicander by Mellin in Vol. 4 of Samlade dikter, Stockholm, I84I.)

\section{Wilhelm Fredrik Palmblad ( $1788-1852$ )}

One of the founders of the Aurorabund was W. F. Palmblad who remained a zealous champion of the Fosforists. $\mathrm{He}$ wrote some insignificant poems and some mediocre novels, "The family Falkensvärd," (Familien Falkensvärd) and "Aurora Königsmark," but his chief celebrity was gained as controversialist, biographer, editor, and publisher. For twentyfive years, beginning I8Io, Palmblad was manager of the academic printing establishment in Uppsala, which sent out Fosforos, Poetisk Kalender, and Svensk Literatur-Tidning. Palmblad was contributor to several literary periodicals and did work in Persian and Hindu antiquity. In $\mathrm{I} 835$ he began to edit "Biografiskt Lexikon" and wrote many of the articles himself. $\mathrm{He}$ possessed a good sense of humor, was unusually witty, and entertained royally "under the low roof of his first printingoffice," where the English and German authors were read and discussed. Atterbom characterizes Palmblad as "one of the most learned men who ever wrote novels," and declares that a Swedish publicist had never existed who could be compared to him in geographical, statistical, historical, and political knowledge. (Cf. Atterbom: Minnesteckningar och tal. Senare bandet. Örebro, I869, p. 205.)

\section{Erik Johan Stagnelius (1793-1823)}

This dreamy and hypochondriacal but highly gifted poet was born on the Island of Öland in I793. His father was a professor and minister who later became Bishop of Calmar. The 
young Stagnelius speedily devoured everything in his father's library and when he left for the academy he was splendidly equipped in Norse mythology and the classics. He studied first at the University of Lund and then at Uppsala, where he took his examination for the chancery (Kansli-examen) in I8I4. He lived a secluded life as a chancery-clerk in Stockholm and was little noticed while he was alive. He never took any part in the fashionable literary polemics of his age, but devoted his time to creative productions and to a strange, melancholy, mystic-pantheistic reflection. Stagnelius never married, but his poems have the tone of disappointed love, though his father denied the contention that his son had ever suffered from an unrequited affection. His poetic activity lasted only about eleven years, beginning 1812 , but during that period he wrote enough idylls, elegies, sonnets, odes, romances, pure lyrics, epics and dramas to gain the deserved reputation of a great poet. His best known works, in addition to those with Norse motives, are: the epic "Vladimir the Great" (Wladimir den Store); "Bachanterna," a tragedy; the religious drama "The Martyrs" (Martyrerna); "The Knight's Tower" (Riddartornet), a Romantic drama; and that "half philosophical and half religious cycle of poems" "Lilies of Sharon" (Liljor i Saron). Stagnelius suffered from heart-failure, which gradually undermined his young life, and one morning in 1823 he was found dead in bed. The works of Stagnelius have been translated into German by K. F. L. Kannegiesser, Leipzig, 6 vols. I85I. I have not seen this translation. (Cf. Introduction by Hammarskjöld in part I of his edition of Stagnelius's Samlade skrifter; also, supplement at end of part 3.)

\section{Esaias Tegnér (1782-1846)}

The author of "Frithiof's Saga," the greatest writer of the Swedish Romantic period and, undoubtedly, the best known Swedish poet of all times, needs but little consideration here. In connection with our specific topic, however, it becomes necessary to call attention to an apparently wrong impression about Tegnér's relation to the Romanticists, an impression which is 
more especially entertained by foreign historians of Swedish literature. For instance, Bernardi in "La Littérature scandinave" (Paris, I894, p. 64) calls Tegnér the head of the Gothic School, and either ignores the Romantic movement under German influence entirely, or knew nothing about it. To Bernardi, Bellman and Tegnér are the only names of the whole Romantic movement worthy of mention, and such an unconditional dismissal of the subject is not only misleading but morally unjust. Tegnér was not the militant head of any school but above all schools. He was elected a member of the Gothic group, to be sure, he eventually became its greatest literary exponent, he contributed to Iduna, and ultimately acquired his greatest claim to a cosmopolitan immortality by the treatment of a Norse theme in accordance with Gothic principles; but Tegnér was never guilty of the Gothic exaggerations and openly opposed the Fosforists. Tegnér was a leader in poetic art, pure and simple, and no slave who abided strictly by the formulated dogmas of any one literary faith.

Tegnér was born November I3, I782, in Värmland. After the death of his father, a clergyman, young Tegnér found patrons who assumed care of his studies. At twenty years of age he became docent of esthetics at the University of Lund, in 1806 he married, in 1812 he was ordained to the ministry, and also became professor of Greek in Lund. A learned Hellenist and popular lecturer, he was dean of the faculty of philosophy from I8I4 to I823, and the following year he was appointed Bishop of Växjö. In 1833 he journeyed to Bohemia for his health and on the way met Schleiermacher, Steffens, and others. Liver trouble and a consequent recurring of melancholia affected his mind, so that in 1840 Tegnér was taken to an asylum in Schleswig for treatment. He recovered sufficiently to take up his work again, but he never regained his former vigor and died November 2, I846. The following poems will give any reader an estimate of Tegnér's power: "War-song for the Militia of Scania" (Krigssång för skånska landtvärnet), ı 808; the prize-poem "Svea," I8I I " Nore," I8I4; "New-Years I816" (Nyåret I8I6) ; "The Children of the Lord's Supper" 
(Nattvardsbarnen), I820, translated by H. W. Longfellow ; "Axel," a narrative poem, I82I ; and "Frithiof's Saga," I825. The latter has been translated into almost every European tongue. There are at least twenty-five different translations of it into German and twenty-two into English, the last one by Clement B. Shaw of Chicago. (Cf. Introduction to the Nationalupplaga of Tegnér's Samlade skrifter, by Böttiger; also Brandes: Esaias Tegnér.)

\section{Erik Julius Sjöberg-Vitalis ( $1794-1828$ )}

Vitalis was born in Södermanland in I794. His father was a poor workman and his mother a minister's daughter. $\mathrm{He}$ exhibited in early youth a marked gift for study and poetry so that his friends helped him to obtain an education. He entered the gymnasium in I809, but left suddenly in I8I4 and went to Uppsala. Vitalis's whole life is a record of hardships; he was always poor but too sensitive to accept material aid without humiliation, he suffered immensely from an incurable physical malady, and contracted debts, but managed to support himself, after a fashion, by tutoring and translating. He received a stipend in 1822 and by a most extraordinary will-power succeeded in taking his doctorate of philosophy in I824. Though a friend of Nicander, as we have seen, he attacked both the Fosforists and Goths, and in so doing displayed a decided talent for satire and humor. To better his chances Vitalis moved to Stockholm in 1827 , but found only more trouble and, in the following year, death. (Cf. Carl L. Östergren: Vitalis, hans lif och diktning, Uppsala, I869.) 


\section{BIBLIOGRAPHY}

(Grouped in the order of their importance)

\section{Literary Periodicals}

Iduna. No. I-II. Stockholm, I8II-I845. (For first numbers, later editions used.)

Journal för Litteraturen och Teatern, I809-I8I3. Then continued as:

Allmänna Journalen, I813-1822. Stockholm.

Poetisk Kalender. Uppsala, I812-1822.

Phosphoros (Fosforos). I8Io-1813. Printed in Uppsala. Polyfem. Första-Femte samlingen. Stockholm, I809-1812.

Svensk Litteratur-Tidning. Stockholm och Uppsala, I813I824.

\section{Miscellaneous Literature of Specific Importance} d'Albedyhll, Eleonora Charlotta, Gefion. Skaldedikt i fyra sånger. Uppsala, I8r4.

Atter'bom, P. D. A., Samlade dikter. I-6. Örebro, I854-1863. Inträdes-Tal i Svenska Akademien öfver Pehr Henrik Ling. Svenska Akademiens handlingar ifrån 1796. Del 20. Stockholm, I843.

Samlade skrifter i obunden stil. I-VII. Örebro, I8591870. Containing:

Inledning till svenska siare och skalder, fjerde delen, I864. Minnesteckningar och tal. Två delar, 1869 .

Literära karakteristiker. Två delar, I87o.

Beskow, Bernhard v., Dramatiska studier. Stockholm, I8361838. Lefnadsminnen. Stockholm, r87o.

Böttiger, Carl Wilhelm, Aurora-Förbundet i Uppsala. Svenska Akademiens handlingar ifrån år 1796 . Del 49. Stockholm, 1874 .

Minne af Erik Johan Stagnelius. (No date. Probably Stockholm, 1872.) 
Fouqué, Friedrich, Baron de la Motte, Thiodulf the Icelander. London, 1865 .

Frunck, Gudmund, Bidrag till kännedom om nya skolans förberedelser och första utveckling. (Till år I8II.) Stockholm, I889.

Bref rörande nya skolans historia. Uppsala, I886-189I. Granberg, P. A., Jorund, lyrisk tragedi i tre akter. Svenska Akademiens handlingar ifrån I796. Del 6, pp. 265ff. Stockholm, i8I7.

Hallman, Mila, Clas Livijn, en studie. Med bihang: Spader dame. Stockholm, I909.

Hammarskjöld, Lorenzo, Svenska vitterheten. Andra upplagan af P. A. Sondén. Stockholm, I833.

Kritisch-historische Uebersicht des Zustandes der swedischen Literatur seit dem Anfange dieses Jahrhunderts. Hermes, Leipzig, Numbers XVII and XX, I823; and XXII, I824.

Utkast till de bildande konsternas historia, i föreläsningar. Stockholm, I8I7.

Hjärne, Rudolf, Götiska förbundet och dess hufvudmän. I. Stockholm, I878.

Dagen före drabbningen, eller nya skolan och dess män i sin uppkomst och sina förberedelser. I802-1810. Stockholm, I882.

Geijer, Erik Gustaf, Samlade skrifter, I-8. Stockholm, I874I876.

Ling, P. H. Samlade arbeten. I-III. Stockholm, 1866.

Ljunggren, Gustaf, Svenska vitterhetens häfder efter Gustaf III :s död. I-V. Lund, I873-I895. Smärre skrifter.

I and III. Lund, 1872 and $188 \mathrm{I}$.

Malmström, Bernhard Elis, Grunddragen af svenska vitterhetens historia. I-V. Örebro, I866-I868.

Molin, Adrian, Geijer-Studier. Göteborg, 1906.

Mortensen, Johan, Clas Livijns dramatiska författarskap. Stockholm, I9I I.

Nicander, K. A., Samlade dikter. I-IV. Stockholm, I839I84I.

Samlade arbeten. Tredje upplagan. I-II. Stockholm, I862. 
Norling, Börje, Nya skolan bedömd i literaturhistorien. Stockholm, I880.

Palmbiad, F. W., Biografiskt Lexikon öfver namnkunnige svenska män. Articles on Ling, Hammarskjöld, and Beskow.

Rafn, C. C., Fornaldar Sögur Nordrlanda eftir gömlum handritum. Fyrsta Bindi, Kaupmannahöfn, I829. pridja Bindi, Kaupmannahöfn, I830.

Rydqvist, Johan Er., Bernhard v. Beskow, Minnesteckning. Stockholm, I873.

Saxo Grammaticus: Danish History, First 9 books, Translated by Oliver Elton, B.A. London, I894.

Schück, Henrik, Ur gamla papper, containing Den götiska skolan. Stockholm, I904.

Snorre Sturleson, Konungasagor. Translated into Swedish by Hans Hildebrand. Stockholm, r889.

Stagnelius, E. J., Samlade skrifter. Utgifna af L. Hammarskjöld. Delar I-3. Stockholm, I836.

Samlade skrifter. Sjunde upplagan, af C. Eichhorn. Stockholm, I88I.

Sterner, Anders, Den nordiska mytens användning i bildande konst. Stockholm, I88I.

Sundén, D. A., Översikt av nordiska mytologien. Femte upplagan. Stockholm, I908.

Tegnér, Elof, Ur Esaias Tegnér's papper. Stockholm, I882. Tegnér, Esaias, Samlade skrifter. I-VII. Jubelfestupplaga. Stockholm, I882-1885.

Efterlämnade skrifter. I-III. I and II contain letters. Stockholm, no date.

Thomander, Johan Henrik, Inträdes-Tal öfver Atterbom, hållet den $29 \mathrm{Maj}$ I857. Svenska Akademiens handlingar ifrån år I796. Del 29. Stockholm, I857.

Vedel, Valdemar, Svensk romantik. Kфbenhavn, 1894. Wahlström, Lydia, Den svenska odlingens stormän. V. Per Henrik Ling. Stockholm, I902.

Erik Gustaf Geijer, en lefnadsteckning. Stockholm, r907. Westerblad, Carl August, Pehr Henrik Ling, en lefnadsteckning och några synpunkter. Stockholm, I904. 
Wirsén, C. D. af, Clas Livijn, hans verksamhet inom skönliteraturen och den literära polemiken. Stockholm, I870.

Lefnadsteckningar af $\mathrm{K}$. A. Nicander, pp. I73ff. Af Bern. v. Beskow, pp. 29Iff. Stockholm, r90I.

Wordsworth, John, Bishop of Salisbury: The National Church of Sweden (The Hale Lectures I9Io). London and Oxford, England, and Milwaukee, U. S. A., I9Ir. Östergren, Carl L., Om Vitalis, hans lif och diktning. Uppsala, 1869 .

\section{Bibliography OF Special Importance For INTRODUCTION}

Arentzen, Kr., Baggesen og Oehlenschläger. Literaturhistorisk studie. I-VIII. Kjøbenhavn, I870-1878.

Baggesen, Jens, Poesiens oprindelse, in Deel I, pp. I8-53 of Vaerker, I-8. Kjфbenhavn, I879-1882.

Blanck, Anton, Den nordiska renässansen i sjuttonhundratalets litteratur. Stockholm, I9II.

Castrén, Gunnar, Norden i den franska litteraturen. Helsingfors, I9ro.

Edda. I. Edda, Saemundar hinns Fróda. Edda Rhytmica seu antiquior vulgo Saemundiana dicta. Pars I, Hafniae, I787; Pars II, Hafniae, I8I8. Sumptibus Legati Magnaeani et Gyldendalii.

2. Edda, Saemundar hinns Fróda. Collectio Carminum veterum Scaldorum Saemundiana dicta. Ex recensione Erasmi Christiani Rask. Curavit Arv. Aug. Afzelius. Holmiae, I8I8.

3. Saemund den vises Edda. Translated into Swedish by Arv. Aug. Afzelius. Stockholm, I8I8.

4. Rasmus B. Anderson: The Younger Edda. Chicago, I880.

5. Icelandic Poetry, or the Edda of Saemund. Translated into English verse by A. S. Cottle. Bristol, I797. 
6. Hugo Gering: Die Edda. Leipzig und Wien. No date..

7. Die Brüder Grimm: Lieder der alten Edda. Erster Band. Berlin, I8I5.

8. du Puget, Mlle. R., les Eddas. Paris, 1846.

Ewald, Johannes, Samtlige skrifter. Bind I-4. Kjøbenhavn, I780-I79I.

Samtlige skrifter. Deel I-8. Kjøbenhavn, I850-I855. Fouqué, Friedrich Baron de la Motte, Der Held des Nordens. Berlin, I8Io.

Gerstenberg, H. W. von, Deutsche Nationalliteratur. No. 48. Containing "Der Skalde". (Gedicht eines Skalden). Also works of Kretschmann and Denis in the same volume.

Goethe, Johann Wofgang von, Dichtung und Wahrheit. Vol. 28 of Weimar edition.

Gräter, Fr. David, Nordische Blumen. Leipzig, I789.

Gray, Thomas, Works. Vol. I, Poems, containing The Bard, The Fatal Sisters, and The Descent of Odin. London, I8I6.

Gustaf III:s Skrifter. Andra delen. Stockholm, I806. See Frigga, pp. $307 \mathrm{ff}$.

Herbert, William, Select Icelandic Poetry. Translated from the original, with notes. London, I804-1806.

Herder, Johann Gottfried von, Iduna oder der Apfel der Verjüngung. Zutritt der nordischen Mythologie zur neueren Dichtkunst. Werke. Hrsg. von B. Suphan. Berlin, 1877-1899. Ueber Ossian u. die Lieder alter Völker, I773.

Klopstock, F. G., Werke. Deutsche Nationalliteratur. Bd. 46-48.

Macpherson, The Poems of Ossian. I-II. Edinburgh and London, I870.

Mallet, P. H., Histoire de Danemarc. Troisième édition, I-9. Genève, 1787-1789.

Nial-Saga. Historia Niali et Filiorum. Sumtibus Petri Friderici Suhmii et Legati Arna-Magnaeani. Havniae, Anno MDCCCIX. 
Oehlenschläger, Adam, Digte. Kiфbenhavn, I803.

Nordiske digte. Kiфbenhavn, I807.

Nordens guder. Kiфbenhavn, I819.

Poetiske skrifter. Kiфbenhavn, I896-I899. I-II, XIIXIII.

Dramatische Werke. Wien, I8I8.

Oxenstjerna, Johan Gabriel, Arbeten. Andra delen. Stockholm, i806.

Percy, Thomas, Reliques of Ancient English Poetry. I-III. London, I794.

Pram, C., Staerkodder, Et Digt i femten sange. Kiøbenhavn, I785.

de Saint-Pierre, Jacques Bernardin Henri, Etudes de la nature.

L'Arcadie. Troisième édition. Tome quatrième. Paris, I788.

Schimmelmann, Jakob, Abhandlung abgefasst in einem Schreiben an einen Gelehrten von der alten Isländischen Edda. Halle u. Leipzig, I774.

Stael-Holstein, Mme. de, De la littérature. Troisième édition. Tome I-II. Paris, I8I8. Especially chapters $\mathrm{XI}$ and XII of Tome I.

Sch $\varnothing$ ning, Gerhard, Afhandling om de Norskes og en deel andre Nordiske Folkes oprindelse. Sor $\varnothing e$, I769.

Suhm, P. F., Om Odin og den hedniske gudelaere of gudstienste udi Norden. Kiфbenhavn, I77I.

Historie af Danmark. From 803-I400. I-XIV. Kiфbenhavn, I782-I828.

Weiss, article on Comte de Tressan in Biographie Universelle. Nouvelle édition, Vol. 42.

\section{Works of a General Character.}

Bernardi, L., La Littérature scandinave. Paris, I894. Brandes, Georg, Esaias Tegnér. Kiфbenhavn, I878.

Translated (I) into Swedish by O. A. Stridsberg. Stockholm, no date. (2) Into English by R. B. Anderson in "Authors of the XIX Century," pp. I68ff. 
Dahlgren, Carl Fredrik, Samlade arbeten I-5. Stockholm, I847-I852. Contains, in Vol. I, life of author by A. I. Arwidson.

d'Ehrenström, Marianne, Notices sur la littérature et les beauxarts en Suéde. Stockholm, I826.

Fryzell, Anders, Bidrag till Sveriges litteratur-historia. I-9. Stockholm, 1860-1862.

Geijer, E. G., and A. A. Afzelius: Svenska folkvisor. New edition with several additions by $\mathrm{R}$. Bergström and Leonard Hoijer. Stockholm, I880.

Horn, Frederick Winkel, History of the Literature of the Scandinavian North. Translated by Rasmus B. Anderson. Chicago, rgor.

Kellgren, Johan Henrik, Samlade skrifter, I-II in one volume. Gefle, I884-1885.

Klemming, G. E., Sveriges dramatisk litteratur till I875. A bibliography. ז876. (No place.)

Lénström, Carl Julius, Svenska poesiens historia. Senare delen. Örebro, 1840 .

Leopold, Carl Gustaf af, Samlade skrifter. I-II. Stockholm and Uppsala, 1873 .

Léouzon-Leduc, L., Histoire littéraire du Nord. Première partie: Tegnér. Paris, 1850.

Nordisk Konversationslexikon. Stockholm, 1876-1894. Article on Nicander.

Puget, Mlle. R. du, Fleurs scandinaves. Paris, no date.

Schück, Henrik, och Karl Warburg: Illustrerad svensk-litteraturhistoria. I-II, in three volumes. Stockholm, 1897. See last half of II.

Schweitzer, $\mathrm{Ph} .$, Geschichte der scandinavischen Literatur im 19. Jahrhundert, pp. 128-202: Die romantische Schönliteratur Schwedens. Leipzig, no date.

Söderberg, Erik Natanael, Samuel Johan Hedborn. Doctor's dissertation. Uppsala, 1897.

Vetterlund, Fr., Från nyromantikens dagar. Stockholm och Uppsala, 1907 .

Studier och dikter. Stockholm, I90I. 
Introduction to Vols. IX and X of Svensk national-litteratur. Vols. IX and X comprise Svensk romantik. Stockholm, I908 and I9Io.

Vitalis (Erik Sjöberg), Samlade skrifter, with prefaces by $\mathrm{E}$. G. Geijer and C. A. Forselius. Stockholm, I873. 


\section{VITA}

Adolph Burnett Benson (Adolf Berndt Bengtson) was born in Skåne, Sweden, November 22, I88I. After attending a Folkskola in that place, he emigrated to United States in 1892. $\mathrm{He}$ attended the public school at East Berlin, Connecticut, and prepared for college at the Middletown (Conn.) High School. Entering Wesleyan University, he was graduated, magna cum laude, in 1907 with the degree of B.S. Then, for two years, while teaching German and French in Bellefonte Academy, Bellefonte, $\mathrm{Pa}$., he pursued graduate work, in absentia, under the direction of Professor Fife, of Wesleyan University, receiving the degree of M.S. in I9IO.

He has spent two years, from I909-I9II, in post-graduate study at Columbia University in the fields of Germanic Languages and Literatures and French Language and Literature. The first year he was University Scholar and the second University Fellow in Germanics, receiving the degree of A.M. in 1910. His resident graduate work has been done under Professors Calvin Thomas, W. H. Carpenter, Remy, Tombo, and Loiseaux. 


$$
18^{6^{7965}}
$$





\section{RETURN CIRCULATION DEPARTMENT TO $\rightarrow \quad 198$ Main Stacks}

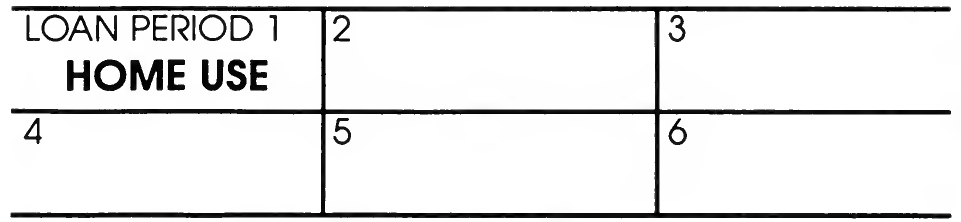

ALL BOOKS MAY BE RECALLED AFTER 7 DAYS.

Renewls and Recharges may be made 4 days prior to the due date. Books may be Renewed by calling 642-3405.

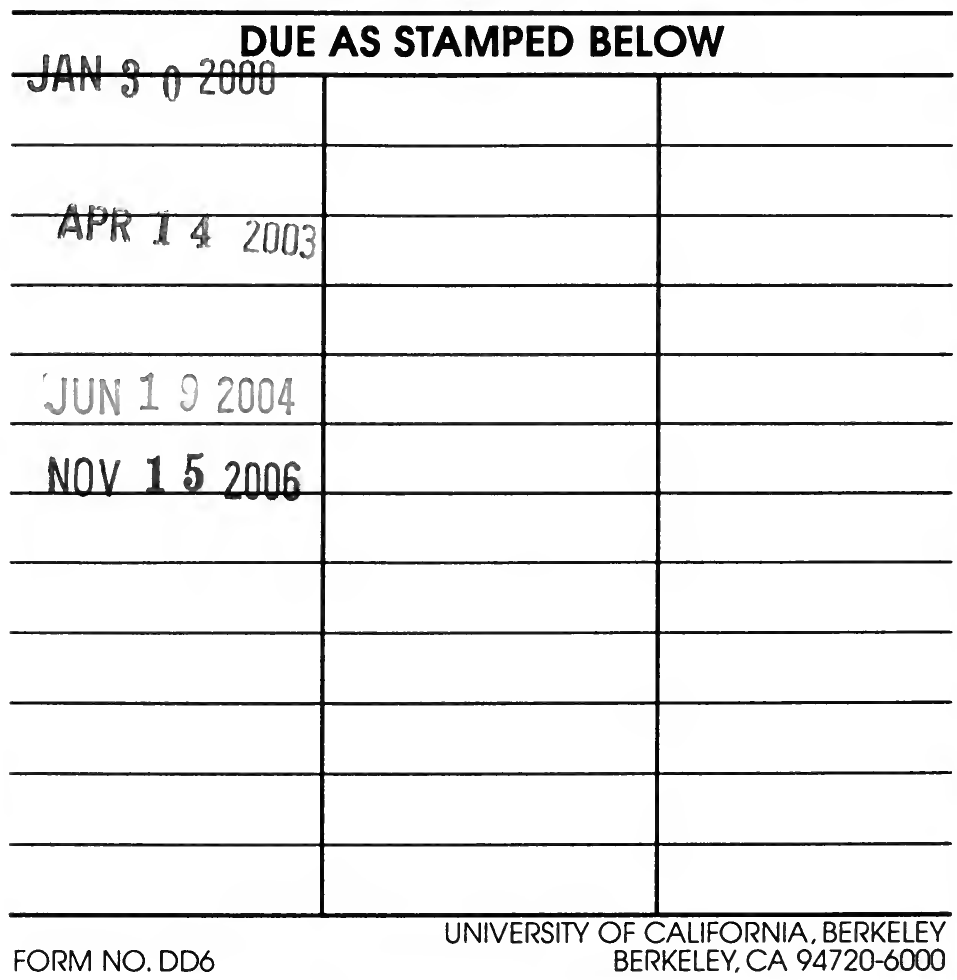




\section{YC129750}

a 
